\title{
INTESTINAL PUTREFACTION.
}

\section{INTRODUCTION.}

The decomposition of dead organic matter has been regarded as a source of disease from earliest times. Some of the pronouncements of the Mosaic Law are probably among the first public records in this connection. "Ye shall not "eat of anything that dieth of itself." (1) In the book of Isaiah, also, the mention of "putrefying sores" (2) would indicate that even, in those days, there existed a well-knit association between the process of putrefaction and disease. Hippocrates, in his treatise, "On Airs,

"Waters and Places" thus expressed his views concerning the production of certain diseases:-

"For water contributes much towards health. Such waters, "then as are marshy, stagnant, and belong to lakes, are "necessarily hot in summer, thick and have a strong smell, "since they have no current; but being constantly supplied "by rain water, and the sun heating them, they necessarily

"want their proper colour, are unwholesome and form bile;

"those who drink them have large and obstracted spleens,

"their bellies are hard, emaclated, and hot; such persons, "then, are voracious and thirsty, and in summer, dysenteries, "diarrhoeas and protracted quartan fevers frequently "sieze them." (3)

Adams refers to this treatise of Hippocrates "as containing "the oldest exposition which we possess of the opinions "entertained by an original and enlightened mind on many "Important questions connected with Public Hygiene and "Political Economy." (4) 
ProQuest Number: 13905355

All rights reserved

INFORMATION TO ALL USERS

The quality of this reproduction is dependent upon the quality of the copy submitted.

In the unlikely event that the author did not send a complete manuscript and there are missing pages, these will be noted. Also, if material had to be removed, a note will indicate the deletion.

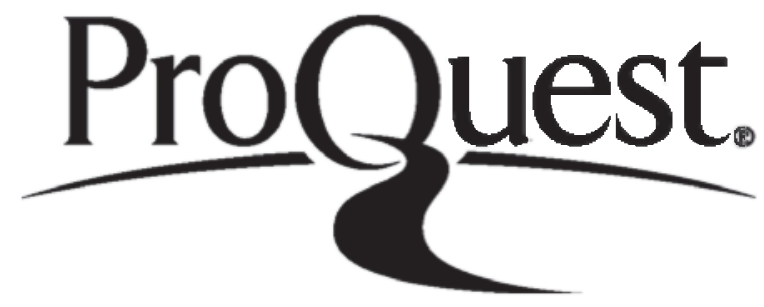

ProQuest 13905355

Published by ProQuest LLC (2019). Copyright of the Dissertation is held by the Author.

All rights reserved.

This work is protected against unauthorized copying under Title 17, United States Code Microform Edition (C) ProQuest LLC.

ProQuest LLC.

789 East Eisenhower Parkway

P.O. Box 1346

Ann Arbor, Ml $48106-1346$ 
In medieval times, the onsets of epidemics were frequently attributed to various organic or inorganic decompositions throughout the universe. Hecker (5), for example, gives the following description of the "Black Death" which was pandemic throughout Asia, Europe and Africa in the fourteenth century, "Never have naturalists discovered in the atmosphere "foreign elements, which, evident to the senses, and borne "by the winds, spread from land to land, carrying disease "over whole portions of the earth, as is recounted to have "taken place in the year 1348. German accounts say ex"pressly, that a thick, stinking mist advanced from the "East, and spread itself over Italy. In thousands of places "chasms were formed, from whence arose noxious vapours. "The consequences of innumerable floods contributed to the "same effect; vast river districts had been converted into "swamps; foul vapours arose everywhere, Increased by the "odour of putrefied locusts, which had never perhaps darkened "the sun in thicker swarms, and of countless corpses, which neven in the well regulated countries of Europe, they knew "not how to remore quickly enough out of the sight of the "IIving."

Various astral and telluric influences have also been held responsible for the spread of epidemics. Electrical phenomena in the air, heavenly bodies influencing our planet, exhalations from the earth or the formation of some unknown principle noxious to animal existence have all been suspected as cafífil agents of disease.

In the particular field of research represented by the study of decomposing organic matter, much work has been done both from the chemical and from the bacteriological standpoints, since the fourteenth century. Within this field of work, the subject of intestinal putrefaction is, perhaps, most readily approached by a study of the process of putrefaction/ 
putrefaction as it occurs in nature, apart from the lumen of the intestine and by a subsequent consideration of the vital conditions in the alimentary tract of man. Two distinct avenues thus invite survey before the final compound conception of intestinal putrefaction can be justifiably attained The subject has therefore been divided, for the purpose of this thesis, Into four sections, each of which is further subdivided, as follows:-

\section{SECTION I. \\ OBSERVATIONS UPON PUTREFACTION.}

A. Definition and Historical Evolution of the Yodern Conception of Patrefaction.

B. Historical Review of the Aromatic Amino-Acid Radicles. C. Review of Salkowski's Experiments upon the Production of

D. Experiments.

\section{SECTION II.}

THE INFLUENCE OF SUGARS ON PUTREFACTION.

A. Historical Review.

B. Review of Simnitzki's Experiments.

C. Experiments.

SECTION III.

OBSERVATIONS ON INTESTIIAL FUNCTION.

A. Previous Work including speolal Reviews of the Work of Corlette and Cathoart and Leathes.

B. Experiments.

SECTION IV.

INDICANURIA.

A. Historical Revion.

B. Experiments. 


\section{SECTION I.}

\section{OBSERVATIONS UPON PUTREFACTION.}

A. DEFIVITION AND HISTORICAI EVOLUTION OF THE MODERN CONCEPTION OF PUTREFACTION.

Bienstock (6) described putrefaction as representing the aggregate changes to which organic matter is subjected after death, consisting, at first, in a physical destruction of form and texture, followed by a chemical decomposition of its complex elements. He defined it further as "ls "fermentation anaerobe." Bienstock's conception thus visualised the physical, chemical and bacteriological changes which form essential parts of a process such as putrefaction and which incidentally represent the channels along which various investigators have worked. The physical changes in odour, colour, shape and consistence of tissues after death have long been familiar to the pathologist and to the medical jurist, under the name of colliquative putrefaction. The evolution of the chemical aspect of putrefaction is associated with an earlier origin than that of the bacteriological aspect although, within more recent times, almost simultaneous advances have been made in both directions.

Before the rise of moderm chemistry, all chemical changes, organic or inorganic, which exhibited the characters of effervescence, with liberation of heat and resultant alteration of properties, were classified under the term, fermentation Putrefaction was then regarded as a species of fermentation, in which there was a decomposition of animal or vegetable matter associated with the liberation of gases, with repulsive odours, and it was callod putrefactive fermentation. 
The earliest chemical investigations, pertaining to putrefaction, were apparently directed towards the discovery of gases arising from decomposing organic matter. Van Helmont $(7)$ in the seventeenth century was the first to demonstrate the presence of what he, himself, called "the wild invisible spirits which will not be pent up". (8) He described carbon dioxide under the name of "gas silvestre" and showed that it was formed in the burning of charcoal and in the fermentation of beer and wine. He also obtained an inflammable gas from the intestines and by the fermentation of dung, which he called "gas pingue". Until the midale of the seventeenth century, it was belleved that all gases arose from the burning of an oily sulphureous principle which was supposed to be contained in all combustible substances. This conception was simply an elaboration of the older sulphur-mercury theory of metals, of the thirteenth century in which the combustion of a metal was supposed to be due to the loss of its sulphureous constituent. In these early records, it is interesting to note the part assigned to sulphur as the essential component of combustible substances. Becher (9) in 1669, clarified the older ideas concerning volatile substances by regarding them as resulting from the disentegration of a burming substance. About this time also, Boyle (10) found a method of collecting gases over water and advanced knowledge by his discovery of the law describing the behaviour of gases under varying pressure. In 1702, stahl (11) extended Becher's views from which he evolved the Phlogiston Theory, wherein the name "phlogiaton" was given to the gaseous principle which was contained in all combustible bodies and which was given up to the air on combustion.l 
combustion. Cavendish (12) in 1766 found that "inflamrnable "air" (hydrogen) was evolved by the action of dilute sulphuric or hydrochloric acid on zinc. He also invented a method of storing gases over mercury, an idea which subsequently enabled Priestley to discover ammonia and other gases soluble in water. The composition of water and nitric acid represent two other important contributions of Cavendish to chemistry. Priestley (13) in 1771, discovered his ndephlo"gisticatec air" (oxygen) from mercurius calcinatus. He was the first to point out the similarity between combustion and vital processes such as respiration and putrefaction. Referring to the two latter processes he remarked:"They affect common air in the same manner in which all "noxious processes diminish air and make it noxious and "which agree in nothing but the emission of phlogiston." (13a) Ammonia, hydrochloric acia, nitrogen peroxide and sulphur dioxide were discovered by Priestley. While priority in discovery is usually given to Priestley, Scheele (14) working independently had 1solated oxygen under the name of "fire "air". In his "Experiments on Air and Fire" which were published in 1777, Scheele asoertained that common air was a mixture of two distinct elastic fluids, one of which alone was capable of supporting combustion and which he therefore called "empyreal alr"; the other which he found to be neither capable of maintaining combustion nor of being breathed he called "foul air". Oxygen and carbon dioxide were thus first aistinguished. In these experiments also, Sdheele gave the first account of sulphuretted hydrogen. He called this gas, stinking sulphureous air. (14a) He also, was the discoverer of lactose, lactic acia, oxalic, tartaric, malic, citric, gallic and benzoic acids and of chlorine, acetaldehyde and gljcerol. 
The subsequent investigations of Lavolsier (15) in the latter part of the eighteenth century gave birth to the moderm conception of oxidation and established the fact that vital processes in general were made up of a series of chemical reactions. Until this time, the combustion of organic substances and the calcination of metals were regarded as processes with a common cause, namely the emission of phlogiston by the burning or calcining body. Lavoisier revolutionised this conception. He held the opinion that nothing whatever left the bodies during burning or calcination but that they simply united with a portion of atmospheric air. A new chemical nomenclature founded upon this oxygen theory of combustion was published by Lavoisier and his associates in 1787 and this soon became the common language of chemists. Thomson (15a) states that besides his volume of Physical and Chemical Essays and his Elements of Chemistry, published in 1789, Iavoisier was the author of sixty memoirs which were published in the volumes of the Academy of Sciences from 1772 to 1788. Among these, the memoir "On the nature of the aeriform elastic Fluids which "are disengaged from certain animal substances in a state "of fermentation" is of interest. The following is Thomson's review of this memoir by Lavoisier:-

"He ( $15 \mathrm{~b})$ found that a quantity of recent human faeces, "amounting to about five cubic inches, when kept at a "temperature approaching to $60^{\circ}$ emitted, every day for a "month, about half a cubic inch of gas. This gas was a "mixture of eleven parts carbonic ac1d gas, and one part "of an inflammable gas, which burned with a blue flame, "and was therefore probably carbonic oxide. Five cuble minches of old human faeces kept in the same temperature, "during/ 
"during the first fifteen days emitted about a third of a "cublc inch of gas each day, and during each of the second "fifteen days, about one fourth of a cubic inch. This "gas was a mixture of thirty-eight volumes of carbonic acia "gas, and sixty-two volumes of a combustible gas, burning "with a blue flame, and probably carbonic oxide. Fresh "faeces do not effervesce with dilute sulphuric acid, but "oldmoist faeces do, and emit about eight times their volume "of carbonic acid gas. Quicklime, or caustic potash, mixed "with faeces, puts a stop to the erolution of gas, doubtless "by preventing all fermentation. During effervescence of "faecal matter, the air surrounding it, is deprived of a little "of its oxygen, probably in consequence of its combining with "the nascent inflammable gas which is slowly disengaged." This is probably one of the earliest records of a quantitative experiment on the gases arising from faeces.

Iavoisier's experiments served to show that the phenomena of the production of animal heat and the combustion of carbonaceous materials outside the body shared, in common, the chemical reactions characteristic of oxidation and reduction. These latter reactions were, therefore, found to form an essential part of the chemistry of such a process of combustion outside the body, as putrefaction. The work on gases from the time of Van Helmont to that of Lavolsier thus opened the way in both organic and inorganic chemistry to the more accurate analytical methods of the latter part of the nineteenth century and led to a more complete conception of decomposition processes in general. One of the next sources of information concerning the chemistry of putrefaction, appeared with the disoovery of amino-acids as dissociation products of albuminous substances.

According to Mann (16) the oldest known dissociation products of albumins are probably leucing discovered by 
Proust (17) in cheese in 1818 and called 'oxide caséeux', and glycocoll (or glycin) which was obtained by Braconnot (18) in 1820, after bolling gelatine and meat with sulphuric acid. Mann (19) states further that the name leucine (from $\lambda \varepsilon u k \sigma s,-b r i g h t$, clear, wh1te) was given to Proust's substance by Braconnot in 1820. The subsequent isolation of tyrosine by Iiebig and Hinterberger (20) in 1849 was followed by the discovery of many other amino-acids, thereby enhancing knowledge concerning the chemical nature of proteins and putrefactive media. Iiebig's work, in general, served to emphasise the important relationship which existed between living matter and chemical reactions. His interest in all chemical phenomena associated with the products of vital activity in both the animal and vegetable kingdoms led him to investigate many new organic suhstances such as melanin, wric acid and the aldehydes, and also to study the phenomena of fermentation and putrefaction. His explanation of these changes was, however, based on purely chemioal and mechanloal 1dess. He disregarded the organismal origin of these processes, subsequently demonstrated by Pasteur. Nith Ilebig, the purely chemical conception of putrefaction terminated. About 1839 when Iiebig was concerned with the study of putrefaction, the accumulation of evidence concerning putrefaction along bacteriological channels of investigation, rendered a coalescence with the Iindings of organic chemistry inevitable.

The presence of mieroorganisms was unknown until the serenteenth century when Ieeuwenhoek (2I), a Dutch Iens grinder, intent upon the perfecting of his lenses, discovered bacteria in a drop of stagnant rain water through a microscope of his own make. He was the first man to look upon a microsooplc field of living bacteria. He 
did not suspect their rôle in putrefaction or in disease but continued to record his bacteriological findings in different media. Ieeuwenhoek discovered the globular formation of yeast cells in beer and in other fermented Iiquids. He also discovered bacteria in the human mouth and in the intestines. The vast field of microscopic beings was thus, first openn to view by a man who was not primarily concerned with the casse of disease. It is noteworthy that Van Helmont and Leeuwenhoek, the ploneer discoverers respectively of gases and bacteria, working with aims which were, at that time, apparently widely different, should have made individual discoveries from the common mealum of the human intestine, within the same century and within the confines of their common native land. The work of Ieeuwenhoek focussed the attention of scientific men upon decomposing organic media as the habitat of bacteria and other minute forms of life. The chemical changes associated with such processes as putrefaction and fermentation were subsequently found to be due to these microorganisms. The linkage between the chemical and the bacteriological lines of research was established by Schwann (22) in 1838. About this time also Caignard Iatour (23) working independently, confirmed the same facts. In this connection Schwann's own words are of interest:-

"Those who do not as jet, admit the theory of fermentation "set forth by Caignard-Latour and myself, may take the "development of any simple cells, especially of the spores, "as an example. We have every conceivable proof that the "fermentation-granules are fungi. Their form is that of "fungi; in structure they, like them, consist of celle, "many of which enclose other young cells. Now, that these 
"fungl are the cause of fermentation, follows, first, "from the consistency of their occurrence during the "process; secondly, from the cessation of fermentation "under any influences by which they are known to be "destroyed, especially boiling heat, and arseniate of "potass, \&c.; and thirdly, because the principle which "excites the process of fermentation must be a substance "which is again generated and increased by the process "itself, a phenomenon which is met with only in living norganisms. Neither do I see how any further proof can "possibly be obtained otherwise than by chemical analysis, "unless it can be proved that the carbonic acid and alcohol "are formed only at the surface of the fung1." An introduction was thus given to the vital as compared with the purely chemical aspect of putrefaction. Thereafter, the biological aspect of fermentation and putrefaction developed rapidly.

In 1853, Cöhn (24) commenced his researches, founded on the earlier work of Ehrenberg (25) in 1830, and succeeded in establishing a classification of baoteria. At this stage, however, the definite link of association between putrefaction and disease was still unproved. Following In the wake of the preceding discoveries, Pasteur (26) in 1860, in his treatise upon "Génerations dites spontanées" confirmed and amplified the findings of Sohwann and Caignard Iatour and finally disproved the theory of spontaneous generation which had been supported by Iiebig and others. He showed that each process of putrefaction or fermentation was the result of the action of certain organisms upon certain organic media under certain conditions. (26a) He demonstrated, for example, the differential/ 
differential conditions under which sugar may undergo alcoholic, butyric, or lactic fermentation. The independent work of Pasteur and of cöhn finally proved that no putrefaction could take place without bacteria. Referring to the power of the infinitesmally small, Pasteur (27) expressed his views in the following words:"If microscopic beings were to disappear from our globe, "the surface of the earth would be encumbered with dead "organic matter and corpses of all kinds, animal and "vegetable. It is chiefly they who give to oxygen its "powers of combustion. Without them, Iife would become "Impossible because death would be incomplete."

In 1860 Pasteur thus showed that decompositi on processes such as fermentation and putrefaction were due to the presence of a living organism. Henceforth, putrefaction was regarded from a biochemical standpoint. The microorganism kas seen to be the activating agent and the amino-acid was regarded as the main object of attack. Varlous aspects of bacterial metabolism then invited investigation. The next step in the evolution of this biochemical conception of putrefaction was the formulation of a theory of fermentation based on enzyme action, by Berthelot and Traube who attributed all fermentations and putrefactions to the action of substances produced by regetable and bacterial cells. Such substances as diastese were distinguished as soluble or unorganised ferments in contra-distinction to living organisms like yeast which were called organised ferments. Berthelot (28) succeeded in separating from yeast a cell-free substance which inverted cane sugar. Traube (29) visualised putrefaction as being due to the agency of certain bacterial ferments endowed/ 
endowed with the power of reduction. Pasteur himself had not actually taken account of enzyme action in the formulation of his theory of fermentation. He believed that the chemical changes were the direct result of metabolic activity of the bacterial cell. The enzyme theory originated by Traube and Berthelot was finally established by Buchner (30) in 1897 when he separated from yeast a cell-free substance which fermented sugar with production of alcohol and carbon dioxide.

In 1863 the discovery of anaerobic organisms by Pasteur (31) marked a further stop in knowledge concerning putrefaction and opened the way to subsequent work on the conaltions governing anaerobic bacterial life. Pasteur discovered the anaerobic organisms to be a group distinct from all other bacteria. This group was found to consist of two types, the facultative anaerobes which could live either in the presence or absence of air and the obligatory anaerobes which were actually inhibited in growth and development by the presence of oxygen. Pasteur stated that decomposition was the specific work of the obligatory anaerobes. He believed that the rôle of the aerobio organisms in nature was complimentary to that of the anaerobes, in that the former removed oxygen and thus rendered various media anaerobic. The anaerobes were thus seen to follow in the wake of vital conditions in which oxygen was remored from the medium. As a result of his work upon beer and silk worm disease, in which he had demonstrated that a microorganism from the air was responsible for the chemical and pathological changes in each case, Pasteur offered the suggestion that disease in man and in animals was a malady due to an invading organism from/ 
from the air. On this basis, he formulated the germtheory of disease.

Iister (32) made the final link between putrefaction and disease when he applied the results of his own researches and those of Pasteur to the practice of surgery. "Permettez-mo1", wrote Lister to Pasteur in 1874, "de "saisir cette occasion de vous adresser mes plus cordiaux nremerciments pour m'avoir, par vos brillantes recherches, "démontré la vérité de la théorie des germes de putrefaction "et m'aroir ainsi donné le seul principe qui pût mener à "bonne fin le systime antiseptique."

The significance of Ilster's work in surgery gave further impetus to blochemistry and bacteriology. With regard to the biochemistry of putrefaction from 1875 onwards Pasteur's work was followed by the investigations of Nencki (33), Baumann (34), Brieger (35), E. \& H. Salkowski (36), (36a), Ellinger (37), and Ackermann (38). Special reference will be made later to the work of E. \& H. Salkowski.

With regard to the bacteriology of putrefaction, Pasteur's views concerning the association of anaerobic organisms with putrefaction were supported by the later observations of Nencki and Blenstock. Blenstock (39) found an organism which he called Bacillus Patreficus Coli in the intestine of man and regardeci 1t, at first as an aerobe. He discovered subsequently that it acted as an anaerobe. By excluding air from a fibrin medium, Blenstock found that he could always grow this obligatory anaeroble spore-forming organism. This organism regularly produced decomposition of fibrin and other albumen containing substances when oxygen was excluded and continued to do so, even when air was subsequently admitted provided that the layer of the liquid medium was more than 4 c.cms. deep./ 
deep. The existence of an organism endowed with the power of proteolysis was first demonstrated by Pasteur (40) in 1887. This organism he called "le vibron septique". Klein (4I) found an organism identical to Bienstock's B. Putrificus Coli in putrefying cadavers and called it B. Cadaveris. While it was recognised that all the anaerobes did not act in the same way as B. Putrificus Coli, Nencki (42) and his pupils demonstrated that the anthrax bacillus, the bacillus of maligmant oedema and clostidium foetidium did act in the same way as B. Putrifleus Coli causing proteolysis under anaerobic conditions. Bienstock's work led Tissier and Martelly (43), in 1902 , to investigate the essential part played by the obligatory anaerobes in the actual cleavage of the protein molecule. They carried out their observations on the putrefaction of ordinary butcher meat from both chemical and bacteriological standpoints since, it was their aim to study the process of decomposition occurring in nature, on mixed media. The work of Tissier and Martelly is of interest, since it provides a good conception of the process of putrefaction from both the chemical and bacteriological standpoints. In the introduction of their "Recherches "sur la Patréfaction de la Viande de Boucheri" these authors draw attention to the various phases of putrefaction, in which connection they quote the words of Macé, which give a very concise picture of the sequence of biochemical events:-

"Tout d'abord apparaissent le B. subtilis, le B. mesenter"icus, le B. termo, on ne pero̧olt qu'une odeur plutôt "fade, ce n'est pas encore la putréfaction. Un ou deax "jours après, ces espèces ont cédé le pas à d'autres oì "dominent/ 
"dominent le B. fluorescens liquefaciens, le B. fluorescens "putidus, le B. Violaceus: c'est une seconde phase du "phénomène. Quelques jours après, l'odeur est nettement "putride; c'est alors, troisième phase, qu'apparaissent "les Proteus valgaris et mirabilis qui dominent bientôt "et deviennent envahissants."

Tissier and Martelly regarded putrefaction as a process characterised by progressive stages of well defined chemical and bacteriological changes, and they approached their researches on meat in the light of this conception. As a result of their work they recognised two phases in the putrefaction of meat.

(1)"Phase des ferments mixtes protëolytiques and peptolytiques"during which, sugar is decomposed and albumen attacked. The further decomposition of proteins thus produced, provides the ammonia necessary to neutralise the medium.

(2)" Phase des ferments purs protéolytiques et peptéolytiques" which complete the decomposition of albumen and its ultimate derivatives.

About this time Bmmerling (44) had claimed that certain facultative aerobic organisms such as staphlococcus pyogenes and streptococcus pyogenes were capable of inaugurating putrefactive changes in proteins. In order to dispel this idea and to finally establish the fact that the ordinary facultative aerobes were incapable of initiating putrefaction in egg and meat media, Rettger (45), In 1906, conducted a series of careful experiments. He took 14 B. coll strains isolated from 12 different samples of stools and inoculated these into various ege and meat mixtures. In not one of these did he observe any visible changes/ 
changes after $3-4$ weeks inoculation at $37^{\circ} \mathrm{C}$. In the preparation of his mecila, Rettger adopted most extensive precautions to exclude possible anaerobes. The floors of his laboratory were oiled, table tops and shelves were washed with corrosive sublimate and finally the flasks, stoppers and delivery tubes were sterilised. "It required fully a joar's constant work", wrote Rettger, "and the preparation and final analyses of some fifty "culture flasks inoculated with different facultative "aerobes, particularly members of the colon bacillus "group."

He succeded in demonstrating that facultative aerobes could not cause putrefaction. Rettger attributed Emmerling's claims of having brought out putrefaction of egg albumen and blood fibrin with staphlococcus pyogenes and streptococcus pyogenes, as belng due to contamination by omnipresent aneerobes. While more recent work has demonstrated the aeroble deoomposition of rarious amino-acids in selected media, the start was thus made in the elucidation of the specific parts played by various organisms in putrefaction.

At the beginning of the present century then, the subject of putrefaction had been approached through various channels. Many of the substances produced during the process of putrefaction had been recognised and isolated, many of the organisms apparently responsible for the production of these substances had also been discorered, a distinction had been made between the conditions governing aerobic and anaerobic bacterial life, the phenomena of bacterial enzyme aotion had been established and the proteolytic powers of anaerobic organisms had been fairly/ 
fairly accurately assessed. Ifore recently, during the Great War, the significance of the anaerobes was fully appreciated when vibron septique, B. Welchil, B. oedematicus and B.fellox, B.sporogenes, and B. histolyticus were found in wounds. The production of acids, by some of these organisms was advanced to account for certain clinical features in gas gangrene infection. In 1917, Wolf and Telfer (46) investigated the actd production of $B$. Nelchil and $B$. sporogenes in milk and Elucose-peptone media and found that large quantities of volatile acids were produced.

Since 1917, Raistrick (47) has investigated various types of chemical change produced by bacteria and his findings have done much to clarify the present conception of the mechenism of putrefaction. According to Raistrick (47a) "By far the most common of all the chemical changes induced "in amino-acids by bacterial action is simple decarboxylation, "i.e. the production of an amine from an amino-acid by the "loss of $\mathrm{CO}_{2}$.

" $\quad \mathrm{R} \cdot \mathrm{CH}_{2} \cdot \mathrm{CH}\left(\mathrm{NH}_{2}\right) \cdot \mathrm{COOH} \rightarrow \mathrm{R} \cdot \mathrm{CH} \cdot \mathrm{CH}_{2} \cdot \mathrm{NH}_{2}+\mathrm{CO}_{2} \cdot n$ Raistrick regards the other type of change brought about by bacteria and known as ideaminisation' (1.e. the production of a saturated acid and ammonia from the amino acid) as being of less interest.

$\mathrm{nR} \cdot \mathrm{CH}_{2} \cdot \mathrm{CH}\left(\mathrm{NH}_{2}\right) \cdot \mathrm{COOH}+\mathrm{H}_{2} \cdot-\mathrm{R} \cdot \mathrm{CH}_{2} \cdot \mathrm{CH}_{2} \cdot \mathrm{COOH}+\mathrm{NH}_{3} \cdot n$ This latter type of reaction is associated with a process of hydrogenation or reduction. Stephenson (48) recognises, In adition to the process of decarboxylation, the following further types of deaminisation:"Hydrolytic deamination with formation of the hydroxy acid, $" \quad \mathrm{R} . \mathrm{CHNH}{ }_{2} \cdot \mathrm{COOH}-\mathrm{NH}_{3}+\mathrm{H}_{2} \mathrm{O} \rightarrow \mathrm{R} \cdot \mathrm{CHOH} \cdot \mathrm{COOH}$.

"Hydrolytic deamination and decarboxylation with formation "of the alcohol,

$n \quad \mathrm{R} . \mathrm{CHIHH}_{2} \cdot \mathrm{COOH}-\mathrm{HH}_{3}-\mathrm{CO}_{2}+\mathrm{H}_{2} \mathrm{O} \rightarrow \mathrm{R}_{2} \mathrm{CH}_{2} \mathrm{OH}$. 
"Reductive deamination with formation of the saturated acid, " R. $\mathrm{CHNH}_{2} \cdot \mathrm{COOH}-\mathrm{NH}_{3}+\mathrm{H}_{2} \rightarrow \mathrm{R} \cdot \mathrm{CH}_{2} \cdot \mathrm{COOH}$

"Reductive deamination and decarboxylation with formation "of the hydrocarbon,

" $\quad \mathrm{R} \cdot \mathrm{CHNH}_{2} \cdot \mathrm{COOH}-\mathrm{NH}_{3}-\mathrm{CO}_{2}+\mathrm{H}_{2}=\mathrm{R} \cdot \mathrm{CH}_{3}$.

"Desaturation at the $\alpha-B-1$ inkage with formation of the "unsaturated acid,

" $\quad \mathrm{R} \cdot \mathrm{CH}_{2} \cdot \mathrm{CHNH}_{2} \cdot \mathrm{COOH}-\mathrm{NH}_{3}-\mathrm{R} \cdot \mathrm{CH}: \mathrm{CH} \cdot \mathrm{COOH}$.

"Oxidative breakdown to compounds having fewer carbon atoms, $n \quad \mathrm{R} \cdot \mathrm{CH}_{2} \cdot \mathrm{CHCH}_{2} \cdot \mathrm{COOH}-\mathrm{NH}_{3}-\mathrm{CO}_{2}+\mathrm{O}_{2}=\mathrm{R} \cdot \mathrm{CH}_{2} \cdot \mathrm{COOH} \cdot n$

On the basis of these views, it is seen that chemical change, originating in an amino-acid, may develop along one or other of the routes mentioned. The following table, suggested by Raistrick, gives the order in which the two main lines of change, decarboxylation and deaminisation, are likely to occur:-

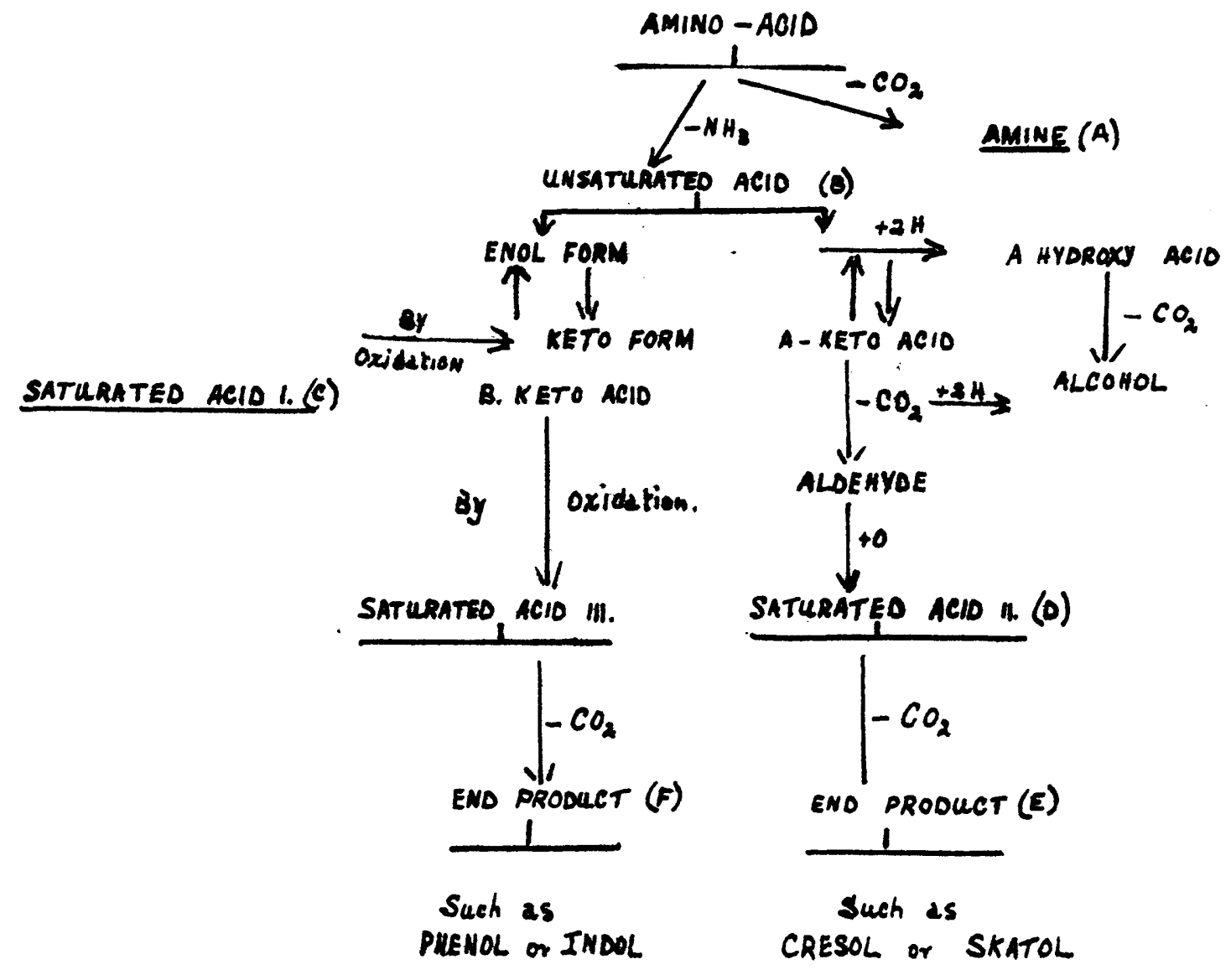


Cole (49) has given examples of substances corresponding to the types A. to F. of the above scheme, which are formed by bacterial decomposition of the amino-acids tryptophan, tyrosine, and histidine. Thus when tryptophan is decarboxylated by the witharawal of carbon dioxide as a first step, in its decomposition by organisms, the amine indol-ethyl-amine is formed. When, on the other hand, tryptophan is gradually oxidised by bacterial activity, ammonia, the saturated fatty acids, indol-propionic-acid and indol-acetic-acid, carbon dioxide, skatol and indol are formed. When tyrosine is decarboxylated the amine P-oxyphenyl-amine or tyramine is formed. When tyrosine is oxidised, ammonia, the saturated fatty acids, P-oxy-phenyl propionic acid, P-oxy-phenyl acetic acid, carbon dioxide, P. cresol and phenol are formed. When histidine is decarboxylated the amine B-iminazol-ethyl-amine or histamine is formed and when oxidised, ammonia, the unsaturated latty acid, iminazol acrylic acid or molcanic acid, the saturated fatty acid, iminazol propionic acid and carbon dioxide are formed.

Many other examples of similar changes in different amino-acids have been cited by Dakin (50), Raistrick, and Stephenson (5I). Cystine, leucine, phenylalanine, proline, lysine, aspartic acid, ornithine, glycine and alanine and creatinine have all been found to possess the two potential routes of chemical reaction, on bacterial decomposition.

As far as can be ascertained, this represents the essence of the biochemical conception of putrefaction, at the present time. These possible lines of clearage of amino-acid radicles represent a sphere of particular interest, not only from the biochemical and bacteriological aspects but also from the clinical standpoint, in view of the association 
of disease with products of bacterial activity. The line of change which may be designated as the $\mathrm{CO}_{2} \rightarrow$ amine routen is associated with the production of toxic substances whereas the "NH 3 - saturated acid route" is associated with the formation of interme iate and end-products which are regarded by some as being non-toxic.

At this point,it is necessary to consider the extent of the field of study which has been entered and to visualise the number of amino-aoids already discovered, each with a potential change along one of sereral routes and each open to attack by a large variety of organisms, aerobic and anaerobic.

Wile the aggregate changes characteristic of putrefaction must be kept in view, observation of one of the component lines of change may provide a clearer conception of the process as a whole. The selection, therefore, of one channel of observation out of the many already charted has been deemed advisable. The aromatic, the fatty acid and the sulphar containing amino-acid radicles and their derivatives represent the more important substances associated with the bacterial decomposition of proteins. In view of their preponderance in putrefactive processes, some of the substances derived from the aromatic amino-acid radicles have been selected for stady in this thesis. 


\section{BIBLIOGRAPHY. (SECTION I.A)}

(1) Deuteronomy. 14, 21.

(2) Isaiah. I, 6 .

(3) ADAMS, F.: 'The Genuine Works of Hippocrates.' 1849, 1. 195. London: Sydenham Society.

$$
\text { Ibid., } 183 .
$$

(5) HECKER, J.F.C. The Ipidemios of the Midale Ages. 1854 , 14. London: Sydenham Society.

(6) BIENSTOCK, B.: 'Recherches sur la Putréfaction.' Annales de I'Institut Pasteur. 1899, xiil, 854-864.

(7) VAN HELMONT, J.B.: Ortus medicinae Amstelodami. 1652 and $1667,253$.

(8) HOEFER, F.: Histoire de la Chimie. 1869, 11, 139.

(9) BECHER, J.J.: Acta Laboratorrl Chymic1 Monacensis, seu Physica Subterrania. 1669, 1, 5, 100.

(10) BOYLE, R.: Boyle's Works. Thomas Birch, B.A. 1744. Nova Experimenta Pneumatica Respirationem Spectantia. 1675 .

(11) STAHL, G.E.: Physiea Subterrania. 1702. Specimen Becherionum. 1702 .

(12) CAVWDISH, H.: 'Experiments on Factitious Air.' Philisophical Transactions of the Royal Society. $1784,1785,17,66$. 
(13) PRIESTIEY, J.: Experiments and Observations on different kinds of Air. 1774.

Dictionary of National Biography. 1896, xlvi, 357-371. A.Gordon. 371-376. P.J.Hertog.

(13a) PRIESTIEY, J.: Chemistry to the Time of Dalton. 1925,

89. BY. E.T. HOLMYARD. LoroOM: Oxmord uMivensity pefss.

(14) SCHEEIE, K.W.: Chemical Observations and Experiments on $A 1 r$ and Fire. 1777.

(14a) SCHEETE, Kall: History of Chemistry. T.Thoms on. 1831, ii, 69. Iondon: Henry Corburn \& Richard Bentıez.

(15) IAVOISIER, A.I.: Experiences sur la réspiration des animaux et sur les changements d̀ l'air en passant par leur peumon. Traité Élémentaire de Chimie présenté dans un Ordre Nouveau et d'après les Dé convertes Modernes. 1789 .

(15a) THOMSOI, T.: The History of Chemistry. 1831, 11,69. Iondon: Henry Colburm \& Richard Bentlej.

(15a) THONSON, T.: The Eistory of Chemistry. 1831, 11, 94. London: Henry Colburn \& Richard Bentley.

(16) MaNN, G.: Chemistry of the Proteids. 1906, 18. Iondon: Macmillan \& Co.

(17) PROUST, M.: Ann. de Chimie et de Physique. 1818, x, 40.

(18) BRACONNOT, H.: Ibid. ( xi11, 113 . 
(19) MANT, G.: Chemistry of the Proteids. 1906, 19. Iondon: Macmillan \& Co.

(20) HINTERBLRGWR, F.: Ilebeig's Annalen, 1849, Ixxi, 70.

(21) IEEUWENHOEK, A.: Anatomia Seu interiora remum. 1687.

(22) SCHWANN, T.: Microscopical Researches into the Accordance in the Structure and arowth of Animals and Plante. 1847, 197. Lond on: Sydenham society.

(23) CAIGNARD IATOUR, : Mémoire sur la Fermentation Vineuse, présénte a l'academie le 13 juin 1937.' Annales de Chemie at de Physique. 1838, Ixvi11, $206-221$.

(24) COHN, F.0.: Beitr. zur Biol, der Pfl. 1872, Het.11.

(25) EHRENBERG, Chr. - G.: Die Infersionsthierchan als vollkommene Organismen. 1838, Iiepzig, fol. ( 64 col. Taf.) Vibrio. $77-83$.

(26) PASTEUR, I.: 'Génération d1tes spontanées. 1860.' Ourres de Pasteur. 11, 186 - 656 .

(26a) PASTEUR, I.: 'Hémoir ur la termentation alooolique.' Ann. Chim. et Physique, 3e. sērie, 58. 323.

(27) PASTEUR, I.: Ilfe of Pasteur by René Vallery-Radot. 1. 101. Iondon: Constable \& Co. Itd.

(28) BERTHELOT, M.: 'Sur la fermentation glucosique du sucre du canne. 1860.' Compt. Rend. I, 980.

(29) TRAUBE, Y.: 'Die Chemische Theorie der Fermentwiricum, und der Chemismas der Respiration. 1877." St. x, 1984 . 
(30) BUCHNER, E.: Alkoholische Gärung ohne Hefezelln. 1897, 1.. Ber. $\mathrm{xxx}, 117$.

(31) PASTEUR, I.: 'Expériences et vous nouvelles sur la nature des fermentations." Compt. Rend. lif, 1260. 'Nouvelle exemple de fermentation déterminée par des animalcules infusoires pouvant vivre sans gaz oxygène libre, et en dehors de tout contact arec l'alr de l'atmosphère.' Compt. Rend. Ir1, 416. Also Oeurres de Pasteur, Paris. 1922, T.i1, 159 .

(32) IISTrR, : Iife of Lister by Sir Rickman John Godlee, Bt., 275. Iondon: Macmillan \& Co. Itd.

(33) NarCKI, No: Ueber die Harnfarbstoffe ans der Indigogroupe und uber die Pankreasverdauung.' Ber. d. deutsch. Chem. Gesellsch. 1875, V111, 886. 'Ueber das Indol.' Ibid. 1875, vii1, 722.

(34) BAULANI, E.: Ber. 1879, xi1, 1450.

Ber. 1880, x111, 279 .

ze1t. f. physiol. Chem. 1800, ir, 304.

(35) BRIEGER, I.: 'Ueber die aromatischen Produkte ans E1weisa. Ze1t. 1. physiol. Chem. 1879, xi1, 134 , et seq.

(36) SAIKOWSKI, E. \& H. Ber. 1883, xv1, 1191. 
(36a) SATHOWSKI, E.:'Zur Kenntniss du Eiweissfaulniss, 1: Ueber die Bildung des Indols und Skatols, nach geminscheftlich mit $H$. Salkowski in Hinster anaestellten Versuchen! Zeit. $f$. physiol. Chem. 1883-4, viii, 417-466.

(37) ELIIYGER, A.: Zeit. 1. physiol. Chem. 1900, xxix, 334.

(38) ACKERMANN, D.: Zeit. f. physiol. Chem. 1910, 1xiv, 504.

(39) BIENSTOCK, B.: 'Ueber die Bakterien der Foeces.' Ze1t. f. Klin Med. 1884, xiii.

(40) PASTEUR, I.: Bull. Acad. de ied. 1877, 781. Ibid. 1881, 176 .

(41) KLEIN, : Centralbl. f. Bakt., etc. 1889, 25, 1 Abt. 278.

(42) NENCKI, M•: Sitzungaber. U. Kaiserlich Lcad. d. Mein., Wein. 1899.

(43) TISSIER, H. \& MN. MARTEIIY: 'Recherches sur la Putréfaction de la Viande de Boucheri." Annales de l'Institat Pasteur. 1902, 865.

(44) EMALRIING, 0.: Ber. d. Deutsch Chem. Geselsch. 1896, xaxix, $2721-2726$.

(45) RETTGER, I.F.: 'Studies on Putrefaction'. Jour. of B101. Chem. 1906-7, i1, 72.

(46) WOLE, C.G.I. \& S.V.TELFER: Contributions to the B10chemistry of Pathogenic Anaerobes. 1i. The Acia Production of Bacillus Welchil (B. perfringens) and Bacillus sporogenes (Metohnikoft). BueH4M. Took, X1. 5.4. $19 / 7$ 
(47) RAISTRICK, H.: On a new type of chemical change produced by bacteria. The conversion of histidine into urocinic acid by bacteria of the colityphosus Eroup. Biochem. Jour. xi, 71. 19/7. Studies on the cycloclastic power of bacteria. Part II. A quantative study of the aerobic decomposition of tryptophan and tyrosine by bacteria with A.B.Clark. Biochem. Jour. xv, 76. $192 \%$

(47a) RAISTRICK, H.: On a new type of chemical change produced by bacteria. The conversion of histidine into urocanic acid by bacteria of the dolttyphosus group. Biochem. Jour. xi, 71. 19/7.

(48) STEPHENSON, M.: Bacterial Metabolism. 1930, 190. London: Iongmans, Green \& Co.

(49) COLE, S.W.: Practical Paysococieal Chemistry: CAMBRIDEE: W. HEFFEP SOY.

(50) DAKIN, H.D.: Oxilations \& Reductions in the animal Body. 1912, 79. Iondon: Iongmans, Green \& Co.

(51) STEPHEMSON, M.: Bacterial Metabolism. 1930, 191-201. Iondon: Iongmens, Green Co. 


\section{SECTION I.}

\section{OBSERVATIONS UPON PUTREFACTION.}

\section{B. HISTORICAL REVIEW OF THE AROMATIC AMINO-ACID RADICIES.}

The aromatic amino-acid radicles include, tryptophan, tyrosine, and phenylalanine and their derivatives. The two former substances belong to that portion of the protein molectile which is readily dissociated by the action of acids and ferments; the latter amino-acid belongs to that portion of the molecule which exhibits a greater degree of resistance to decomposition. Schützenberger and Fühne first pointed. out those features of varying degrees of dissociability. Schützenberger (1) examined the products of decomposition of albuminous substances after bolling with sulphuric acid and after digestion in closed vessels at high temperature with barium hydrate. Kühne (2), on the other hand, examined products of albumen decomposition by trypsin.$\wedge$ Independent observations of these two investigators did much to formalato a conception of the lines upon which albumen decomposition proceeds under the influence of hydrolytic agents. Some facts concerning tryptophan and tyrosine are worthy of consideration. Pryptophan.

The name" tryptophan"was first suggested by Neumeister (3) as indicating the origin of this substance in the decompositi on

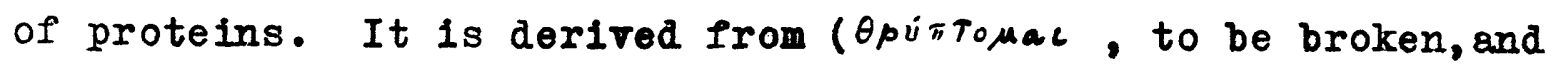
daivw, to bring to light). Tryptophan was discovered in 1831 by Tiedemann and Gmelin (4) in the pancreatic juice of a dog, in which it declared its presence by a violet red colouration with chlorine or bromine. These authors assumed that this reaction was characteristic of pancreatic secretion. Claude Bermard (5), however, in 1856, found that the reaction was present only in pancreatic julce which had been kept for some time, that it was not given by fresh secretion and that it 
ceased with the onset of putrefaction. He found further, that if the putrefying juice, in which the reaction could no longer be obtained were precipitated with lead acetate, the filtrate freed from lead by dilute sulphuric acid and the second filtrate treated with nitric acid containing nitrous acid, a red colour was produced, which he belleved was due to the reappearance of the same body which had caused the original colouration with chlorine. Kühne (6) in 1865 , disproved this view by shewing that the nitric and nitrous acid reactions were due to indol. Kähne's work established the fact that tryptophan, which, at this time, was only recognisable by its colour reactions, was not only one of the products of pancreatic digestion of proteins but was a constant product of albumen decomposition. The constitution of tryptophan was actually unknown until 1902, when Hopkins and Cole ( 7 ) isolated it in a pure state and recognised it as being of the nature of indol-amino-propionic acid or 1ts isomer skatol-amino-acetic acid. They prored what had already been suggested, although not claimed by the work of Kïhne, that tryptophan was the mother substance of Indol. Tryptophan has been found to give colour reactions with a great variety of substances and has been regarded as a pigment containing amino-acid.

The work of Salkowski, Henck1, and Hopkins and Cole established the fact that when tryptophan was subjected to bacterial decomposition in the alimentary tract or elsewhere, the following compounds were formed, indol-B-propionic acid, indol-Bracetio ac1d, skatol and indol: 
30.

IMDOL-B-PROPIOYIC ACID.

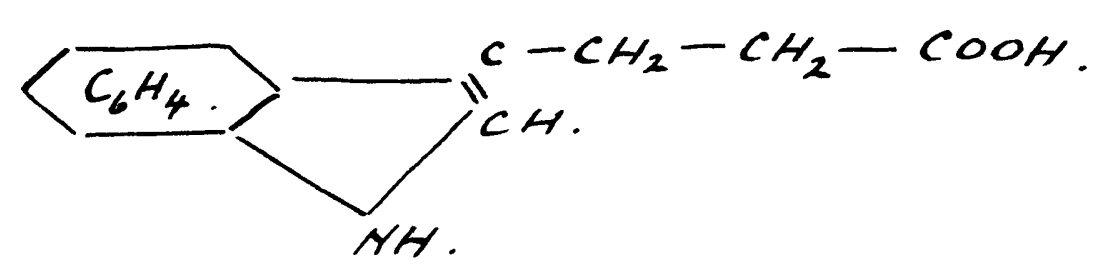

By LOSS of $\mathrm{CH}_{2}$

IMDOL-B-ACETIC ACID

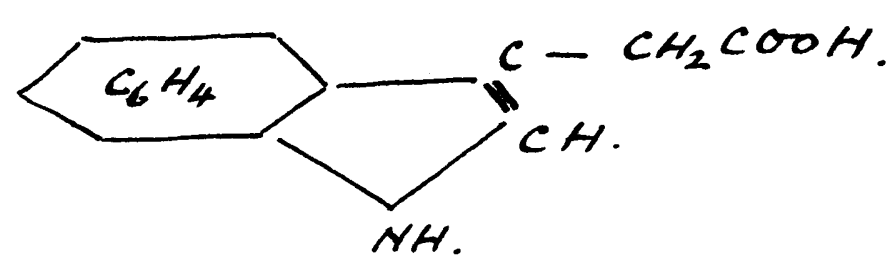

IMDOL- $\beta$-CARBOXYLIC ACID.

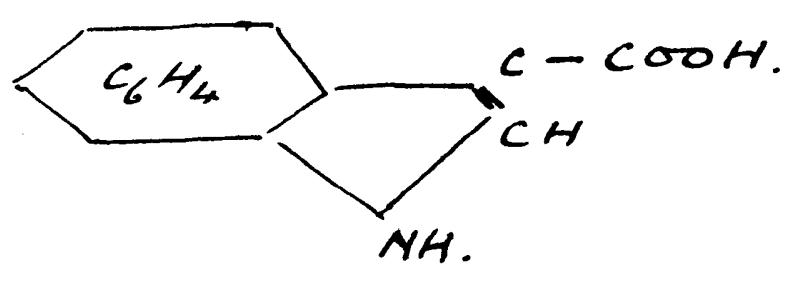

SKATOL.

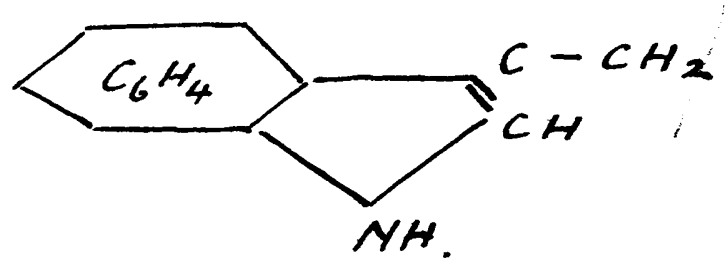

3

IMDOL

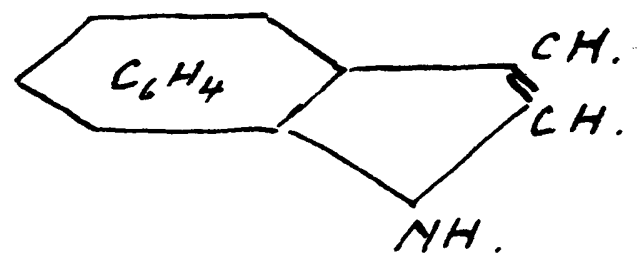

While/ 
While more interest is attachable to the end-products of tryptophan decomposition, and especially to indol, a few points concerning the intermediate substances may be mentioned.

With regard to indol-B-propionic acid, Dakin, (8) has stated that its formation from tryptophan has been effected by anarrobic organisms only. It has been found in the intestinal contents of man.

The characteristic feature of indol-B-acetic acid has been found to be 1 ts comparative resistance to change in the animal body. Salkorski has found it frequently in human urine.

Iltle work has been done in connection with indol-Bcarboxylic acid. It has been found to be a fairly common ingreatent in human urine.

The work skatol is derived from (okarós, meaning dung). This substance has also been designated B-methjl-indol. It was first isolated by Brieger (9) from faeces in Hencki's laboratory in 1877. Henck1 (10) found it later in the products of pancreatic putrefaetion. The work of B. \& H. Salkowski established the fact that a close relationship existed between skatol and indol. Gangee (11) has quoted the words of these authors as follows:"That skatol and Indol can replace each other, seeing that "In the albuminous molecule skatol does not form one definite "fraction and indol another, but both substances take their "origin in a common mother-substance which exists in the "proteld; this substance, according to olrcumstances, yields "at one time indol in preponderating quantity, and at another "time skatol, so that free skatol may be almost absent." B. \& H. Salkowski assumed the existence of a skatol-producing and of an indol-producing microorganism. The oharacteristio 
faecal odour of skatol, its.greater volubility and its higher melting point were found to be distinguishing features from indol. In 1907 , Herter (12) stated that skatol was formed under entirely different conditions from indol and that B. Coll did not produce skatol.

Indol was first discovered by Baeyer (13) by the reduction of indigo through distillation with zinc dust. It was through its original association with indigo that indol received its name. The prefix "ind" was derived from the word" indigo" which literally means 'substance from 'India'. The affix "ol" was derived from the Iatin, oleum an 01l. It is apparently not of the same derivation as the affix in "alcohol." The word" indol "means an indigo oil or an oll associated with a pigment containing substance. In 1875 Nenok1 (14) and Kühne (15) identifled indol among the products of protein decomposition, and also among the fusion-products of proteins and caustic alkalies.

In 1884 E. Salkowski (16) carried out a series of experiments on the quantitatire jield of indol and skatol from the putrefaction of horse flesh, blood fibrin, peptone and muscle fibrin, from whioh he succeeded in ascertaining many definite properties of those end-produets. In addition to his raluable quantitatire findings and his definition of the properties of indol, to which reference will be made later, Salrowski's chief contribution to the chemical conception of putrefaction lay in his deduction, from the time incidence of indol, that the chemical changes were effected by the gradual dissociation of intermediate products rather than by the direct formation of end-produota. This latter point was finally confirmed by Hopkins and Cole in 1902 when they found indol to be a derivative of tryptophan. 


\section{Tyrosine.}

As previously mentioned the amino-acid tyrosine was one of the first of the protein dissociation products to be isolated by Ilebig and Hinterberger. Since these investigators discovered this crystalline substance by fusing cheese with caustic potash, they called it tyrosine" (fromrupós, meaning cheese). In the various media in which it has been found, the presence of tyrosine has frequently been associated with that of the amino-acid leucine. Virchow (17) in 1854, found tyrosine and leucine as constituents of the pancreas in man and in the lower animals. In 1855, Frerioh (18) detected tyrosine and leucine in the liver, blood, and urine in cases of acute yellow atrophy and acute phosphorous poisoning. These two amino-acids were recognised again in 1867 by Kühne (19) as products of tryptic digestion of fibrin. Kühne also pointed out that the pancreas, soon after death, contained much larger quantities of tyrosine and leucine than were present at the time of death. The researches of Kühne and his pupil Radziejewsky (20) finally established the fact that the pancreas contained no tyrosine during l1fe. It was assumed therefore that the post-mortem presence of tyrosine in the pancreas was due to auto-digestion of the gland substance.

The influence of bacterial action upon tyrosine was first investigated by Nencki (2I) in 1874. He found that when this amino-acid was subjected to decomposition by the anaerobic organism, Bacillus Rauschbrand, oxyphenyl-acetic acid, exyphenyl-propionlc-acid; cresol, and phenol were produced. In 1880 Baumann (22) demonstrated the presence of the same substances when tyrosine was decomposed by putrefying/ 
34.

putrefying pancreas. The accumulation of evidence finally indicated that when tyrosine underwent bacterial decomposition in the alimentary tract or elsewhere the following compounds were formed:-

P.OXYPHEMYL PROPIOMIC ACID.<smiles>O=C(O)CCCCCCCCCCO</smiles>

BY OXIDATION AND LOSS OF $\mathrm{CH}_{2}$ P-OXYPHEMYL ACETIC ACID.

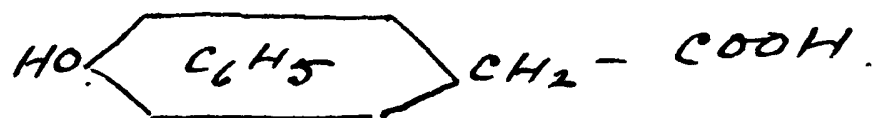

P -CRESOL<smiles></smiles>

PHENOL.

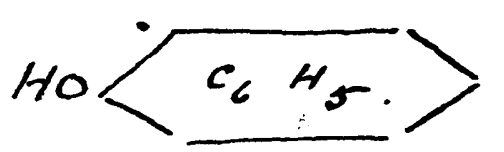

The conception of the way in which these products of decomposition are related to one another was largely based on the work of Barman. (23)

From the above, it is seen that the chemical mechanism of bacterial decomposition of tyrosine is similar to that of tryptophan. A few points concerning the derivatives of tyrosine are worthy of mention.

According/ 
According to E. \& H. Salkowski P-oxyphenyl-propionic acid has been formed from tyrosine by reduction both in the nucleus and in the side-chain. Traetta Mosca (24) described an organism of the pyocyaneus type, capable of effecting the complete decomposition of this aminoacid in an inorganic medium with the intermediate formation of $\mathrm{P}$-hydroxyphenol-propionic acid, benzolc acid and benzene.

P-oxyphenyl-acetic acid although readily dissociated by organisms has been found to be very resistant to change within the animal body. In this latter respect it resembled indol-B-acetic acid. It was first found by E. \& H. Salkowski (25) as a product of the putrefaction of wool and various albuminous substances. As previously mentioned, Baumann recognised this acid among the products of putrefaction initiated by decomposing pancreas. He also found it in the urine after injection of tyrosine into the blood and in acute yellow atrophy and phosphorus poisoning.

P-cresol was discovered in 1879 by Baumann and Brieger (26) among the products of putrefaction of proteins. In the same year Neyl (27), under the direction of Baumann, extracted P-cresol and phenol from the putrefaction of tyrosine.

Phenol was not known to be associated with the process of putrefaction unt1l 1874, when Nencki isolated it from the bacterial decomposition of tyrosine. Prior to that time Runge (28) had been of the first workers in 1834, to describe phenol as one of the numerous constituents of coal tar, from which it was derived by distillation. It was also known to be formed by the action of heat upon salicylic acid. 
Following upon Nencki's discovery, Baumann (29), in 1877, found phenol among the products of pancreatic putrefaction. In the same year Brieger (30) demonstrated it in the faeces. Salkowskl found that tissues which were rich in tyrosine, such as horm substances, nails and hairs yielded much more phenol than flesh on putrefaction.

From among these aromatic derivatives, indol has been selected for special consideration in this thesis, in view of the fact that it is a substance which can be pursued clinically, in so far as it nay be absorbed from the lumen of the bowel and excreted in the urine as indican. 


\section{BIBIIOGRAPHY (SECTION I.B.)}

(1) SGÜTZENBERGRR, M.P.: 'Recherches sur I'albumine et les matieres albuminoides.' Bulletin de la Societe Chemique de Paris. Tomes (23), 161, $193,216,242,385,433 .(24), 2$ and 145.

(2) KÜHNE, W.: Verhandl, a. Heidelberger naturhist-medizin. Vereins, N.F.I. 236. 1876. Ze1t. f. Biol. 1883, xix, 159. Tbia. 1885, xx11, 423 .

(3) NEUMISTER, R.: 'Zur Physiologie der Elweissresorption und zur Lehre von den Peptonen.' Zeit. fur Biologie. 1890, xxvi1, 309-373.

(4) TIEDlianN, F. and I. GusiIN: 'Die Verdauung nach Versuchen. Heldelberg'. 1831.

(4a) OSBORNE, T.B. \& I.F.HARRIS: The tryptophane Reaction of Various Proteins.' Jour. of the Amer. Chem. Society. 1903, xxv, No.8.

(5) BERHARD, C: 'Mémoire sur le Pancréas.' Comptes Rendus, Supplément, 1. 1856, 403-409.

(6) KUHNE, W.: 'Ueber Indol aus Eiweiss.' Ber. d. deutsch chem, Gesellsch. 1865, Vi11, 206.

(7) HOPKINS, F.G. \& S.T.COIE: Jour. of Physiol. 1900, xxvi1, 418. Ib1d. 1902, $\mathrm{xxix}, 451$.

(8) DAKII, H.D.: Oxidations and Reductions in the Animal Body. 1912, 107. Iondon: Iongmans, Green $\& \mathrm{CO}$. 
(9) BRIFGER, I.: 'Ueber die flüchtigen Bestandtheile der menschlichen Excremente.' (aus a. Lab. von Prof. Nencki in Berm). Ber. a. deutsch. chem. Gesellsch. 1877, $\mathrm{x}, 1027-1032$.

(10) NiNCKI, M.: 'Vortheilhafte Darstellung des Skatols.' Centralblatt f. d. med. Wissenschaft. No.47.

(11) GAMGEE, A.: A Text-Book of the Physiological Chemistry of the Animal Body. 1893, ii, 425. Iondon: Macmillan \& Co.

(12) HERTER, C.X.: The Occurrence of Skatol in the Human Intestine.' Jour. of Biol. Chem. 1908, iv, 101 .

(13) BAEYER, A.: Ann Chem. u. Pharm. cxi, 295. and A. Emmerling and C. Engler, Ber. d. deutsch. chem. Gesellsch. 1, 17, and 1i1, 885 .

(14) NWWKI, M.: 'Üeber ale Harnfarbstoffe aus der Indigogrouppe und über die Pankreasverdauung.' Ber. d. deutsch. chem. Gesellsch. 1875, vili, 336 . 'Ueber das Indol.' Ibia. 1875, vi11, 722.

(15) KUHWE, W.: Ber. d. deutsch. chem. Gesellsch. 1875, viil, 206 .

(16) SAJKOWSKI, E.: Zur Kenntniss du Eiweissfaulniss, 1: Ueber die Bildung des Indols and Skatols, nach gemeinschaftlich mit $H$. Salkowski in Munster angestellten Versuchen. 'Ze1t. $f$. physiol. Chem.' 1883-4, vii1, 417-466. 
(17) VIRCHOW, R.: 'Zur Chemie des Pancreas.' Virchow's Archiv. 1854, vii, 580 .

(18) FRERICH, F.J.: Frerich'a Deutsche Klinik. 1855, No.31, KIinik der Leberkrankheiten.' 1858.

(19) KÜHNE, W.: 'Ueber die Verdauung der Eiweisstoffe durch den Pankreassaft.' Virchow's Archiv. 1867, $\operatorname{xxoxix}, 130$.

(20) RADZIEJEWSKY, S.: 'Das Vorkommen von Ieucin und Tyros in in normalen Körper'. (aus dem chemischen Laboratorium des pathologischen Instituts zu Berlin). Virchow's Archiv. 1886, xyaxvi, $1-14$.

(2I) NEWCKI, Y.: IUntersuchungen uber die Zersetzung des Elweisses durch anaerobe Spaltpilze.' Monatshefte f. Chem. 1889, x, 306 and 908.

(22) Batmann, E.: Zeit. f. physiol Chem. 1880, 17, 305.

(23) BAUMANN, E.: Berichte d. deutsch, chem. Gesellsch. xil, 1453. Drechsel, Chemie der Absenderungen una der Gewebe.' Hermann's handbuch. V.I.

(24) TRAETTA HOSCA, F.: 'I fermentazione della tirosina.' Gazz. Chim. Ital., 1910, xI, 86 .

(25) SAJKOHSKI, E. \& H.: Ber. d. deutsch. chem. Gesellsch. xi1, 650 . 
(26) BAUIAINN, E. \& L. BRIEGER: 'Uober die Entstehung von Kresolen bei der Fäulniss.' Zeit. f. physiol Chem. 1879, iii, 149.

(27) WEYI, T.: 'Spaltung von Tyrosin durch Fäulniss.' Zeit. f. physiol Chem. 1879, iii, 312.

(28) RUNGE, : Encyclopedia Britannica. 9th ed. 1898, $\nabla$, 85. Edinburgh: Adam \& Charles Black.

(29) BAUMANN, E.: 'Zur Kenntniss der aromatischen Substanzen des Thierkörpers.' Zeit. 1 . physiol Chem. $1877-8,1,60-69$.

(30) BRIEGER, I.: Veber die fluchtigen Bestandtheile der menschlichen Excremente' (aus d. Laborat. von Prof. Nenck1), Ber. d. deutsch chem. Gesellsch. $1877, x, 1027$ et seq. 


\section{SECTION I.}

\section{OBSERVATIONS UPON PUTREFACTION.}

\section{REVIEW OF SAIKOWSKI'S EXPERIMENTS UPON THE PRODUCTION OF INDOI.}

Salkowsk1's work is of special interest because he focussed his attention upon one particular product of putrefaction namely, indol, as regards its properties and the conditions under which it appeared. Incidentally, a survey of his experiments provides a more detalled conception of putrefaction as an isolated process of vital destruction of organic matter, than is to be found in many other records of the subject. Furthermore, since Salkowski's experimental technique has been adopted in the experiments of this thesis, the following detallo of his work warrant consideration.

Prior to the commencement of Salkowski's work in this connection, an indigo-yielding substance had been found by Schunk (I) to exist in the leaves of certain plants of the leguminous genus, Indigofera. The discovery of this substance in the form of a colourless gluooside called indican, provoked considerable interest, in view of 1 ts striking colour reactions, its relationship to indigo, and its apparent identity with the indigo-yielding substance which had been previously found in the urine of man and animals. Hoppe-Seyler (2) in 1863, examined a series of 100 samples of human urine and agreed with Schunk's assumption that the indigo obtained from urine was identical with that found in plants. In 1877 , Jaffé (3) observed an excessive output of indican in the urine in several cases of lleus and peritonitis thas raising the question of the association betreen indican and the indol arising from decomposition of proteins in the/ 
the intestine. A year earlier salkowsk1 (4) had observed both indican and phenol in the urine of a few cases of ileus. In one of his cases, Salkowski had also detected a large amount of benzoic acla. In the light of Jaffe's subsequent publication of his findings on indicanuria, Salkowski, referring to his previous observations, thought it possible that benzoic acid might be a product of intestinal putrefaction. He set out, therefore, to investigate systematically a series of cases of lleus but found no excess of benzolc acid in any of them. It transpired. later that the patient, from whom the original specimen of urine containing benzoic acid had been obtained, had been receiving oral administration of benzoic acid. Thereafter, he eventually developed his experiments into an investigation of putrefaction products in general. It was thus from the clinical field that salkowski's researches upon the chemistry of putrefaction were instigated.

Salkowski (5) dealt specially with the quantitative aspect of putrefaction with the object of determining more particularly the mode of formation of indol and skatol. Like many other investigators he sought a conception of vital activity from deductions based upon the results of that activity, He selected his media of know weight and constitution, subjected them to putrefaction for a given time and then by estimation of changes which had taken place, he was able to arrive at a conception of the extent and nature of the process of putrefaction, under given circumstances. As one of his media, he choose horse-flesh in view of its ready procurability in large quantities, its great putrefactire capacity and the fact that it represented the form in which a large part of the albumen of the homan food was taken. Blood fibrin, flesh and masele fibrin, serum albumen and pancreas-peptone were also selected as representative ind1ridual/ 
individual substances which, in the ordinary course of nature, outside and inside the animal body, were exposed to putrefaction.

Having decided upon his various media, Salkowskl was next faced with the question of whether he would subject these media to auto-infection from the air or to inoculation with special organisms. He decided against the latter course, since the necessary sterilisation of the medium would have caused considerable alteration in the physical properties, which were essential to the rapidity and the start of putrefaction. The techical difficulties attendant upon sterilisation of such large quantities of meat represented another factor in the decision. He considered also, that the decomposition of albumen produced by auto-infection from the air coincided more with that which took place in the intestine under physiological conditions. While admitting the need for the investigation of the part played by special organisms in putrefaction, Salkowski thought that he was justified in dispensing with special sterilisation of his media since his objective was to examine the results of activity in gezeral, of the organisms usually present in the air or on the surface of objeots. In the experiments on horse-flesh he employed $2 \mathrm{kllogrammes}$ of his medium to which 2 litres of river-water at $40-42^{\circ} \mathrm{C}$ and $200 \mathrm{cos}$. of saturated sodiumasolution were added. This mixture, he then inooulated with a few cos. of a putrefactive mixture which had been proviously propared by mixing a small quantity of chopped meat with water and sodium carbonate and allowing to incubate at $40^{\circ} \mathrm{C}$. For 12 hours. The flask containing the medium thus inoculated, was then loosely closed with a cork and placed in the incubator at $40^{\circ} \mathrm{C}$ for $4-6$ days. At the end of this time, the contents of the flask were subjected to distillation. The distillate and the residue were then 
examined quantitatively. The other media were treated in the same way. In the case of the blood-fibrin experiments, however, acid potassium phosphate and magnesium sulphate were added to the medium in proportionate amounts. From these experiments, Salkowski found that, on an average, blood-fibrin yielded about three times as much indol as the albumen substance of horse-flesh while the average amount of albumen decomposed in each case was 80-90\% of the original albumen contents. A summary of his results are given below. The putrefaction of 2000 grms. of blood-fibrin for 4 days at $40^{\circ} \mathrm{C}$ jlelded $3.093 \mathrm{grms}$. of indol $(0.72 \%$ of the albumen decomposed) and resulted in the decomposition of $432.2 \mathrm{grms}$. of albumen ( 90 of the original albumen content). Additional figures are tabulated as follows:-

\begin{tabular}{c|c|c|c|c|l}
\hline Medium & $\begin{array}{c}\text { Quantity } \\
\text { Grms }\end{array}$ & $\begin{array}{c}\text { Duration } \\
\text { of } \\
\text { putrefaction }\end{array}$ & $\begin{array}{c}\text { Indol } \\
\text { Grms. }\end{array}$ & $\begin{array}{l}\text { Albumen } \\
\text { decomposed } \\
\text { Grms. }\end{array}$ & $\begin{array}{c}\text { Percen - } \\
\text { toge }\end{array}$ \\
\hline Blood fibrin & 1714 & 13 & 4.0594 & 386. & 91.8 \\
\hline " & 2000 & 26 & 3.892 & 397.7 & 98. \\
\hline Horse flesh & $n$ & 4 & 0.702 & 366.4 & 91.5 \\
\hline " & $n$ & 8 & 0.900 & 370.9 & 92.7 \\
\hline $\begin{array}{c}\text { Muscle fibrin } \\
\text { Rabbit flesh } \\
\text { powder }\end{array}$ & 75 & 10 & 0.208 & 61.7 & 92.3 \\
\hline $\begin{array}{c}\text { Horse flesh } \\
\text { powder }\end{array}$ & 150 & 30 & 0.350 & 125.85 & 94.6 \\
\hline $\begin{array}{c}\text { Serum Llbumen } \\
\text { " }\end{array}$ & 150 & 37 & 0.433 & 104.4 & 87. \\
\hline $\begin{array}{c}\text { Pancreas Peptone } \\
\text { " }\end{array}$ & 180.5 & 7 & 1.050 & 173. & 95.8 \\
\hline
\end{tabular}


From the above table it is seen that indol was found to be a constant product of albumen putrefaction. Its production was seen to vary with the nature of the medium and with the duration of incubation. For example 2000 grms. of blood fibrin incubated for 4 days at $40^{\circ} \mathrm{C}$ yielded $3.093 \mathrm{grms}$. of indol, while the same amount of horse-flesh under the same conditions ylelded only 0.702 grms. of indol. Furthermore, $2000 \mathrm{grms}$. of blood-fibrin incubated for 26 days at $40^{\circ} \mathrm{C}$. yielded $3.892 \mathrm{grms}$. of indol while $2000 \mathrm{grms}$. of horse-flesh under the same conditions, yielded $1.112 \mathrm{grms}$. of indol.

In these experiments, Salkowski, made no attempt to isolate the particular organisms concermed in the putrefaction of his various media. Auto-infection from the air was the common factor in each case. Under these circumstances, having observed the variability of indol production in relationship to the nature of the medium and the duration of incubation, Salkowski also directed his attention to the earliest time of occurrence of indol in the course of putrefaction. In the case of blood-fibrin and horse-flesh media, he was able to recognise indol after 2 days incubation at $40^{\circ} \mathrm{C}$. He found that indol was not present in putrefactive mixtures as soon as they ovolved the characteristic odour. of sulphuretted hydrogen but that it occurred at a later staga This point is of interest in view of the frequency of the odour of sulphuretted hydrogen in putrefaction since it would suggest that when this odour is first detected the process of decomposition has not necessarily reachod the stage of indol production. On the basis of his observation concerming the earliest time of occurrence of indol, Salkowski suspected that this substance was not formed directly from the protein molecule but through the dissociation of an intermediate substance/ 
substance. He observed also that the quantity of indol increased at first with the progress of putrefaction up to 13 days, after which time diminution from evaporation tended to take place. The stability of indol, however, was indicated by the fact that its presence was usually recognisable for many months in any of the putrefactive media, provided that volatilization and oxidation were prevented. Salkowski stated that it had been recognised in an ascitic fluid 10 years old.

Pertinacity was another property of indol demonstrated by salkowski. It tended to adhere to substances which eventually became orange-coloured by its presence.

He found, also, that indol had a distinct antiseptic action. The presence of $0.75 \mathrm{grms}$. of indol in a mixture of $7.5 \mathrm{grms}$. of flesh powder, $750 \mathrm{ccs}$. of water and $12 \mathrm{ccs}$. of saturated sodium carbonate solution was sufficient to inhibit putrefaction.

Salkowski's observations from these experiments indicated that indol was a constant product of putrefaction and that it was a stable although readily volatilizable substance, possessed of pertinacious properties and an antiseptic action. The features of indol thus demonstrated were certainly suggestive of the fact that this substance was essentially an end-product associated with the completion of a vital process, and that, under conditions of auto-infection from the air, different amounts were yielded by different media. 


\section{BIBLIOGRAPHY. (SECTION I.C.)}

(1) SCHUNK, : Liebig u. Kopp. Jahresbericht. 1857.

(2) HOPPE-SEYLER, F.: Archiv, fur Path. Anatomie Virchow. 1863, xxvi1, 388.

(3) JAFTE, M.:" D1e Ausscheidung des Indikens water Fhys-path. Verhaltnissen. 1877. Ar.A. 70, 78 .

(4) SAIKOWSKI, E.: Zur. Kenntiss der Eiweissfaulniss 1: Ueber Bildung des Indols und Skatols nach gemeinschaftlich mit H. Salkowski in Munster angestellten Versuchen.' Zeit. f. physiol Chem. 1884, vili, 417 . 
D. EXPERIMENTS.

The experiments described in this section contain certain observations which I have made upon the putrefaction of meat by auto-infection from the air. The experiments were carried out in the Physiological Chemistry Laboratory of the Department of Physiology at Glasgow University over a period extending from 1922 to 1930.

$\Delta s$ in Salkowski's experiments, no attempt was made to inoculate the media with specially selected organisms since it was desired to observe any constancy which might exist in the changes associated with the ordinary putrefaction of meat. In support of Salkowski's views it was considered, also, that such experimental conditions were more analogous to those within the intestine. Furthermore, since organisms endowed with proteolytic powers are known to be practically omipresent throaghout the atmosphere, potential auto-infection from the air may be taken to represent an almost universal condition under which all biological processes take place.

\section{EXPERIUIAT I.}

CHANGES OCCURRTIG II $\triangle$ MIXTURE OF KACERATED OX-FLESH AND Iristh.

\section{Technique.}

The experimental technique adopted, was that of Salkowsk1. (1)

100 grms. of Iresh macerated ox-flesh, killed two days previously, were placed in a glass flask of one litre capacity. 500 ec8. of sterile water and $20 \mathrm{cos}$. of saturated/ 
saturated sodium carbonate solution were then added and the flask was well shaken in order to promote thorough mixing of the contents. The mixture was then inoculated with 5 ces. of a putrefying meat mixture. This inoculation mixture was prepared by placing $10 \mathrm{grms}$. of fresh uscerated ox-flesh, $100 \mathrm{ccs}$. of water and $1.2 \mathrm{ccs}$. of saturated sodium carbonate solution in a flask which was loosely closed with cotton wool and then allowed to incubate at $40^{\circ} \mathrm{C}$ for 24 hours. At the end of this time, the onset of putrefaction rendered it sultable for inoculating purposes. The reaction of the original meat mixture thus inioculated, was then taken in terms of an approximate pil. value by removing a few ccs. into a test tube and adding 2 drops of an appropriate indicator.* In the ereshly prepared state, the reaction of the mixture was found to be pH. 10 approximately. The flask was then closed by a rabber cork, provided with two openings. Through one of those openings a glass tube was fixed connecting the flask with a deodorant mixture of potassium permanganate. Through the other opening, a piece of thin glass tabing was passed perpladoularly and loosely closed with cotton wool at its upper outlet. (Fig. I.)/

The B.D.H. Universal indicator was used throughout these experiments. This indicator, which gives an approximate $\mathrm{pH}$. range from $\mathrm{pH}$. 4. to $\mathrm{pH}$. II, contains the following indicators:-

Methyl Red.

Naphtholphthalein.

Phenolphthalein.

Brom. Thymal blue.

Cresolphthalein. 


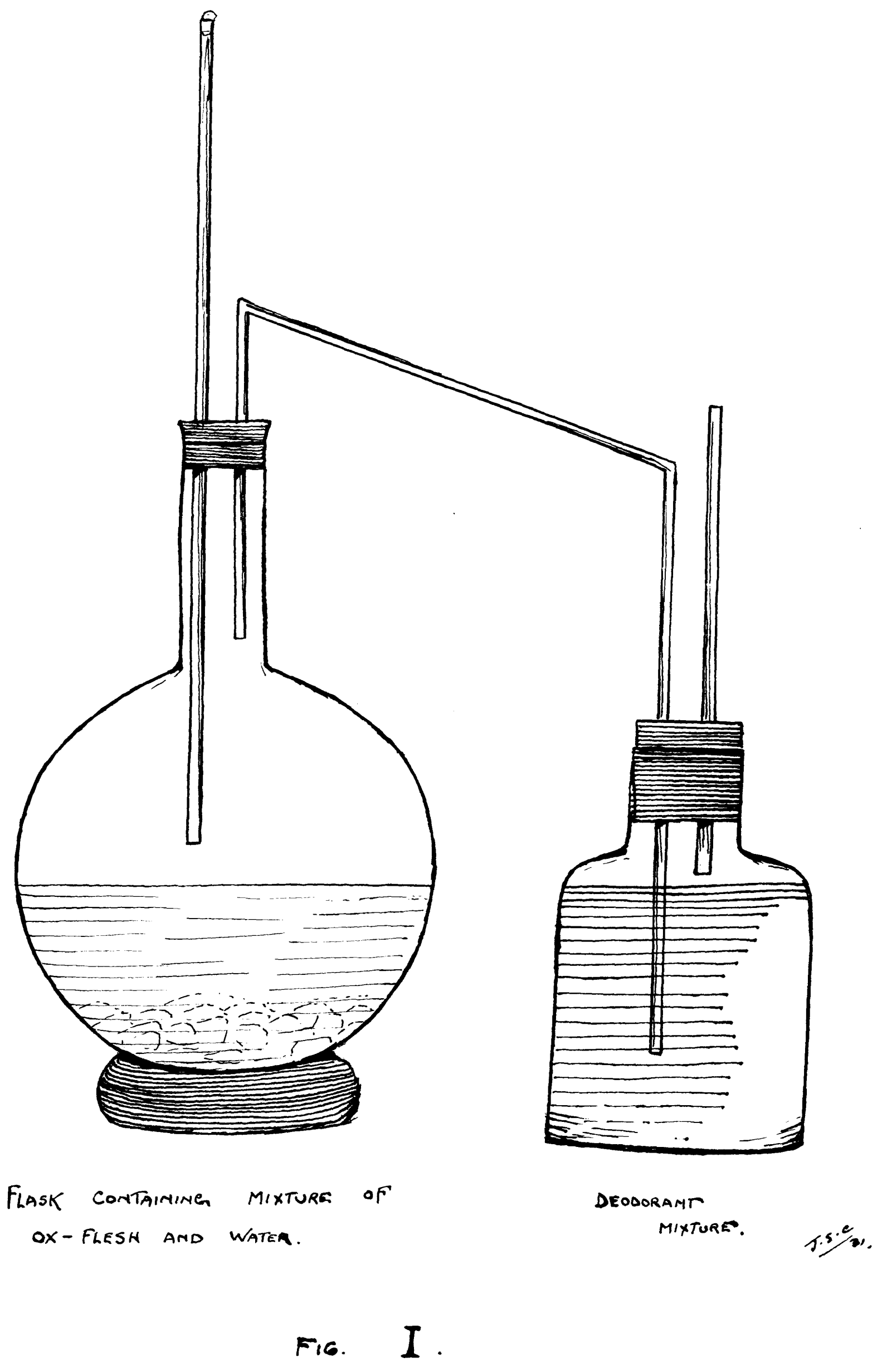


The flask was then placed in the incubator for 4 days at $40^{\circ} \mathrm{C}$. Throughout this period of incubation, daily observations of colour, odour, reaction and organismal activity were made. The changes noted, are recorded in the following table:-

TABIE 1 :

\begin{tabular}{|c|c|c|c|c|}
\hline TIME & COLOUR & ODOUR & $\begin{array}{c}\text { REACTION } \\
\text { Approx. }\end{array}$ & ORGAN ISMS \\
\hline $\begin{array}{l}\text { Before } \\
\text { Incubation }\end{array}$ & $\begin{array}{l}\text { Red and } \\
\text { clear }\end{array}$ & $\begin{array}{c}\text { Fresh } \\
\text { arightly salthe }\end{array}$ & 10. & Absent \\
\hline $\begin{array}{l}\text { After } \\
24 \text { Hours }\end{array}$ & $\begin{array}{l}\text { Red becoming } \\
\text { turbid. } \\
\text { Gas bubbles } \\
\text { on surface }\end{array}$ & $\begin{array}{c}\text { Putrefactive. } \\
\mathrm{H}_{2} \mathrm{~S} \\
\text { detectable. }\end{array}$ & 9. & $\begin{array}{l}\text { Several } \\
\text { motile } \\
\text { forms. }\end{array}$ \\
\hline $\begin{array}{l}\text { After } \\
48 \text { Hours }\end{array}$ & $\begin{array}{l}\text { Brownish red } \\
\text { and turbid. } \\
\text { Gas bubbles }\end{array}$ & $\begin{array}{c}\text { Putrefactive, } \\
\text { more marked }\end{array}$ & 8.5 & $\begin{array}{l}\text { Motile } \\
\text { forms more } \\
\text { numerous }\end{array}$ \\
\hline $\begin{array}{l}\text { After } \\
72 \text { Hours } \\
(3 \text { days })\end{array}$ & $\begin{array}{l}\text { Brown and } \\
\text { turbid. } \\
\text { Gas bubbles }\end{array}$ & $\mathrm{H}_{2} \mathrm{~S}$ strong & 8.5 & $\begin{array}{l}\text { Motile } \\
\text { forms very } \\
\text { numerous }\end{array}$ \\
\hline $\begin{array}{l}\text { After } \\
96 \text { Hours } \\
\text { (4 days) }\end{array}$ & $\begin{array}{l}\text { Dark brown } \\
\text { and turbid } \\
\text { Gas bubbles } \\
\text { diminishing }\end{array}$ & $\begin{array}{l}\mathrm{H}_{2} \mathrm{~S} \text { slightiy } \\
\text { less marked }\end{array}$ & 8. & $\begin{array}{l}\text { Motile } \\
\text { organisms } \\
\text { in densely } \\
\text { crowded } \\
\text { flelds. }\end{array}$ \\
\hline
\end{tabular}

\section{Descriptive Comments on Table 1.}

Colour.

The original colour of the mixture, which, before Inoubation, was red, was changed through various shades of brown, to a final dark brown colour on the fourth day. The first change in colour became noticeable after 24 hours' incubation and coincided with the appearance of turbidity in the supernatant fluid which had been originally clear and also with the formation of gas bubbles, and the detection/ 
Colour (Continued).

detection of a putrefactive odour. Coincident with these changes also, an alteration in reaction and the development of organismal life were observed.

Odour.

A definitely repulsive odour, in which sulphuretted hydrogen predominated, was first detected after 24 hours' incubation. This odour tended to become intensified during the interral between the second and third days of incubation, after which time it became less marked.

\section{Reaction.}

The original reaction of the mixture before incubation and after 1t had been rendered alkaline by the addition of saturated sodium carbonate solution was approximately, pH.10. The first alteration after 24 hours' incubation took place in the direction of acidity. The reaction although diminished in its degree of alkalinity, was alkaline at approximately $\mathrm{pH} .8$ on the fourth day of incubation. As previously mentioned, the first alteration in reaction coincided with the first changes in the appearance of the mixtare, with the development of the putrefactive odour and with the first signs of organismal life.

\section{Organisms.}

Lt the end of the first day of incubation, a few drops of the supermatant fluid of the putrefactive mixture were examined microscopically, on an open slide, under a high power. Motile forms were thus readily detectablo. In this instance, visible motility was taken as an index of organismal 11fe. Motile forms which were first detected after 24 hours' incubation became more numerous on the second/ 
Organisms (Continued).

second and third days. On the fourth day of incubation, motile organisms were seen to be present in densely crowded fields.

Physical, chemical and bacteriological changes were thus seen to be initiated in a mixture of macerated meat and water, auto-infected from the air, after 24 hours' incubation at $40^{\circ} \mathrm{C}$. The salient features of these changes were as follows:-

Change in colour from red to brown.

Change in translucency from clear to turbid.

Gas formation with bubbles and putrefactive odour.

Change in reaction. Reduction in alkalinity. The appearance of organismal motility.

These characteristic changes were apparently synchronous in their onset.

Technique continued:-

After incubation, the putrefactive mixture ras subjected to steam distillation and subsequent analysis according to Salkowski's technique. For descriptire purposes, the elask containing the meat mixture is now designated $A$.

$500 \mathrm{ccs}$. of water were placed in a separate flask of I IItre capacity, designated B., which was used as a steamgenerator. This flask was provided with a piece of glass tubing which extended donward to the level of the water and upwards into the air to a height of $2 \frac{1}{2}$ times that of the llask, to allow for effective steam exhaust. Flasks A. and B. were then placed upon sand-baths on retort-stands. A. Was connected on one side with B. by a length of glass tubing and on its other side, it was connected with a Iiebigh condenser through which cold water was allowed to circulate (F1g. II.)./ 


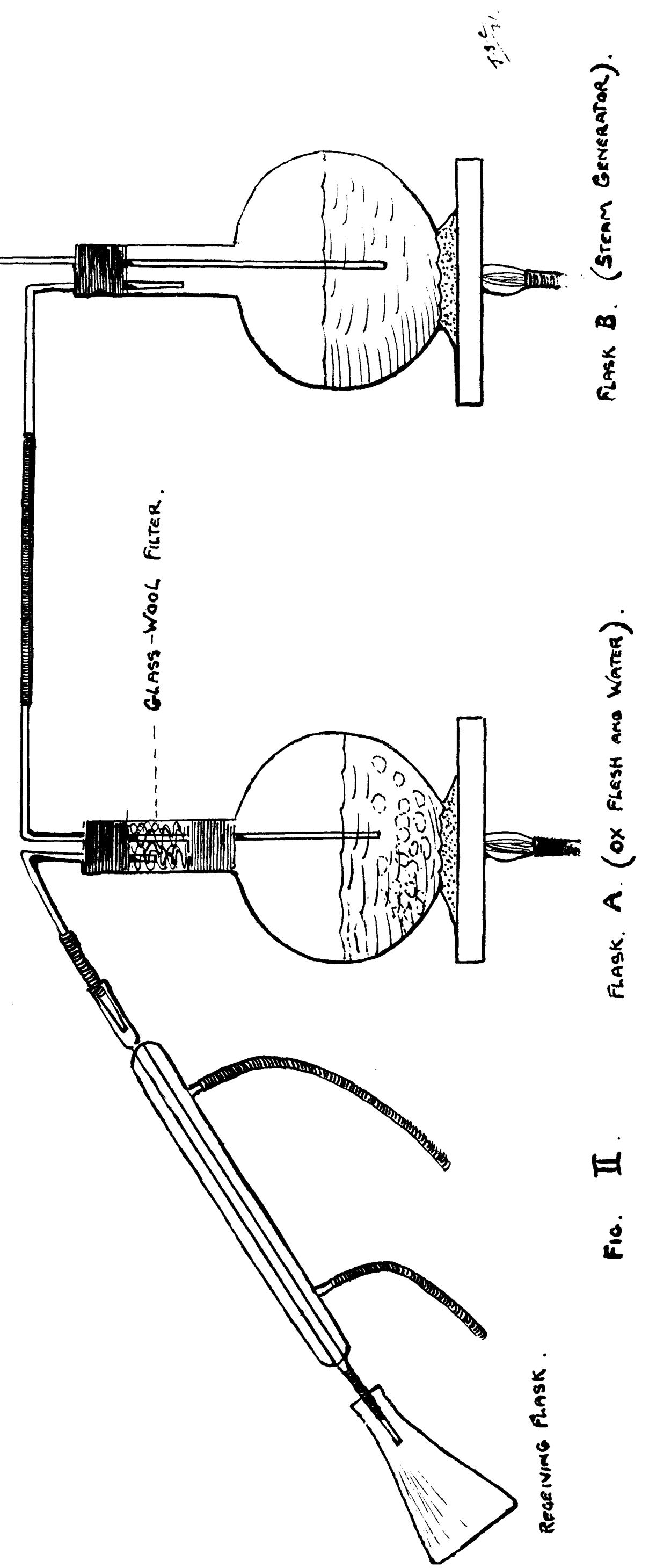


Technique continued:-

A receiving flask was placed at the outlet of the condenser. In order to prevent frothing, flask A. was provided with a glass-wool filter. This consisted of an additional rubber cork, inserted towards the base of the neck of the flask. This mabber cork had two openings. Through one of these, passed the steam inlet tube from B., the other opening was covered at its upper end with glass wool which was packed into the neck of the llask in the interval between the two corks. Several glass beads were placed in each flask to prevent undue bumping on bolling. Before commencing distillation, all the rubber and glass connections between the flasks were examined and adjusted to ingure an uninterrupted passage of steam from B. to A. and of distillate from A. through the condenser. A bunsen burmer was then placed under each flask and heating was commenced synchronously. B. was heated more rapidy than $A$. and the bunsen flame was kept at a level sufficient to maintain vigorous boiling. A. was heated more gradually and maintained at an optimum heat, sufficient to allow of the passage of steam from B. After thus heating the flasks for li hours, the first drops of distillate entered the receiver. The first $50 \mathrm{ccs}$. of distillate recovered were removed from the receiver for examination. The recelver was then replaced for collection of subsequent distillate. The following physical and chemical characters of the distillate were noted:Colour. The fluid was colourless, slightly turbid and apparently somewhat oily in consistence.

odour. The odour was penetrating, almost like that of cooked meat, slightly ammoniacal but not repulsive.

Reaction. The reaction was p. 1l. approximately. Separate portions of the distillate were then tested qualitatirely for the following substances:- 
Technique continued:-

Qualitative Tests.

Sulphuretted Hydrogen.

A few drops of freshly prepared saturated sodium nitroprusside solution were added to $1 \mathrm{cc}$. of the distillate. A deep reddish violet colour was obtained, indicative of the presence of a sulphur compound. A few arops of lead acetate solution were added to 2 ccs. of distillate. A black precipitate was immeilately obtained indicative of the presence of sulphuretted hydrogen.

\section{Ammonia.}

A few arops of Nessler's reagent* were added to $2 \mathrm{ccs}$. of the distillate. The characteristic precipitate indicative of the presence of ammonia was obtained.

Indol.

Legal's Test. A few drops of freshly prepared saturated sodium nitro-prusside solution were added to 2 ces. of distillate. A reddish violet colour was obtained as previously described in the first test for sulphuretted hydrogen. The further addition of a few drops of saturated caustic soda solution caused the development of a dark brom colour. On acidifying with three drops of glacial acetic acid, a deep azure blue colour was obtained, indicative of indol.

The/

$*$ Nessler's Reagent. Composition:

IO; sodium hydroxide. $700 \mathrm{c} . \mathrm{c}$. Double Iodide solution. I50 c.c. Distilled Vater. I5O c.c. 
Indol.

(Legal's Test continued).

The presence of indol was confirmed by the following aditional tests:-

Erlich's Test. The composition of the reagent employed is, as follows:-

P. dimethyl amido-benzaldehyde Gi 4 .
Alcohol absolute.
cc. 380
Acid hydrochlor conc.
cc. 80

A few drops of this reagent were added to 1 cc. of the distillate. A deep red colour developed, indicative of Indol.

The Vanilin Test. Three drops of 5\% solution of vanillin in $95 \%$ alcohol were added to $2 \mathrm{ccs}$. of distillate which was then acidified with $4 \mathrm{ccs}$. of concentrated hydrochloric acid. A positive indol reaction was obtained in the form of a brilliant orange colour.

The Nitroso-Indol Reaction. Five drops of a $1 \%$ solution of sodium nitrite were added to $5 \mathrm{ccs}$. of the distillate. On the further addition of 2 drops of strong sulphuric acid, an orange red precipitate of nitrite of nitroso-indol was formed.

\section{Skatol.}

Vanilin Test. The same procedare was adopted as in the case of the corresponding test for indol, previously described. The orange coloured solution obtained after the addition of $4 \mathrm{cos}$. of concentrated hydrochloric acid was boiled, then cooled. $3 \mathrm{ccs}$. of chloroform were then added and the mixture was well shaken. 1 violet colouration developed in the chloroform layer, indicative of skatol.

\section{Phenol'}


Phenol.

Millon's Test. I few drops of Millon's reagent* were added to $3 \mathrm{ccs}$. of the distillate. A whitish precipitate was formed, which on boiling assumed a red colour, as a general reaction of all aromatic bodies.

The Bromine Test. A few ccs. of bromine water were added to $2 \mathrm{ccs}$. of the distillate. The characteristic yellow precipitate of tribromophenol was obtained.

Technique continued:-

By testing the distillate qualitatively throughout the period of distillation a negative reaction for indol was not obtained until $300 \mathrm{ccs}$. of distillate had passed over. At this point, the reaction for phenol was still positive and it did not become negative until 400 ccs. hal passed over when distillation was stopped.

With regard to the variation in the reactions of the other substances in the distillate, the reaction for $\mathrm{H}_{2} \mathrm{~s}$ disappeared early, after about $30 \mathrm{cos}$. of distillate had been recovered. The reaction for ammonia, al though persisting throughout the greater part of the period of distillation tended to become much less marked towards the end as the reaction of the distillate became less alkaline. The last arops of distillate were 7 9. approximately. Further/

*

Millon's reagent is a solution of mercurous nitrate in nitric acid. 
Further analysis of the distillate was carried out as follows:-

$400 \mathrm{ccs}$. of distillate were removed from the receiver and were divided into four portions, each of $100 \mathrm{ccs}$. The first portion of 100 ccs. was acidified with a few drops of concentrated hydrochloric acid and was then transferred to a separating-funnel and extracted with ether. This procedure was repeated with each of the three remaining portions of the distillate, fresh ether being used in each case. All the pther extracts were then collected in one vessel. The acid aqueous solutions were also collected in a separate vessel and allowed to evaporate spontaneously. The following table, according to Salkowski, represents the various steps in analysis:-

Distillate acidified with HCI. and extracted with ether.

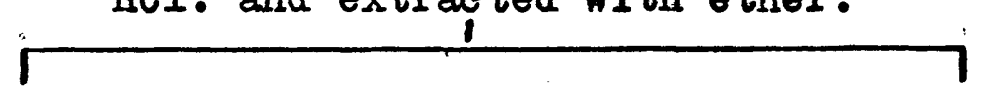

Ether Sol. A. Shaken with NAOH. Aque ous Fluid B. evaporated
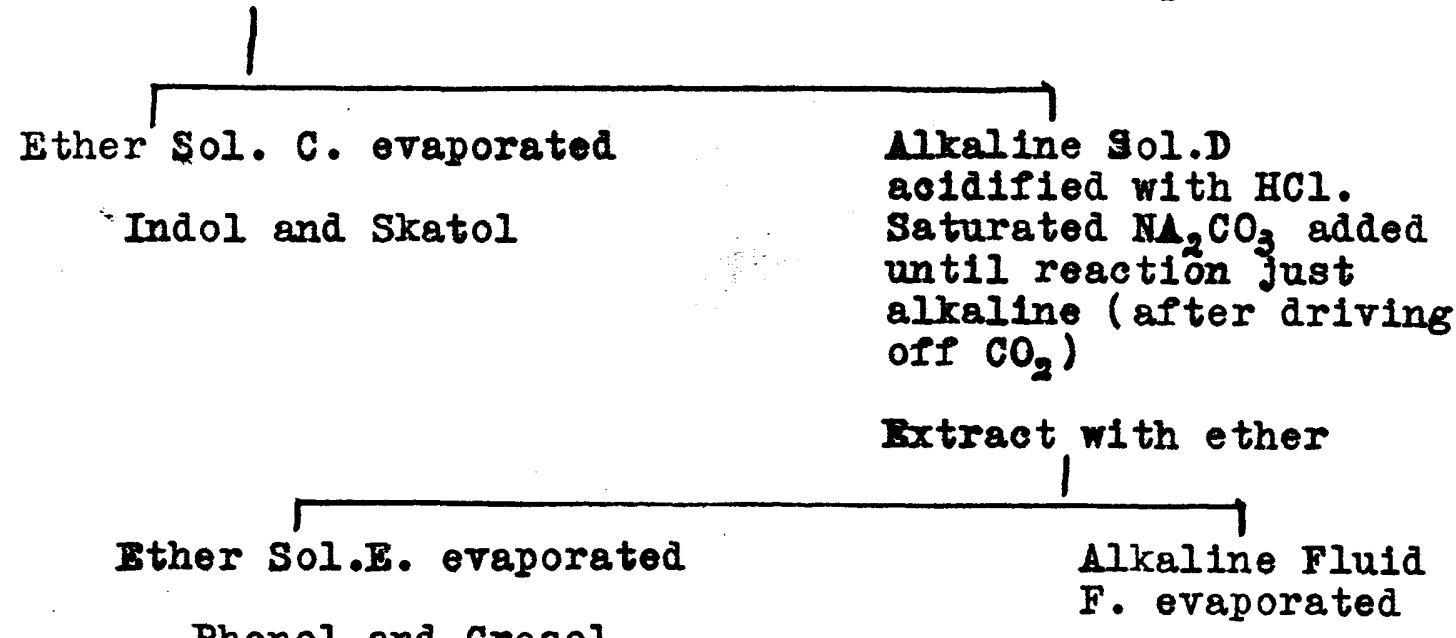

Phenol and Cresol.

Technique continued:-

Ether Solutions A. and C.

The total ethereal extract designated $A$. was then thoroughly/ 
thoroughly shaken with an equal portion of a solution contalning equal parts of saturated caustic soda and warm water. The alkaline aqueous fluid D. resulting therefrom was witharawn into a porcelain dish. The ether solution C. was allowed to evaporate spontaneously in a large watch glass at room temperature. After 24 hours' evaporation of ethereal extract $C$. a layer a plate-like crystals remained, partly adherent to the sides of the watch-glass and partly floating upon the surface of a somewhat oily and amorphous mass. On further evaporation these crystals became aggregated in small clumps or coln-like piles,(Fig.III Microphotograph).

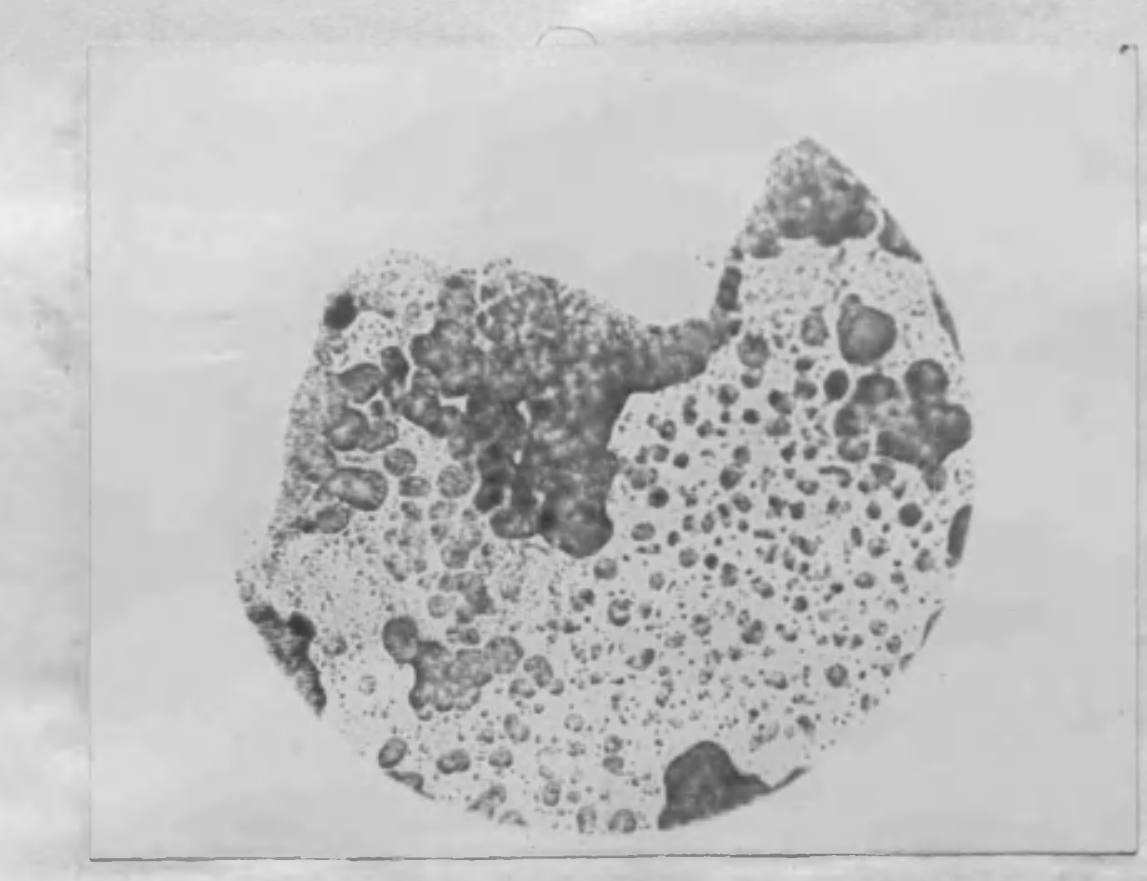

FIG. III MICROPHOTOGRAPH. SHOWIME CLUMPS OF INDOL CRYSTALS.

Each crystaline plate was discrete and could be easily picked up with a pair of fine dissecting forceps. A few of the crystals were transferred to a slide and examined microscoplcally under low power. In shape they were chiefly polygonal with rounded comers and numerous sharp pronontories. The interior of each crystal presented an/ 


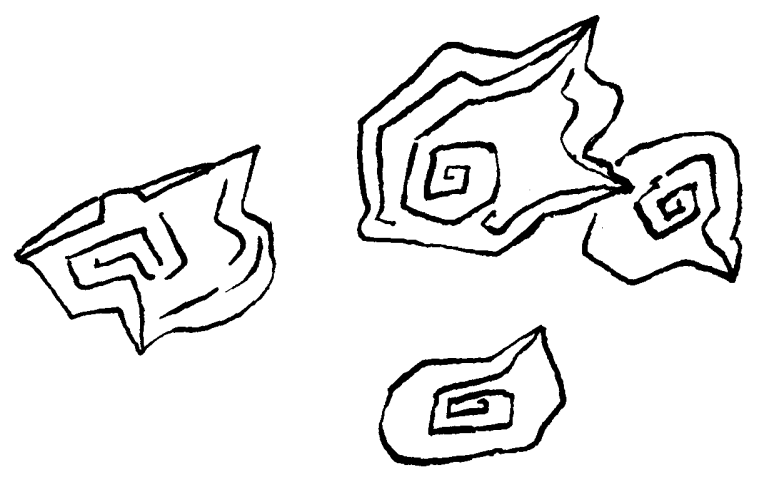

FIG IV SKETCH OF INDOL CRYSTALS
(UNDER LOW POWER. MAGNIFIED) 
an appearance of concentric lamination (Fig. IV.). The crystals had a penetrating and slightly faceal odour. They were readily soluble in hot water but moreso in ether. On heating the slide over a bunsen flame the crystals meltea quickly forming clear oily droplets with a characterstic odour and which, on cooling, assumed their former crystalline shape. A solution of the crystals gave positive reactions to all the tests for indol and skatol, indicating that they were composed of an admixture of these two substances. No attempt was made to separate skatol and indol.

According to Salkowski, the mixture of indol and skatol thus obtained is impure, usually containing traces of phenol and cresol. He recommends further distillation for purification purposes. The crystals, together with the oily amorphous residue resulting from the evaporation of ether solution C., were redissolved in hot water and extracted with ether. This solution was then distilled in a small direct distillation flask of 50 ccs. capacity. On gentle heating, the sides of the recelver became coated with a crystalline material which, on examination presented all the characteristic properties of indol and skatol. While this latter process of redistillation may give a purer end-product, the crystalline formation seen so clearly in the original ether extract $C$. was partially lost.

\section{Acid Aqueous Fluid B.}

After evaporation of this fluid, a white crystalline mass, consisting chiefly of ammonium chloride, was found coating the bottom and sides of the porcelain dish. 
Alkaline Solution D. and Ether Solution E.

Alkaline fluid D. was acidified with HCl. Saturated sodium carbonate solution was then added until the reaction was just alkaline, in a cool state, being acid only during effervescence from presence of $\mathrm{CO}_{2}$. The solution thus prepared,was extracted with ether. The acqueous fluid F. was withdrawn to a porcelain dish and allowed to evapordte spontaneously at room temperatare. The ethereal extract F. was transferred to a watch-glass and also allowed to evaporate. After 24 hours of evaporation, the residue of ether extract B. was found to consist of a white crystalline material. Around the periphery of this crystalline mass, and coating the sides of the watch-glass there was a layer 2 of pink coloured semi-oily semi-crystalline substance. This pink coloured olly substance was readily separated from the main mass of white crystals by scraping the sides of the watch-glass with a blade of a pen-knife. 4 portion was transferred to a slide and examined microscopically under low power. No definite crystalline formation could be defined. Small homogeneous pink-coloured grease-like masses were seen. The odour was penetrating and slightly pungent but not faecal. The material was soluble in hot water with disappearance of the pink colour and the formation of slight oily like scum on the surface of the solution. The material was readily soluble in ether. On heating the slide over a bunsen flame, ofly droplets were formed which did not assume any definable crystal formation on cooling, but resumed their original pink coloured grease like appearance. $\Delta$ solution of this substance in water gave a positive reaction to the bromine test/ 
test, forming a characteristic precipitate of tribromophenol.

On the whole, the indentification of phenol and cresol by this extraction method, was not found to be so satisfactory as that for indol and skatol. The positive reaction to the bromine water test was taken as sufficient evidence of the presence of phenol and cresol. Further methods of separation and purification were not pursued.

\section{Alkaline Fluid F.}

After standing for 24 hours this fluid was found to be still of a liquid consistence. Ho further examination of this fluid was made. According to Salkowski's analysis alkaline fluid F. usually reveals sodium salts and fatty acids.

The Distillation Residue.

The residue presented the appearance of a pale brown turbid fluid with much material in suspension. The reaction was . pH. 6 approximately. The residue was removed from the flask and evaporated to dryness in a water-bath. After evaporation, a dark brown grease-1ike material remained. The fat was subsequently extracted with $90 \%$ alcohol and the resultant residue was dried over a steam-bath. After this treatment, the residue was seen to consist of a dark brown semi-crystalline substance with a strong peptone-like odour. On adding hot water to a small pertion of the residue, and titurating, a positive Bluret reaction was obtained.

\section{Summary/}


Summary of Experiment I.

Changes in colour, transparency, odour, and reaction, associated with the development of gas bubbles and organismal life were observed in a mixture of macerated ox-flesh, water and sodium carbonate solution in the course of a period of 4 days'incubation at $40^{\circ} \mathrm{C}$. At the end of this time, indol, skatol, and phenol were recognised in the distillate from this mixture. Some features of the residue were also noted.

These observations were confirmed by subsequent experiments under identical conditions.

\section{Connecting Comments.}

Further to the above observations, the following two aspects of indol production, pertaining to its time of occurrence and its quantity invited consideration:

(1) The time of occurrence of indol in a putrefactive mixture in relationship to the changes described in Bxperiment I. and (2) The amount of indol jielded in a putrefactive mixture over a given period.

\section{EXPER INOETIT II.}

THE TIME OF OCCURREITCE OF INDOL IN A MIXTURE OF MACERATED QX-FIESH ATD VATYR.

Technique.

The experimental technique adopted, was that of Salkowsk1. 
100 grms. of fresh macerated ox-flesh, killed two days previously, were placed in a flask of I litre capacity, to which $800 \mathrm{ccs}$. of tap-water were added. No sodium carbonate solution was employed and no inoculation mixture was added, since it was desired to observe the changes in reaction under natural conditions. The mixture was exposed to auto-infection from the air by closing the flask loosely with a rubber cork. The meat and water mixture was then placed in the incubator at $40^{\circ} \mathrm{C}$. Observations as to colour, odour, reaction and indol production were made daily during the first five days of incubation and subsequently, at intervals, until a period of thirty-seven days had been completed.

Examination for indol was effected by removing small amounts of the mixture (after shaking the contents of the flask to insure the witharawal of representative amounts) at intervals, distilling and testing the distillate for indol. The results obtained are recorded in the following table.

\section{TABIS 2.1}


TABIE 2.

\begin{tabular}{|c|c|c|c|c|}
\hline TIMDE. & COIOUR . & ODOUR. & $\begin{array}{l}\text { RFiACTION } \\
\text { Approx. pH. }\end{array}$ & IND OI. \\
\hline $\begin{array}{l}\text { Before incu- } \\
\text { bation lst. } \\
\text { Bay. }\end{array}$ & $\begin{array}{l}\text { Red and } \\
\text { clear. }\end{array}$ & Fresh & 5.5 & - \\
\hline $\begin{array}{l}\text { 2nd. Day } \\
\text { after } 24 \text { hrs. }\end{array}$ & $\begin{array}{l}\text { Red and } \\
\text { turbid }\end{array}$ & $\begin{array}{c}\text { Putrefactive } \\
\mathrm{H}_{2} \mathrm{~S} .\end{array}$ & 5. & - \\
\hline 3ra. Day & $n$ & $\begin{array}{l}\text { Putrefactive } \\
\mathrm{H}_{2} \mathrm{~S} \text { stronger }\end{array}$ & 5.5 & - \\
\hline 4th. Day & $\begin{array}{c}\text { Redaish } \\
\text { brom }\end{array}$ & $\begin{array}{l}\text { Putrefactive } \\
\mathrm{H}_{\Omega} \mathrm{S} \text { stronger }\end{array}$ & 7. & + \\
\hline 5th. Day & $n$ & $n$ & 7.5 & + \\
\hline$\overline{7 \text { th. Day }}$ & Brown & $\mathrm{H}_{2} \mathrm{~s}$ fainter & 7.5 & + \\
\hline 8th. Day & $\bar{n}$ & $\begin{array}{c}\mathrm{H}_{2} \mathrm{~S} \text { very } \\
\text { faint }\end{array}$ & 8. & + \\
\hline 9th. Dajy & $"$ & $n$ & 8 & + \\
\hline 10th. Day & $"$ & $\begin{array}{c}\text { Repulsive } \\
\mathrm{H}_{2} \mathrm{~S} \text { not dis- } \\
\text { tinct. }\end{array}$ & 8. & + \\
\hline 13th. Day & $"$ & $n$ & 8. & + \\
\hline 20th. Day & $\overline{7}$ & $\bar{n}$ & 8 & + \\
\hline 37th. Day & $\bar{n}$ & $\overline{7}$ & 8 & + \\
\hline
\end{tabular}

\section{Descriptive Comments on Table 2.}

From the above results, it is seen that the earliest indications of change were, alteration in colour due to turbidity, putrefactive odour of sulphuretted hydrogen, and slight increase in acidity on the second day after 24 hours' incubation. These changes were intensified on the third day with the exception of the reaction which diminished in acidity. On the fourth day, all changes were markedly intensfied, the reaction reached alkalinity and/ 
and indol appeared. The appearance of the mixture, at this time, certainly conveyed the impression of a strikingly set change. After the fourth day, the colour proceeded to a darker brown which apparently reached its maximum on the seventh day, after which time there was no appreciable intensification of shade. The odour of sulphuretted hydrogen, which seemed to be at its maximum on the third and fourth days, gradualiy diminished thereafter until it became indistinguishable from the general repulsive odour of putrefaction, which defies accurate description. The reaction, which reached $\mathrm{pH}$. $\%$. on the fourth day, settled at pH. 8 on the eighth day and remained constant at this level, thereafter. The indol reaction was strongly positive from the fourth to the thirty-seventh day. To the observer of the above experiment, therefore, the most striking set of changes took place batween the third and fourth days of incubation at $40^{\circ} \mathrm{C}$.

\section{Summary of Experiment II.}

The time of occurrence of indol in a putrefactive mixtare of macerated meat and water was observed to be the fourth day of incubation at $40^{\circ} \mathrm{C}$. The time of occurrence of indol coincided with definite changes in colour and reaction. The original reaction of the mixture which before incubation was acid (approximate pH. 5.5) reached alkalinity (approximate $\mathrm{pH} .7$ ) on the fourth day.

\section{PXPERIMTITS III. - I.}

\section{THE AMOUNT OF INDOL IN PUTREFACTIVS MIXTURES.}

A series of eight experiments was conducted, with a view to determining the quantitative jield of indol from a knom amount/ 
amount of fresh meat, under given conditions. The first experiment in this series is described in detail. The subsequent seven experiments, which were carried out under the same conditions, are summarised as will be seen from the subsequent text.

For the quantitative estimation of indol, a colorimetric method was employed according to the technique of zoller. In 1919, Zoller (2) described a quantitative method for the estimation of indol in biological media, which was based upon the method previously described by Nonotte and Demanche (3) in 1908. This again was a modification of the original nitroso-indol reaction of Baejer and Nencki. This reaction involves the adaition of indol, followed by the adaltion of a few arops of hydrochloric, sulphuric, or nitric acids, resulting in a red colouration due to the formation of nitroso-indol. Nonotte and Demanche had standardised this reaction by specifying the exact quantities of these reagents which should be employed. Thus 10 drops of 16 sodium nitrite solution were added to $10 \mathrm{cos}$. of the centrifugalised biologiesl medium. This was followed by the addition of 4 drops of concentrated sulphuric aold. The red coldur thas produced, owing to the formation of nitroso-indol, was then compared to a series of standard tubes containing known quantities of indol, whioh had been treated as above. zoller discovered, howerer, that the sensitivity of the reaction could be increased, threefold, by the addition of either isoamyl or iso-butyl alcohol. He found that the alcohol extracted nitroso-indol completely and that the coloured extract rose to the surface, thereby concentrating the full amount of colour within a small area. 
Erlich's reagent, previously described under the qualitative tests for indol, has been employed as a quantitative method by treating $10 \mathrm{ccs}$. of a standard solution of indol with $7 \mathrm{ccs}$. of the reagent and then comparing in the colorimeter, the red colour thus developed with $10 \mathrm{ccs}$. of distillate similarly treated. This method was adapted in several distillation experiments but was discarded in favour of the Zoller method owing to the difficulty experienced in excluding the turblaity of the distillate, which interfered considerably with the final colour reaction.

The Vanilin test,previously described, under the qualitative tests for indol may also be adapted to colorimetry. This method was carried out in the course of several distillation experiments but it was found to be unsatisfactory for the same reason as in the case of the Erlich method.

\section{EXPER IMEAIT III.}

100 grms. of Iresh macerated meat, killed three days previously, were placed in a direct distillation flask of 2 litres capacity containing $500 \mathrm{cos}$. of sterile water and $20 \mathrm{ccs}$. of saturated sodium carbonate. The meat mixture was then inoculated with 5 ocs. of a putrefactive fluid as before. The reaction of the mixture, thus prepared, was pH.10. The flask was then closed with a rubber stopper and placed in the incubator at $40^{\circ} \mathrm{C}$. for eight days. Frequent observations were made as to colour, odour, and reaction throughout the period of incubation as in the following table:- 
TABIE 3.

\begin{tabular}{|c|c|c|c|}
\hline TIME & COIOUR. & ODOUR. & $\begin{array}{l}\text { REACTION } \\
\text { Approx. }\end{array}$ \\
\hline $\begin{array}{c}\text { Before } \\
\text { incubation. }\end{array}$ & Rèd & Fresh & 10 \\
\hline $\begin{array}{c}\text { After } \\
\text { incubation } \\
\text { and. Day. }\end{array}$ & Reddish Brown & $\mathrm{H}_{2} \mathrm{~S}$ & 6.5 \\
\hline 3ra. Day & Brown & $"$ & 7 \\
\hline 5 th. " & " & $\bar{n}$ & 7 \\
\hline 6 th. " & $n$ & $\bar{n}$ & 7.5 \\
\hline 8th. $n$ & n & " & 8. \\
\hline
\end{tabular}

In this experiment, the comparatively sudden diminution in alkalinity on the second day is noteworthy in the light of preceding observations.

After eight days of incubation at $40^{\circ} \mathrm{C}$ the flask was then removed from the incubator and the contents were subjected to distillation.

In this series of experiments, direct distillation was employed instead of steam distillation as in Bxperiment II. Zoller, in his description of the separation of indol from complex media, stated that the method of steam distillation might be abondoned for the more arailable one of direct distillation, provided that recognition was given to the tendency of indol to volatilize more readily from solutions made alkaline above a certain $\mathrm{pH}$. concentration and within the limit of no hydrolytic action. (4) The flask was placed on a retort, glass beads were added to prevent bumping. The tube from the neok of the distillation flask was/ 
was connected by a tunnelled rubber cork with a Iiebig's condenser which again rested, at its outlet, in a receiving flask. Distillation was continued until the distillate no longer gave a positive reaction for indol. In the course of the distillation, an aditional $200 \mathrm{ccs}$. of water were added to the flask and $690 \mathrm{ccs}$. of distillate were eventually recovered.

Colorimetric Method. A standard solution of indol containing $1 \mathrm{mgm}$. of indol per $10 \mathrm{cos}$. of water was freshly prepared in the following manner:100 mgms. of indol were dissolved in $100 \mathrm{ces}$. of hot water. This was used as a stock solution containing $1 \mathrm{mgm}$. of indol per cc. $10 \mathrm{ccs}$. of this stook solution were subsequently diluted up to $100 \mathrm{ccs}$. with water, giving the standard solution of indol containing $1 \mathrm{mgm}$. of indol per $10 \mathrm{cos}$. To $10 \mathrm{ces}$. of this standard solution, 10 drops of $1 \%$ sodium nitrite were added, followed by 4 drops of concentrated sulphuric acld. An orange red colour gradually developed. The coloured solution was then transferred to a separating funnel and extracted with $3 \mathrm{cos}$. of 1so-butyl alcohol. The red colour became concentrated in the uppermost layer. The $10 \mathrm{ccs}$. of stendard solution were extracted again twice, 3 cos. of iso-butyl aloohol being used on each occasion. 9 ccs. of iso-butyl alcohol coloured by its content of nitroso-indol representing $1 \mathrm{mgm}$. indol per $10 \mathrm{ccs}$. were thus finally obtained. The $10 \mathrm{ccs}$. of distillate were treated as above and extracted with three separate portions of 8 cos. of iso-butyl alcohol; $9 \mathrm{ccs}$. of a paler orange red coloured alcoholic solution were thus finally obtained. The two solutions were then set in a Dubos'q colorimeter and their colours were compared. The standard solution was set/ 
set at the mark $15.4 \mathrm{~mm}$. and a match of colour with the distillate was obtained, when the latter stood at $10 \mathrm{~mm}$. The calculation was made as follows:-

Colorimetric Reading $\frac{10}{15.4}=0.64 \mathrm{mgms}$.

The distillate therefore contained $0.64 \mathrm{mgms}$. indol per $10 \mathrm{ccs}$. Since $690 \mathrm{ccs}$. of distillate were actually recovered, the total yield of indol was:-

$0.64 \times 69=44.16 \mathrm{mgms}$.

$=0.04416$ grms.

By this method therefore, $0.04416 \mathrm{grms}$ of indol were recovered from $100 \mathrm{grms}$. of macerated ox-flesh after eight days incubation at $40^{\circ} \mathrm{C}$.

In the above experiment, the distillation residue remaining in the flask was removed to a porcelain basin and placed upon a water-bath. It was then evaporated to dryness and weighed. The fat was not extracted. The results were as follows:-

Weight of basin and dried distillation residue..280.54 grms. Weight of basin.............................

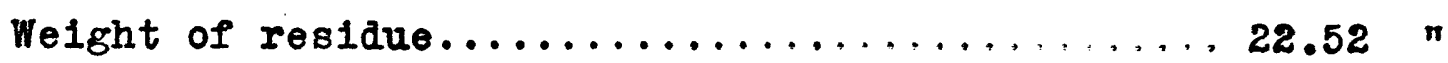

The salient quantitative aspects of the preceding experiment are summarised as follows:-

\section{EXPER IMEATT III.}

Meat

Water

100 grms. ( killed 3 days

$500 \mathrm{ccs}$. previously)

Sodium Carbonate (Saturated)

Inoculated Mixture

$20 \mathrm{ccs}$.

Reaction before incubation

$5 \cos$.

Incubation Period at $40^{\circ} \mathrm{C}$

Reaction after incubation

Technique

Approx. pH. 10.

8 days.

Approx. pH. 8.

Direct Distillation.

\section{Amount /}


Amount of Distillate

Indol yield (Colorimetric)

Distillation Residue
$690 \mathrm{ccs}$.

0.04416 grms. 22.52 grms.

The two subsequent Experiments IV. and V. were carried out at the same time as Experiment III. The three flasks were placed in the incubator synchronously and under the same conditions.

The further experiments of this series are recorded below. The same technique was adopted in each case.

EXPER IMENT IV.

Meat

Water

Sodium Carbonate (Saturated)

Inoculation Mixture

Reaction before incubation

Incubation Period at $40^{\circ} \mathrm{C}$

Reaction after incubation

Technique

Amount of Distillate

Indol yield (Colorimetric)

Distillation Residue
100 grms. ( $\mathrm{k} 11$ led 3 days $500 \mathrm{ccs}$. previousiy)

$20 \mathrm{ccs}$.

$5 \mathrm{cos}$.

Approx. pH. 10

8 days

Approx. pH. 8.5

Direct Distillation

$650 \mathrm{ccs}$.

0.02340 grms.

32.25 grms.

EXPER IMEATT V./ 
EXPER IMENT V.

Meat

Water

100 grms. (killed 3 days

$500 \mathrm{ccs}$.

Sodium Carbonate (Saturate $\bar{i}_{\text {) }} \quad 20 \mathrm{ccs}$.

Inoculation Mixture

$5 \operatorname{ccs}$.

Reaction before incubation

Approx. pH. 10.

Incubation Period at $40^{\circ} \mathrm{C}$

8 days

Reaction after incubation

Technique

Approx. pH. 8 .

Amount of Distillate

Direct Distillation

$650 \mathrm{ccs}$.

Indol Yield (Colorimetric)

0.032886 grms.

Distillation Residue

24.23 grms.

The changes in colour, odour, and reaction in

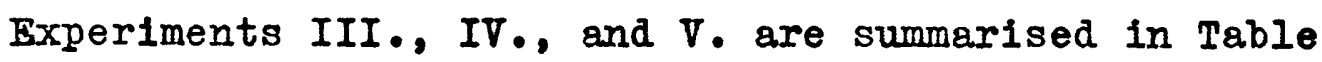
4. 
TABIE 4.

\begin{tabular}{|c|c|c|c|c|}
\hline EXP. & TIME. & COLOUR. & ODOUR. & $\begin{array}{l}\text { REACTION } \\
\text { Approx. pH. }\end{array}$ \\
\hline III. & $\begin{array}{c}\text { Before } \\
\text { incubation }\end{array}$ & Red & Fresh & 10. \\
\hline IV. & n & $"$ & $"$ & 10. \\
\hline $\mathrm{V}$. & $"$ & $"$ & $"$ & 10. \\
\hline III. & $\begin{array}{c}\text { After } \\
\text { incubation } \\
\text { 2nd. Day }\end{array}$ & $\begin{array}{l}\text { Redaish } \\
\text { Brown }\end{array}$ & $\begin{array}{c}\text { Putrefactive } \\
\mathrm{H}_{2} \mathrm{~S}\end{array}$ & 6.5 \\
\hline IV. & $"$ & $n$ & $n$ & 6.5 \\
\hline V. & $"$ & $n$ & $n$ & $6: 5$ \\
\hline III. & 3rd. Day & $\begin{array}{l}\text { Iight } \\
\text { Brown. }\end{array}$ & $\begin{array}{c}\text { Putrefactive } \\
\mathrm{H}_{2} \mathrm{~S}\end{array}$ & 7. \\
\hline IV. & n & $n$ & $n$ & 7. \\
\hline V. & $"$ & $n$ & ห & 7 \\
\hline III. & 5th. Day & Brown & $\begin{array}{c}\text { Putrefactive } \\
\mathrm{H}_{2} \mathrm{~S}\end{array}$ & 7. \\
\hline IV. & $"$ & $"$ & " & 7. \\
\hline $\mathbf{V}$ & $n$ & $"$ & $n$ & 7. \\
\hline III. & 6th. Day & $\begin{array}{l}\text { Dark } \\
\text { brown }\end{array}$ & $\begin{array}{c}\text { Putrefactive } \\
\mathrm{H}_{2} \mathrm{~S}\end{array}$ & 7.5 \\
\hline IV. & n & $\begin{array}{r}\text { Darker } \\
\text { browm }\end{array}$ & $n$ & 8. \\
\hline $\mathbf{V}$. & $n$ & $\begin{array}{l}\text { Dark } \\
\text { brown }\end{array}$ & $n$ & 7 \\
\hline III. & 8th. Day & $\begin{array}{l}\text { Dark } \\
\text { brown }\end{array}$ & $\begin{array}{c}\text { Putrefactive } \\
\mathrm{H}_{2} \mathrm{~S}\end{array}$ & 8. \\
\hline IV. & $n$ & $\begin{array}{l}\text { Darker } \\
\text { brown }\end{array}$ & $n$ & 8. \\
\hline $\mathbf{\nabla}$ & " & $\begin{array}{l}\text { Dark } \\
\text { brown }\end{array}$ & $"$ & 8. \\
\hline
\end{tabular}

Descr1ptive Comments on Experiments III., IV., \& V.

From the results of these three experiments the changes in/ 
in colour, odour, and reaction are seen to present a degree of apparent constancy both in sequence and in intensity.

The quantitative findings revealAconstant relationship between the yield of indol and the amount of the distillation residue. In Experiment III., where the yield of indol is greatest, the amount of the distillation residue is least. In Experiment IV., where the yield of indol is least, the amount of the distillation residue is greatest.

In the following five experiments the same technique was adopted as in the preceding three, the only difference being that larger quantities of meat and water were used. Experiments VI., VII., and VIII. were performed at the same time and under identical conditions.

EXPERIMENT VI.

Yeat

Dater

Sodium Carbonate (Saturated)

Inoculated Mixture

Reaction before Incubation

Incubation Period at $40^{\circ} \mathrm{C}$

Reaction after Incubation

Technique

Amount of Distillate

Indol Yield (Colorimetrio)

Distillation Residue
200 grms. (k1lled 6 days $1000 \mathrm{cos}$. previously) $40 \mathrm{ccs}$. $10 \mathrm{ces}$. Approx. pH.10. 8 days Approx - pH. 8 . Direct Distillation

$1,360 \mathrm{ccs}$. 0.09112 grms. 66.625 grms. 
EXPER IMENT VII.

Meat

Water

Sodium Carbonate (Saturated)

Inoculation Mixture

Reaction before Incubation

Incubation Period at $40^{\circ} \mathrm{C}$

Reaction after Incubation

Technigue

Amount of Distillate

Indol Yield (Colorimetric)

Distillation Residue

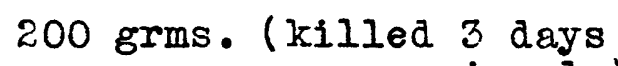

EXPER IMEATT VIII.

Meat

\section{Nater}

Sodium Carbonate (Saturated)

Inoculation Mixtare

Incubation Period at $40^{\circ} \mathrm{C}$

Reaction after Incubation

Technigue

Amount of Distillate

Indol Yield (Colorimetrio)

Distillation Residae

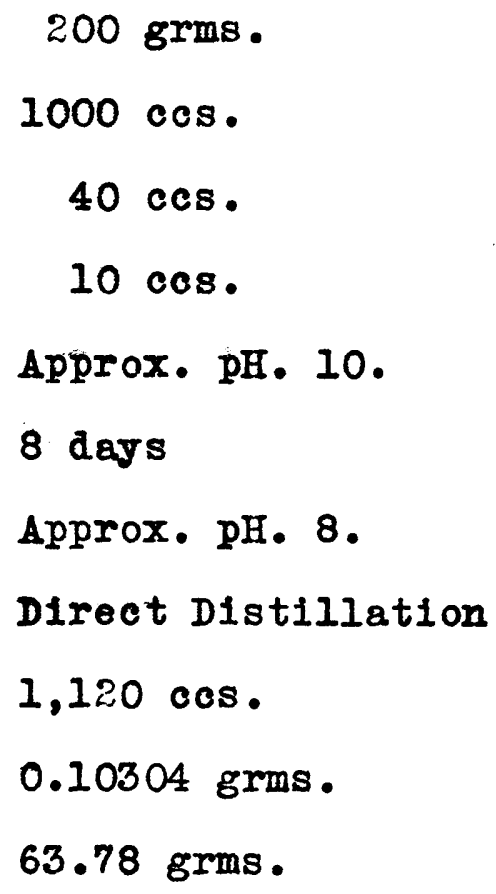

Descriptive Comments on Experiments VI., VII., \& VIII.

The changes in colour, odour, and reaction throughout the/ 
the perlod of incubation in these experiments were similar to those already described in Experiments III., IV, and V.

The quantitative findings reveal the same general relationship between the yield of indol and the amount of the distillation residue. In Experiment VII., where the indol is greatest, the amount of the distillation residue is least. In Experiment VI., where the yield of indol is least the amount of the distillation residue is greatest.

Experiments $X$. and $X$. were carried out synchronously and under identical conditions.

EXPER IMENT IX.

Meat

Water

Sodium Carbonate (Saturated)

Inoculation Mixture

Reaction befere Incubation

Incubation Period at $40^{\circ} \mathrm{C}$

Reaction after Inoubation

Teohntoue

Amount of Distillate

Indol Yield (Colorimetric)

Distillation Residue
200 grms.

$1000 \mathrm{ccs}$.

40 ocs.

$10 \mathrm{ccs}$.

Approx. pH. 10.

8 days

Approx. pH. 8 .

Direct Distillation

$1,430 \mathrm{ccs}$.

0.06864 grms .

$65.625 \mathrm{grms}$. 
EXPER IMENT $X$.

Meat

200 grms.

Water

$1000 \mathrm{ces}$.

Sodium Carbonate (Saturated)

$40 \mathrm{ccs}$.

Inoculation Mixture

$10 \mathrm{ccs}$.

Reaction before Incubation

Approx. pH. 10.

Incubation Period at $40^{\circ} \mathrm{C}$

8 days

Reaction after Incubation

Approx. pH. 8 .

Technique

Direct Distillation

Amount of Distillate

$1,120 \mathrm{cs}$.

Indol Yield (Colorimetric)

0.06384 grms.

Distillation Residue

67.14 grms.

\section{Descriptive Comments on Experiments IX. and $X$.}

The changes in colour, odour, and reaction were similar to those in Experiments III. - VIII. although the actual yield of indol in these two experiments is considerably less than that in either VI., VII. or VIII. A similar relationship is seen to exist between the yield of indol and the amount of the distillation residue.

The following table summarises the essential quantitative results from the preceding experiments (III. - X.).

TABISE 5.1 
TABIE 5 .

\begin{tabular}{l|c|c|c|c}
\hline EXP. & DURATION. & $\begin{array}{c}\text { MEAT } \\
\text { Grms. }\end{array}$ & $\begin{array}{r}\text { INDOL Grms. } \\
\text { (colorimetric } \\
\text { Hie thod })\end{array}$ & $\begin{array}{c}\text { DRIED } \\
\text { RESIDUE } \\
\text { Grms. }\end{array}$ \\
\hline III. & 8 days & 100 & 0.04416 & 22.52 \\
\hline IV. & $n$ & 100 & 0.02340 & 32.25 \\
\hline V. & $n$ & 100 & 0.032886 & 24.23 \\
\hline VI. & $"$ & 200 & 0.09112 & 66.625 \\
\hline VII. & $"$ & 200 & 0.11205 & 49.77 \\
\hline VIII. & $"$ & 200 & 0.10304 & 63.78 \\
\hline IX. & $"$ & 800 & 0.06864 & 65.625 \\
\hline X. & $n$ & 200 & 0.06384 & 67.14 \\
\hline
\end{tabular}

Discussion of Results in Experiments III. - X.

The period of incubation of the meat mixtures is seen to be associated with changes in colour, odour and reaction which present a degree of constancy rather than variability under the experimental conditions described. The distillation of the meat mixtures at the conclusion of the period of incubation is associated with the presence, in the distillate, of indol in an amount which is proportionate to the amount of meat subjected to putrefaction and in an amount which bears a relationship to the amount of the dried meat residue remaining after distillation.

Comparison of the quantitative findings in each experiment shows variability rather than constancy. For example the amount of indol produced in a mixture of 100 grms. of macerated meat and $500 \mathrm{cos}$. of water and $20 \mathrm{ccs}$. of aatirated sodiun carbonate after elght days' incubation at $40^{\circ} \mathrm{C}$ is seen to vary from $0.0234 \mathrm{grms}$. (in Experiment IV) tol. 
to 0.04416 grms. (In Experiment III.), the average yield from Experiments III., IV., and $\nabla$. being 0.033482 grms. The amount of indol produced in a mixture of $200 \mathrm{grms}$. of macerated meat and $1000 \mathrm{ccs}$. of water and $40 \mathrm{ccs}$. of saturated sodium carbonate after eight days' incubation at $40^{\circ} \mathrm{C}$ is seen to vary from $0.06384 \mathrm{grms}$. (in Experiment $x_{.}$) to 0.11205 grms. (in Experiment VII.), the average yield of indol in Experiments VI., VII., VIII., IX., and $X$. being 0.08774 grms.

Salkowski found that the amount of indol produced in a mixture of $2000 \mathrm{grms}$. of macerated-horse flesh and 8000 ccs. of water after eight days' incubation at $40^{\circ} \mathrm{C}$ vuried from 0.820 grms. to 0.900 grms. in three experiments. On the basis of his results the proportionate yield of indol from 100 grms. of horse flesh would therefore vary from 0.041 to 0.045 grms. Salkowski did three experiments on horse-flesh of eicht days' incubation and in these, the average proportionate yield of indol per $100 \mathrm{grms}$. of horse-flesh used, was 0.043 . The figures representative of indol gield for 100 grms. of meat after putrefaction for eight days obtained in Experiments III. to $X$. thus correspond with those of Salkowski.

In each of the preceding Experiments III. - $X$. almost Identical changes in colour, odour and reaction were observed. The amounts of indol yielded in each experiment differed within a relatively small range. In each instance, the quantity of indol was seen to bear a constant relationship to the amount of the distillation residue. From these observations it may be deduced that when mixtures of meat and/ 
and water of similar composition are exposed to autoinfection from the air, they tend to undergo similar qualitative and to a lesser extent similax quantitative changes. 


\section{BIBIIOGRAPHY (SECTION I.D.)}

(1) SAIKOWSKI, E.: Practicum der Physiologischen und Pathologischen Chemie. 1912, 228. Berlin: Verlag Von August Hirschwald.

(2) ZOLIER, H.F.: Jour. Biol. Chem. Xli,25.

(3) NONNOTTE, M. \& R. DELANCHE: Compt. rend. Soc. biol. $1908,1 \times i v, 658,228$.

(4) ZOLIER, H.F.: Jour. BIOl. Chem. xli, 37 . 
SECTION II.

THE INFLUENCE OF SUGARS ON PUTREFACTION.

A. \#ISTORICAI REVIEW.

When bacterial decomposition of organic matter came to be more fully understood, the possible influence of such processes takinf place both outside and inside the human intestine, upon the health of the individual, natarally demanded consideration. It was known, that, in the adult, conditions conducive to the occurrence of putrefaction were present within the lumen of the intestine, namely water, bacteria, and proteins together with a temperature of about $37^{\circ} \mathrm{C}$. While the investigations of Thierfelder and Nuttal (1) did reveal the fact that animal life was: possible without bacteria in the intestine, the experiments of Schottelius (2) on chickens showed that sterile conditions within the bowel led to an imparment of growth assoclated with debility. The latter investigation also proved that the addition of certain intestinal bacteria to the food at once gave rise to amelioration of those conditions.

It was subsequently recognioed that wile the healthy life of the animal was dependent, to some extent, upon the presence of bateria within the intestine, the bacterial decomposition of protein matter in such a situation was always to be regarded as a possible source of toxaemia. Means of detecting and preventing such a condition were consequently sought for. From the therapeutic standpoint, there were several lines of approach to such a subject which centred on the presence of the primary conditions in the process concerned, namely, Iivinel 
living bacteria on the one hand and protein-containing material, on the other. Without one or other of these two factors there could be no putrefaction either inside or outside the intestine. On the basis of this conception, the lumen of the intestine represented an environment which, as regards heat and moisture, could not be influenced therepeutically to any appreciable extent. The only two alterable elements lay in the presence or absence of bacteria and of food protein. It seemed that these two elements might be controlled therapeutically. For example:

1. Bacteria might be killed by administration of bactericial substances, on the antiseptic principle.

2. Protein in the food might be, excluded, diminished, or modified by the presence of other essential elements in diet such as carbohydrates, fats, or minerals, on the dietetic principle.

Bouchard (3), following the antiseptic prinoiplo, was one of the first to take the former course in attempting to disinfect the intestines by pharmaceutical means. With regard to the latter course, it was obvious that protein, being an essential food, could not be excluded from diet in order to prevent intestinal putrefaction. Diminution of protein could only be relative and subject to the metabolic requirements of the individual. Modification, by the presence of other essential elements in diet, represented the most hopeful therapeutic aspeot of the dietetic principle. Muller (4) and Ortweiller (5) were among the first to recommend the pursuance of this partioular aspect of the dietetic principle by their observations upon the influence of the carbohydrates upon protein decomposition. Meanwhile Hirschler (6) in 1886 had/ 
had observed that cane sugar had an inhibitory influence upon the putrefoction of meat as indicated by the absence indol production.

In 1888 Bey (7) recommended sugar syrup for the treatment of burns. In the same year Bujwid (8) found that staphyloccus pyogenes aureus, in the presence of a sugar solution, lost its capacity to form pigment. Some years later, Auerbach (9) showed that certain bacteria lost their proteolytic power in a sugar containing medium. Fischer (10) was of the opinion that various transudates and exudates could be preserved for considerable periods after the adition of a 25\% sugar solution. Blermacki (11) and Eisenstadt (12), however, were of the opinion that the carbohydrates only axercised a slight inhibitory action on intestinal putrefaction. The souring of milk provided the commonest example of an inhibitory influence upon putrefaction by the presence of other food elements. The influence of milk diet in reducing intestinal putrefaction was recognised by Poehl (13), Biernacki (14), Winternitz (15), Rennert (16), Skorodumow (17), Albu (18), and others. Simitzki (19) attributed the inhibitory influence of milk to the following factors:-

1. To the natural resistance of casein to putrefactive cleavage.

2. To the action of milk sugar.

3. To the action of lactic acid derived from milk sugar. Backmann (20), and Hirschler (2I), stated that fat played no part in this inhibitory influence of milk and Indicated that its presence actually faroured putrefaction. One of the first clues to the mechanism of the phenomenon of the inhibition of putrefaction by sugars was furnished by the work of Bienstock (22) in 1900. He observed in the/ 
the course of his stuaies in B.putreficus that the activity of this proteolytic organism was inhibited by the presence of $B$. coll communis and B. lactis aerogenes, especially in the presence of sugar. This inhibitory action, Bienstock attributed to an antagonstic force (force antagonistiquiei on the parts of these two organisms. The subsequent work of Tissier and Martelly (23) confirmed the presence of an antagonistic force on the part of sugar ferments towards peptolytic ferments in the presence of sugar. They demonstrated further, however, that this was due essentially to the acias produced by fermentation of the sugar.

In 1903 Simitzk1 (24) found that lactose, glucose, galactose and mannite each exerted varying degrees of inhibition upon the putrefaction of horse-flesh. Simitzki's experiments, to which further reference will be made, are of special interest in view of their quantitative results.

Within more recent years Kendall (25) and his colleagues have found that the presence of abondance of carbohydrates may largely prevent the formation of certain nitrogenous end-products in culture media. For example, these workers ( $25 a$ ) have recorded the observation that the presence of glucose, in a gelatine culture of B. proteous, prevented formation of proteolytic enzymes, until complete fermentation of the glucose had taken place. In this connection, the following table illustrative of Kendall's work upon the influence of sugars on bacterial media is quoted by Hells (26). 


\begin{tabular}{|l|c|c|}
\hline Organism & $\begin{array}{c}\text { Significant Product } \\
\text { in Protein Medium }\end{array}$ & $\begin{array}{c}\text { Significant Change } \\
\text { in Carbohydrate and } \\
\text { Protein Medium. }\end{array}$ \\
\hline $\begin{array}{c}\text { Diphtheria } \\
\text { Bacillus }\end{array}$ & $\begin{array}{c}\text { Soluble Dyphtheria } \\
\text { Toxin }\end{array}$ & $\begin{array}{c}\text { Iactic Acid } \\
\text { no Toxin }\end{array}$ \\
\hline $\begin{array}{c}\text { Shiga Bacillus } \\
\text { Bacillus Coli }\end{array}$ & Soluble Shiga Toxin & " Indol \\
\hline Bacillus Proteins & $\begin{array}{c}\text { Soluble Proteolytio } \\
\text { Bnzyme }\end{array}$ & $\begin{array}{c}\text { no Indol } \\
\text { no Bnzyme }\end{array}$ \\
\hline
\end{tabular}

Raistrick (27) has criticised the fact that Kendall and his colleagues regarded ammonia formation as an index of protein decomposition. Ralstrick considers that the amino-acid nitrogen is the best index of protein and amino-acid decomposition and, on the basis of his estimation of amino-acid nitrogen in bacterial decomposition, he offered the following explanation of the action of carbohydrates in putrefactive mixtures:-

"Bacteria need for their anabolic processes certain rela"tive amounts of nitrogen and carbon. If the available "N. Is in excess of that amount necessary to combine with "the available carbon for these synthetic purposes, this "N. appears in the form of ammonia; if, however, the amount "of available carbon is in excess of the amount necessary "to combine with the arailable N. for synthesis, no ammonia "appears because all the $\mathbb{N}$. is used for synthesis." Raistrick formed the opinion that the carbohydrates did not actually have a "protein-sparing" effect in the sense suggested by Kendall, but that they actually enabled bacterta to utilise more protein than they would in the absence of carbohydrates.

Stephenson (28) has pointed out that the inhibitive effect/ 
effect of carbohydrate on indol production may be due to several causes:-

1. The oxidative activity of the cell may be diverted from the side/chain of the tryptophan to the carbohydrate.

2. The course of the breakdown of the side-chain may be altered so that indol-acetic-acid is formed, which does not form indol.

3. The presence of the carbohydrate may enable the cell (either by stimulation of growth or otherw1se) to breakdown the indol nuelens so rapidly that detectable amounts of indol never accumulate.

As far as can be ascertained, the problem of the mechanism of the inhibition of putrefaction by sugars is still unsolved. From the practical standpoint, the fact temains that sugars possess a definite influence upon the course of putrefaction. 


\section{BIBLIOGRAPHY. (SECTION II.A.)}

(1) THIERFEIDER, \& NUTTAL: Ze1t. f. phys101. Chem. Bd. xxi, S.109, and Bd. $\mathrm{xx} 11, \mathrm{~S} .62$.

(2) SCHOTmELIUS, : Archiv. f. Hygiene, Bd.34 and 40.

(3) BOUCHARD, : Gaz. hebaom. de méd. et chir. 1884, Nr.21; Bull. de la Soc. de Biol. 1884, and Leçons sur les autointoxiations. 1887 . Paris.

(4) MULIER, : Mitteilungen der Würzburger medizinschen KIInik, Ba. 2, S. 342 .

(5) ORTWEITER, : Mitteilungen der Wurzburger medizinschen Klinik, Bd. 2, S. 153.

(6) HIRSCHLER, : Über den Einfluss der Kohlehydrate auf die Eiweissfäulnis. Zeit. 1 . physiol. Chem. 1886, Bd.x, S. 306 .

(7) BEY, J.: Révue génér. de clin. et de therapeutique. 31 Ma1 1888.

(8) BUJWID, : Centralblatt I. Bakteriologie. 1888, Bd.2, S.588.

(9) AUERBACH, : Archir f. Hygiene. 1899, Bd. 31, S.311.

(10) FISCFER, : ZeIt. I. Chirurgie. Bd. 22. S.225.

(1I) BIERNACKI, : Deutsches Archivf. klin. Jerizin. Bd. 49; Medicinskoe Obosr. 1891, Nr. 31.

(12) EISENSTADT, : Archiv f. Verdauungskrankheiten. Bd.3, $\mathrm{s} .155$. 
(13) POEHI, : Petersburger med. Wochenschrift. 1887, Nr. 50 .

(14) BIERWACKI, : Deutsches Archiv f. klin. Yedizin. Bd. 49 ; liedicinskoe Obosr. 1891, Nr.31.

(15) WINTERNITZ, : Zeit. f. phrsikalische Chem. 1892, S.460.

(16) REATVER, : Über den Einfluss der gasierten und nichtgasierten Milch auf die Darmgämung des gesunden Menschen. St.Petersburger Dissertation. 1893.

(17) SKORODUnow, : Über den Einfluss der Milichaiat auf die Darmfäulnis bei gesunden Menschen. St. Petersburger Dissertation. 1895.

(18) ALBU, : Deutsche med. Wochenschr. 1898, Nr. 32.

(19) SINITZKI, S.: 'Beitrag zur Iehre des Einflusses der Kohlehyarate auf die Eiwe1ssfäalnis." Zelt. f. phys101. Chem. 1903, 20xix, 99.

(20) BACKILNN, : Zeit. f. klin. Medizin. Bd. 44, S.458.

(21) HIRSCHLER, : T̈ber den Einfluss der Kohlehydrate auf die Eiweissfäulnis. Zeit. f. physiol. Chemb. 1886, Bd.X, S.306.

(22) BIENSTOCK, B.: 'Ueber ale Bakterien der roeces.' ze1t. f. klin Med. 1884, xiii.

(23) TISSIER, H. \& H.N.MARTELIY: Recherches sur la Putréfaction de la Viande de Boucheri. Annales de I'Institut Pasteur. 1902, 
(24) SIlivITZKI, S.: 'Beitrag zur Lehre des Einflusses der Kohlehydrate auf die Eiweissfäulnis.' Zeit. f. physiol. Chem. 1903, xxxix, 99.

(25) KWWIDALI, A.I. and FARMER: Jour. Biol. Chem, 1912 xii, $10,19,215,465,469$. Jour. Biol. Chem. 1913, xi11, 63.

(25a) KENDALI, A.I. A.W.WhLKRR: "Observations on the proteolytic enzyme of 'Bacillus proteus.' 1915." Jour. Inf. Dis xvi1, 442 .

(26) WELIS, H.G.: Chemical Pathology. 5th ed., 112. Philadelphia and London: W.B.Saunders Company.

(27) RAISTRICK, H.: 'A quantitative study of the Aerobic Decomposition of Tryptophan and Tyrosine by Bacteria.' Studies on the cycloclastic Power of Bacteria. Part 11, 79. (From the Biochem. Jour. $x \nabla(1), 1921)$.

(28) STEPHENSON, M.: Bacterial Metabolism. 1930, 209. Iondon: Iongmans, Green \& Co. 
SECTION II.

\section{THE INFLUENCE OF SUGARS ON PUTREFACTION.}

\section{B. REVIEWW OF SIMNITZKI'S EXPEERIMENTS.}

In order to define the mode of action of the various sugars on putrefaction Simitzki (1), in 1903, carried out a series of experiments. He based his experiments on the earlier work of Hirsohler and Salkowski. Simitzk1's work is of interest since he hade comprehensive quantitative analyses of sulphuretted hydarogen, ammonia, indol, phenol, volatile and non-volatile acids, and of the residual undecomposed albumen in meat mixtures containing different percentages* of lactose, glucose, galactose, and mannite, which had been incubated at $40^{\circ} \mathrm{C}$ for varying periods. His control mixture contained 125 grms. of finely macerated lean meat, $20 \mathrm{ccs}$. of saturated sodium carbonate solution and $1000 \mathrm{ccs}$. of water. Various sugars in amounts ranging from 6.25 to 12.5 grms. were added to meat mixtures of the same composition as the controls and these vere subsequently inoculated with $40^{\circ} \mathrm{cos}$. of a putrefactive mixture according to the technique of salkowski, which was adopted throughout the experiments.

I have summarised Simnitzki's findings and have recorded them in diagrammatic form so that they may be more readily surveyed. Diagrams (1) to (8)^represent his experimental results on the influence of lactose, gluoose, galactose, and mannite on putrefaction of meat. Diagram (9) represents his average findings in the control mixtures. The shadec portion in each diagram represents the undecomposed albumen in each oase. In the unshaded portion, I have enumerated Simnitzki's quantitative findinga of the substancederived from the albumen which has been decomposed. 
Fic V

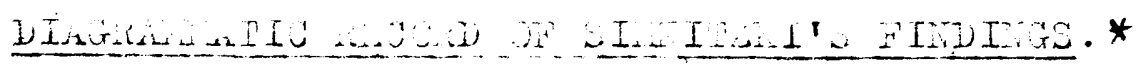

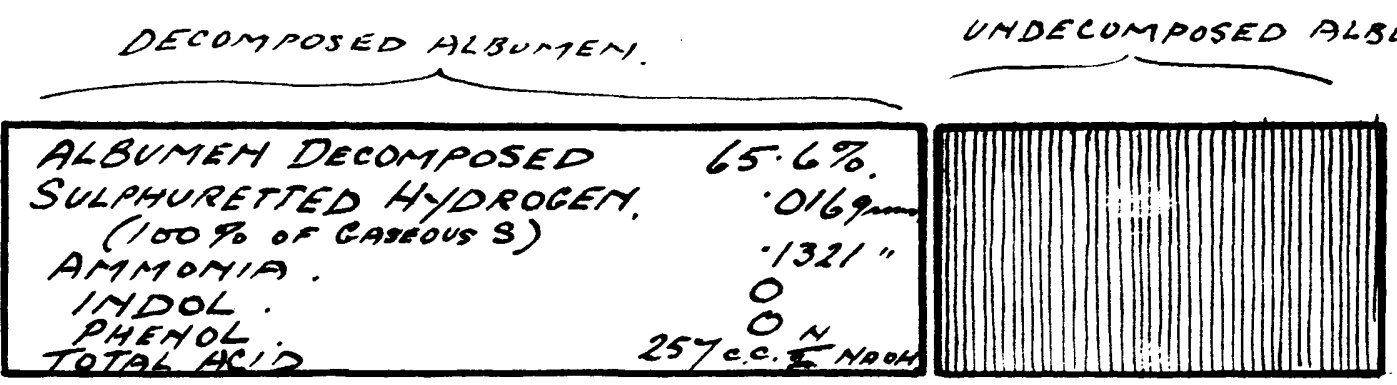

Licosose

$50 \%$

(2)

4 Dsys

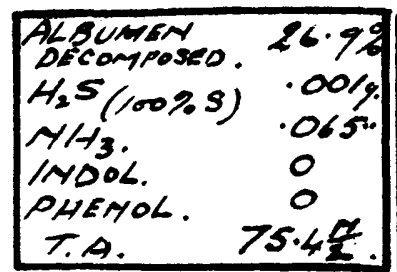

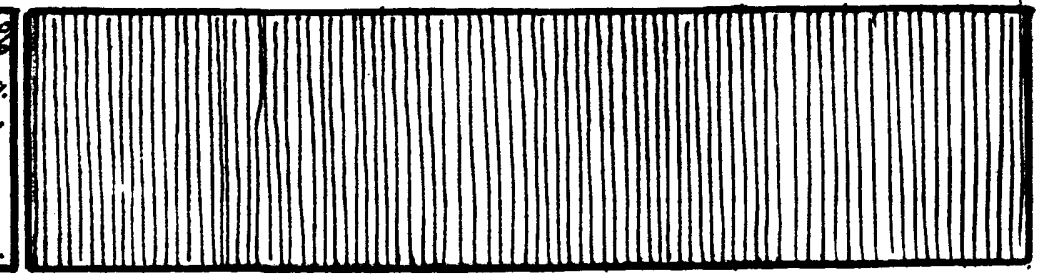

(3)

Iactose

sis

4 Dajs

ALBUMEN DECOMPOSED
H.S. (98\% S)
YHS
IMBOLL.
PHEMOL.
TAS

$74 \%$

- 04868na

$.644 "$

.043.

.044 .

205.4 N Mod

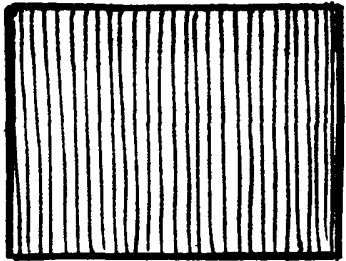

Glacose

50

(4)

4 Days

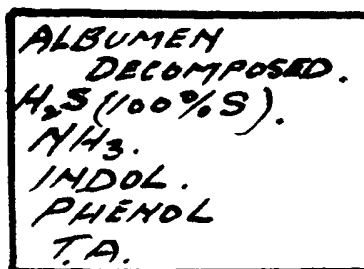
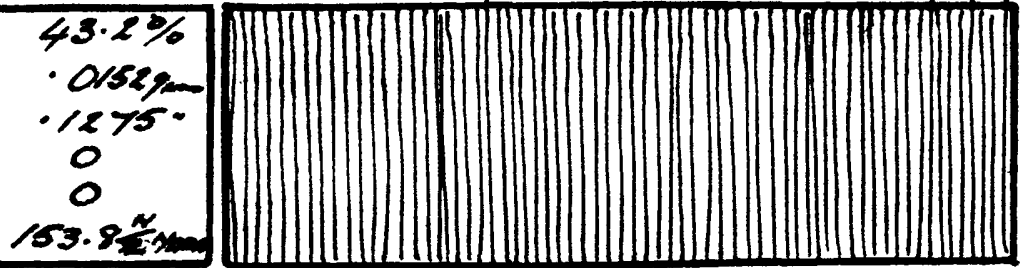

- Glucose

(5)

$$
\therefore 540
$$

4 Days

ALBUMEY DECOMPOSED.
HAS.
YHB
INDOLL
PHEMOL.
T.A.
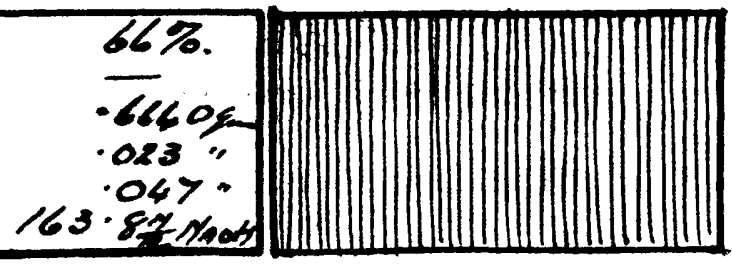

Galectose

(6) $50 \%$

\begin{tabular}{|c|c|}
\hline $\begin{array}{l}\text { ALBUMEN DECOMPOSED } \\
\text { H/2S (6Z.2\%.S) } \\
\text { NHB. } \\
\text { IADOL. } \\
\text { PMENOL. } \\
\text { T.A. }\end{array}$ & $\begin{array}{l}76.08 \% . \\
.0198900 . \\
.5902 " \\
.003 " \\
.0154 " \\
212.6 \frac{4}{2} \text { Noon. }\end{array}$ \\
\hline
\end{tabular}

4 Days

In his origingl article simitrki record his figures in * table form only. I have devised the above method of representation, with a view to fumishing a graphjo ss well as a qualitativé conception of his findings. 


\section{DIAGRAMIATIC RECORD OF SIMTITZKI'S FINDINGS (Continued)}

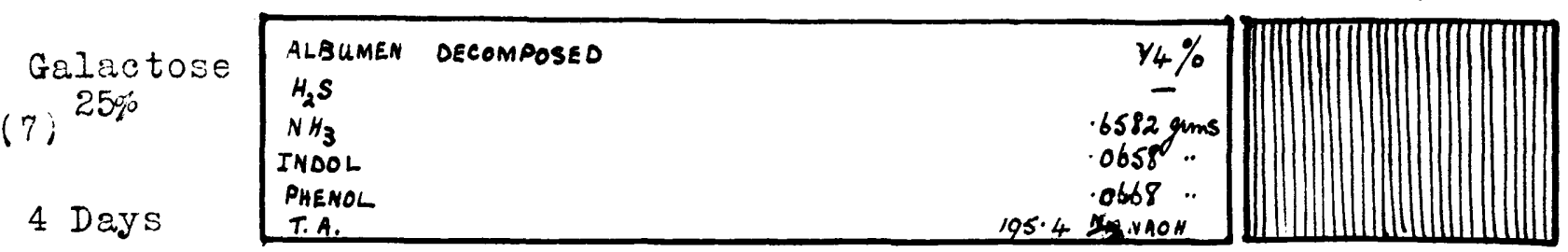

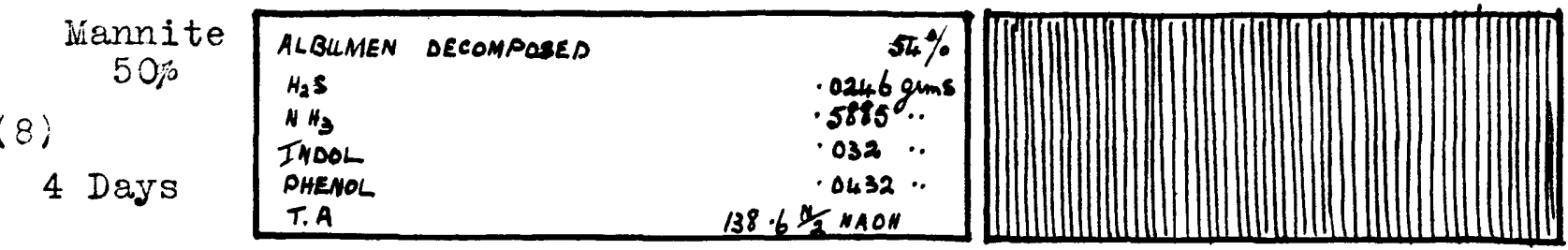

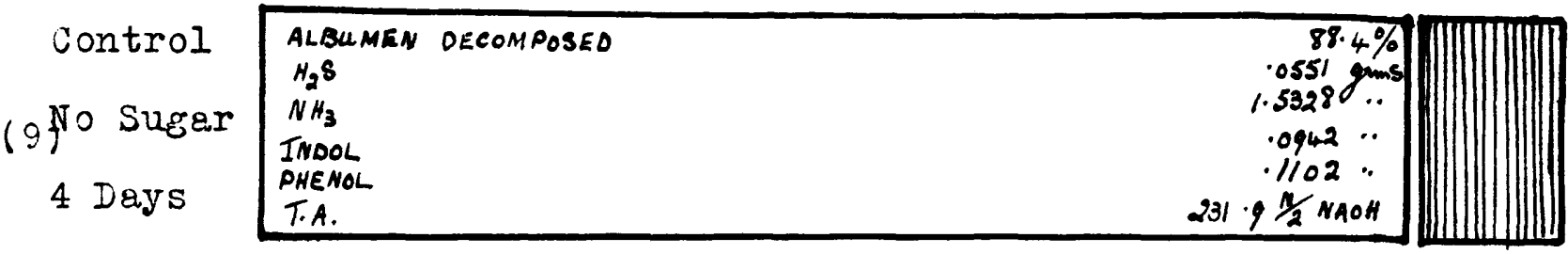

Comments of Diagrams $1-9$.

From the above diagrams, it is seen that the most striking example of the inhibitory influence of sugar on bacterial decomposition of albumen is to be found in the case of the meat mixture containing $50 \%$ lactose, Diagram (2), incubated for 4 days at $40^{\circ} \mathrm{C}$. In this case, only $26.9 \%$ of the original albumen was decomposed. No indol and no phenol were formed. The amounts of sulphuretted hydrogen, ammonia, and total acids were lower than in any of the other sugar and meat mixtures. A general survey of Simitzki's figures reveals a consistent relationship between the percentage of albumen decomposed and the formation of sulphuretted hydrogen, ammonia, indol, phenol, and total acids. 
Summary of Simnitzki's Findings.

On the basis of his results, Simitzki arrived at the following conclusions:-

"1. That the decomposition of sugar and albumen in putrefying mixtures commenced simultaneously but ald not proceed at an equal rate.

2. That the presence of sugar inhibited the decomposition of albumen by bacteria and that the quantity of albumen decomposed was in inverse ratio to the amount of sagar used.

3. That different kinds of sugar exercised a different influence. The inhibitory influence of 50; lactose was greater than that of glucose or galactose. The influence of glucose again was greater than that of galactose.

4. That the inhibitory influence on putrefaction possessed by various sugars was associated with the acias formed as a result of fermentation. In this connection, lactic acid and its salts apparently played an important part. 5. That, in the presence of sugar only, the first patrefaction phase took place in the mixture (Phase des ferments mixtes of Tissier and Martelly). The development of ammonia was sufficient to neutralise the excess acidity resulting from the fermentation of the carbohydrates."

One of the essential points of interest, arising from Simitzki's findings, lies in the fret that when sugar was added to mixtures of meat and water of similar composition and infected from the air, definte quaritititive changes took place which differed in the afferent mixtures accordth to the type and the amount of sugar used. 


\section{SECTION II.}

THE INFLUENCE OF SUGARS ON PUTREFACTION:

\section{EXPER IMEANTS.}

The experiments deseribed in this section contain observations which I have made upon the influence of various sugars on putrefaction, based on the work of Simnitzki and Salkowski. The experiments were carried out in conjunction with those previously described in section I. of this thesis.

\section{EXPERIMGNT II.}

THE DNFLUENCE OF IIACTOSE ON A MIXYURE OF MACERATED OX-FIESH AND HATER.

Technique.

The experimental technique adopted was that of simnitzki and of Salkowski.

A meat mixture containing the following ingredients was placed in a flask of 1 litre capacity.

Macerated Ox-1lesh.

Water

Sodium Carbonate (Saturated)

Lactose

Inoculation Mixture

$$
62.5 \text { grms. }
$$
$500 \mathrm{ccs}$. $20 \mathrm{ccs}$. $6.25 \mathrm{grms}$.

5 ces.

This Ilask was designated A.

Another mixture was prepared containing the same ingredients as above, with the exception of lactose. This flask was designated $B$. and was used as a control. The amount of lactose added to flask $\Lambda$. represented $50 \%$ in proportion to the approxinate amount of protein present in the meat. On the assumption that the meat containad $20 \% 1$ 
$20 \%$ of protein, 62.5 grms. of meat, therefore, represented 12.5 grms. of protein approximately. The lactose was added to flask A. immeiately after its contents had been prepared and prior to the addition of the inoculation mixture. The reaction of the contents of flask A. was approximately $\mathrm{pH}$. 10., that of flask B. was also approximately pH. 10. Both flasks were then corked and placed in the incubator at $40^{\circ} \mathrm{C}$. for 4 days. At the end of this period, both flasks were removed from the incubator.

Observations as to colour, odour, and reaction are recorded in the following table:-

TABLE 6.

\begin{tabular}{c|c|c|c}
\hline FIASK & COLOUR & OD OUR & $\begin{array}{c}\text { RFACTION } \\
\text { Approx. pH. }\end{array}$ \\
\hline (Meat + A. lactose) & Pale brown & $\begin{array}{l}\text { Slightly } \\
\text { pungent }\end{array}$ & 5.5 \\
\hline $\begin{array}{l}\text { B. } \\
\text { (Meat. Control) }\end{array}$ & Dark brown & $\mathrm{H}_{2}$ S strong. & 8. \\
\hline
\end{tabular}

Descriptive Comments on Table 6.

The pale colour, the absence of a putrefactive odour and the marked change in reaction, indiative of a higher degree of acidity than in the case of llask $B_{.}$, were considered noteworthy.

Technique continued:-

The contents of both llasks were then subjected to steam distillation and the distillates were subsequently treated according to the technique of salkowski.

$500 \mathrm{ccs}$. of distillate were recovered from each flask. Samples Irom each aistillate were tested qualitatively for Indol and phenol. Negatire reactions for indol and phenol were/ 
were obtained in the case of the distillate from the meat and lactose mixture. Positive reactions for both these substances were obtained from the distillate of the control mixture.

TABIE 7 .

\begin{tabular}{c|c|c|c|c|c}
\hline FLASK & $\begin{array}{c}\text { MEAT } \\
\text { Grms. }\end{array}$ & $\begin{array}{c}\text { IACTOSE } \\
\text { Grms. }\end{array}$ & $\begin{array}{c}\text { INCUBATION } \\
\text { Days }\end{array}$ & IND OI & PHEM OI \\
\hline A. & 62.5 & 6.25 & 4 & - & - \\
\hline B. & 62.5 & 0. & 4 & + & + \\
\hline
\end{tabular}

Summary of Experiment XI.

The presence of lactose $(50 \%)$ in a mixture containing 62.5 grms. of meat and $500 \mathrm{ccs}$. of water after 4 days' incubation at $40^{\circ} \mathrm{C}$ was thus seen to be associated with the absence of the usual dark brown colour, the absence of the odour of sulphuretted hydrogen, and the absence of an alkaline reaction together with the complete inhibition of indol and phenol.

\section{EXPER TULATT XII.}

\section{THE INFLUENCB OF GLUCOSE ON A MUTURE OF OX-FLESH AND WATER.}

Two meat mixtures were prepared each containing the same ingredients as in the previous experiment. $6.25 \mathrm{grms}$. of glucose were added to one of the mixtures designated $c$. The control mixture was afignated $D$. The reaction in both cases was approximately pH. 10. Both flasks were incubated at $40^{\circ} \mathrm{C}$ for 4 days. At the end of this period the following points were noted:- 
TABLE 8.

\begin{tabular}{c|c|c|c}
\hline FIASK & COLOUR & ODOUR & $\begin{array}{c}\text { REACTION } \\
\text { Approx. pH. }\end{array}$ \\
\hline (Meat $f$ lucose & Pale brown & Pungent & 5.5 \\
\hline (Meat. \begin{tabular}{l} 
Dontrol) \\
\hline
\end{tabular} & Dark brown & $\mathrm{H}_{2} \mathrm{~S}$ strong & 8. \\
\hline
\end{tabular}

Descriptive Comments on Table 8.

The above features of the mixtures were thus similar to those of flaiks $A$. and $B$. In the prececing experiment.

Technique continued:-

The contents of both flasks were then subjected to steam distillation and samples from each distillate were tested for indol and phenol. Negative reactions for both Indol and phenol were obtained in the case of the distillate from the meat and glucose mixture. Positive reactions for these two substances were obtained from the distillate of the control. ixture.

TABLE 9 .

\begin{tabular}{c|c|c|c|c|c}
\hline FIASK & $\begin{array}{c}\text { MRAT } \\
\text { Grms. }\end{array}$ & $\begin{array}{c}\text { GIUCOSE } \\
\text { Grms. }\end{array}$ & $\begin{array}{c}\text { IITCUBAFIOI } \\
\text { Days }\end{array}$ & IMDOI & PHETOI \\
\hline C. & 62.5 & 6.25 & 4 & - & - \\
\hline D. & 62.5 & 0. & 4 & + & + \\
\hline
\end{tabular}

\section{Summary of Expertintit 2II.}

The presence of gluoose $(50,5)$ in a mixture containing 62.5 grms. OI meat and 500 c.08. of water after 4 days' incubation/ 
incubation at $40^{\circ} \mathrm{C}$ was thus seen to be associated with the absence of the usual dark brown colour, the absence of the odour of sulphuretted hydrogen, and the absence of an alkaline reaction together with the complete inhibition of indol and phenol.

\section{EXPERIIUENT XIII.}

\section{THE INFLUENCE OF GATACTOSE ON A MIXTURE OF OX PFIESH AND WATER.}

Two meat mixtures were prepared each containing the same ingredients as before. $\quad 6.25 \mathrm{grms}$. of galactose were added to one of the mixtures designated E. The control mixture was designated $\mathrm{F}$. The reaction in both cases was approximately pH. 10. The mixtures were incubated at $40^{\circ} \mathrm{C}$ for 4 days. At the end of this period the following points were noted:-

TABIE 10.

\begin{tabular}{c|c|c|c}
\hline FIASK & COLOUR & ODOUR & $\begin{array}{c}\text { RFACTION } \\
\text { Approx. pH. }\end{array}$ \\
\hline E. & & & \\
(Meat.t galactose) & Dark brown & $\mathrm{H}_{2} \mathrm{~S}$ & $6 \cdot$ \\
\hline $\begin{array}{l}\text { F. } \\
\text { (Meat. Control) }\end{array}$ & Dark brown & $\mathrm{H}_{2} \mathrm{~S}+$ & 8. \\
\hline
\end{tabular}

Descriptive Comments on Table 10.

In this experiment the colour was darker than in Experiments XI. and XII, the odour of $\mathrm{H}_{2} \mathrm{~S}$ was appreciable in the sugar containing mixture after 4 days' incubation. It is seen/ 
seen also that the reaction was less acid than in Experiments XI., and XII.

Technique continued:-

The contents of both flasks were then subjected to steam distillation and samples from each distillate were tested for indol and phenol. Slightly positive reactions for indol and phenol were obtained in the case of the distillate from the meat and galactose mixture. Positive reactions for both indol and phenol were obtained from the distillate of the control mixture.

TABIE 11.

\begin{tabular}{c|c|c|c|c|c}
\hline FLASK & $\begin{array}{c}\text { MEAT } \\
\text { GrmS }\end{array}$ & $\begin{array}{c}\text { GATACTOSE } \\
\text { Grms. }\end{array}$ & $\begin{array}{c}\text { INCUBATION } \\
\text { Days }\end{array}$ & INDOI & PHEN OI \\
\hline E. & 62.5 & 6.25 & 4 & faint trace & + \\
\hline F. & 62.5 & 0. & 4 & + & + \\
\hline
\end{tabular}

Summary of Experiment XIII.

The presence of galatose $(50 \%)$ in a mixture containing $62.5 \mathrm{grms}$. of meat and $500 \mathrm{ccs}$. of water after 4 days' incubation at $40^{\circ} \mathrm{C}$ was thus seen to be associated with a darker colour, with an odour of sumburetted hydrogen, with a slightly acid reaction, and with the presence of traces of indol and phenol.

\section{EXPERIMENT XIV./}


IXXPER IMENT XIV.

THE INFLUENCE OF MANNITE ON A MDTUURE OF OX FLESH AND MATER.

Weat mixtures were prepared as before. 6.25 grms. of mannite were added to one of the mixtures designated $G$. The control mixture was designated $H$. The reaction was approximately pH. 10. in both cases. The mixtures were incubated at $40^{\circ} \mathrm{C}$ for 4 days. At the end of this period, the following points were noted:-

TABIE 12.

\begin{tabular}{c|l|c|c}
\hline FIASK & COLOUR & ODOUR & $\begin{array}{c}\text { REACTION } \\
\text { Approx. pH. }\end{array}$ \\
\hline G. & & & \\
(Meat $\rightarrow$ inannite) & Dark brown & $\mathrm{H}_{2} \mathrm{~S}$ & 6. \\
\hline H. & & & \\
\hline (Meat. Control) & Dark brown & $\mathrm{H}_{2} \mathrm{~S}+$ & 8. \\
\hline
\end{tabular}

Descriptive Comments on Table 12.

The above features of the mixtures were thus similar to those of flasks $F$. and F. in the preceding experiment. The colour, however, was somewhat darker and the odour of $\mathrm{H}_{2} \mathrm{~S}$ more pronounced.

Technique continued:-

The contents of both flasks were then subjected to steam distillation and samples from each distillate were tested for indol and phenol. Frankly positive reactions for indol and phenol were obtained in the case of the distillate from the meat and mannite mixture. Positive reactions for both indol and phenol were obtained from the distillate of the control mixture. 
TABIE 13.

\begin{tabular}{l|c|c|c|c|c}
\hline FIUASK & $\begin{array}{c}\text { MEAT } \\
\text { Grms. }\end{array}$ & $\begin{array}{c}\text { MANNITE } \\
\text { Grms }\end{array}$ & $\begin{array}{c}\text { INCUBATION } \\
\text { Days }\end{array}$ & IND OI & PHEITOI \\
\hline G. & 62.5 & 6.25 & 4 & $\begin{array}{c}\text { Faint but } \\
\text { stronger } \\
\text { than gal- } \\
\text { actose. }\end{array}$ & + \\
\hline H. & 62.5 & 0. & 4 & + & + \\
\hline
\end{tabular}

\section{Summary of Experiment XIV.}

The presence of mannite $(50 \%)$ in a mixture containing $62.5 \mathrm{grms}$. of meat and $500 \mathrm{ccs}$. of water after 4 days' incubation at $40^{\circ} \mathrm{C}$ was thus seen to be associated with a darker colour, with an odour of sulphuretted hydrogen, with a slightly acid reaction, and with the presence of indol and phenol.

The results of Experiments XI., XII., XIII., and XIV. are summarised in the following table:-

\section{TABIE 14.}

\begin{tabular}{l|c|c|c|c}
\hline SUGAR & $\begin{array}{c}\text { PROPORTION } \\
\text { SUGAR TO } \\
\text { PROTEINS }\end{array}$ & ITDOI & PHENOI & $\mathrm{H}_{2} \mathrm{~S}$ \\
\hline Lactose & $50 \%$ & - & - & - \\
\hline Glucose & $n$ & - & - & - \\
\hline Galactose & $n$ & Very faint & + & + \\
\hline Mannite & $n$ & Faint + & + & + \\
\hline
\end{tabular}


Summary of Experiments XI. - XIV.

1. The influence of the sugars lactose, glucose, galactose, and mannite, in proportions of $5 \%$ to the amount of protein in the meat mixture, upon putrefaction was demonstrated.

2. Lactose and glucose were seen to be apparently of approximately equal poteny in their inhibitory influence upon putrefaction.

3. Galactose was associated with a slight inhibitory action. Mannite was not associated with an appreciable inhibitory action upon putrefaction.

\section{EXPERIMENTS XV. - XVIII.}

THE INFLUENCE OF LACTOSE ON PUTREFACTIVE MIXTURES OVER PROLONGED PERIODS.

In the following experiments, an attempt was made to determine:-

(1) The duration of the inhibitory influence of lactose on indol production.

(2) The extent of the inhibitory influence of lactose as indicated by the quantitative jield of indol and the amount of the distillation residue.

\section{EXPERIMENT XV.}

Two mixtures were prepared and placed in flasks designated $I$. and $J$. respectively, the latter being the control. The flasks vere of 2 litre capacity. The mixture in flask I. contained the following ingredients:Meat/ 
Meat

Water

Sodium Carbonate (Saturated)

Lactose

Inoculation Mixture
200 grms.

$1000 \mathrm{ccs}$.

$40 \mathrm{ccs}$.

20 grms. $(50 \%)$

$10 \mathrm{ccs}$.

The reaction before incubation was approximately pH.10 The control mixture in flask J. contained the same ingredients as the above with the exception of lactose. The reaction before incubation was approximately pH. 10. Both Ilasks were corked and placed in the incubator at $40^{\circ} \mathrm{C}$ for 8 days, during which time frequent observations were made as to colour, odour and reaction. The following table records the result of these observations:- 
TABLE /5

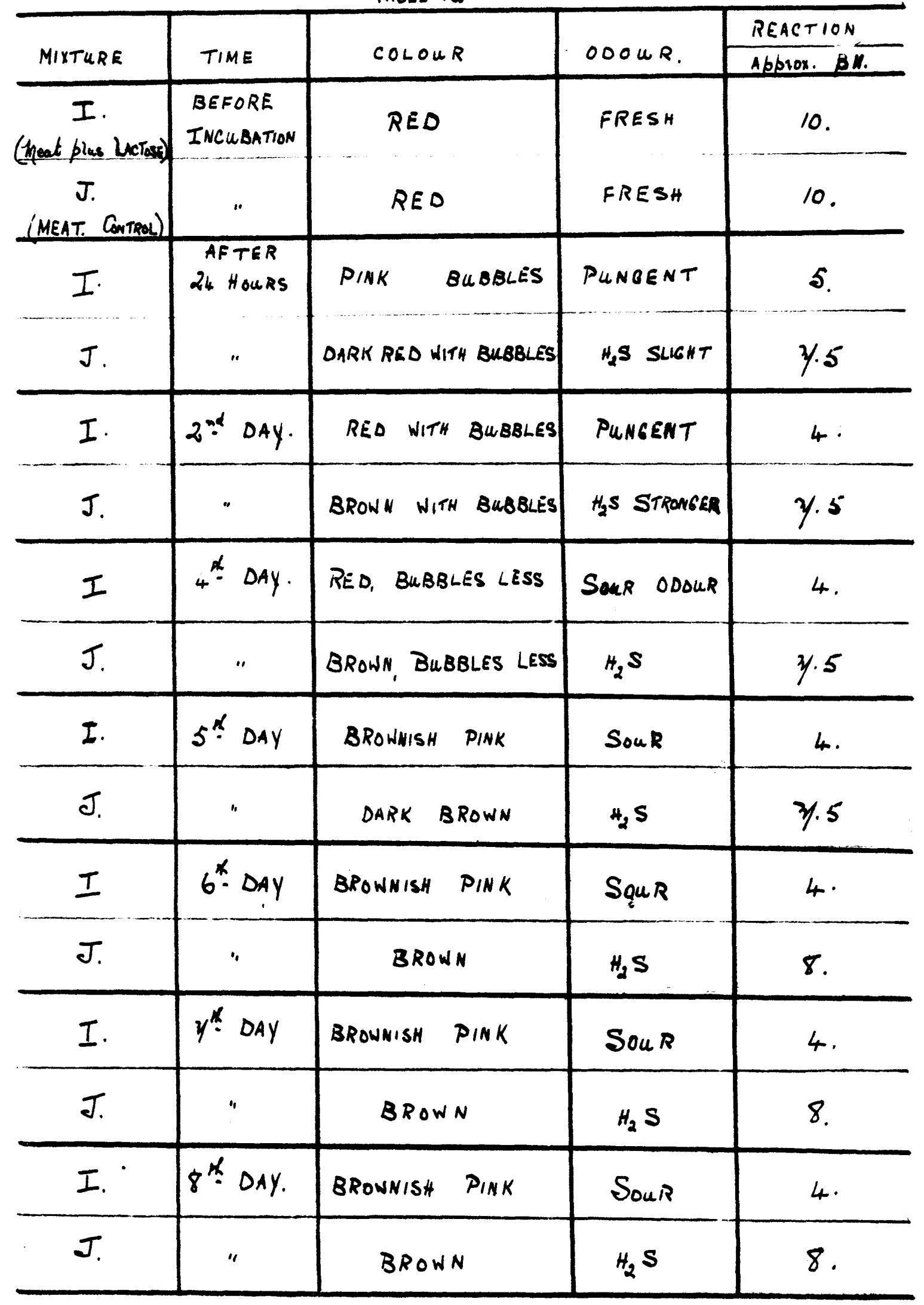


The following observations were made in amplification to the above table.

\section{Mixture. I. (Meat and Iactose)}

Colour. Changed gradually from red to brown.

odour. At no time repulsive.

Bubbles. Iike sour milk throughout. Marked during first 3 days.
Mixture J. (Meat)

Changed rapidly from red to brown.

Repulsive after 2nd day.

After 2nd. day present but less marked than in I.

Reaction. Initial alkalinity ( $\mathrm{pH} .10)$ Initial alkalinity Changed rapidly to acidity (pH.10) Changed $\mathrm{pH}$. 4. remaining thus at gradually to $\mathrm{pH} .8$. 8 th day.

remaining thus at 8 th. day.

Position Fat and meat particles of Solid

floating mostiy on Particles.

Fat and meat particles surface during first three out. mostly at bottom through days, after which time they tended to sink to bottom of flask.

Technique continued:The

The flasks were removed fromincubator. About 5 ccs. of the mixture wese removed from each flask and tested for presence of sugar with Fehling's reagent. The filtrate from I. gave marked reductions with Fehling's reagent indicating residual lactose still present. The filtrate from J. gave no reduction. The contents of both flasks were then subjected to direct distillation. The distillates from each mixture were tested quantitatively for indol by the Colorimetric method and the distillation residue was evaporated to dryness and weighed in each case. Fat was not extracted. The results were as follows:-

\section{TABIS 16.1}

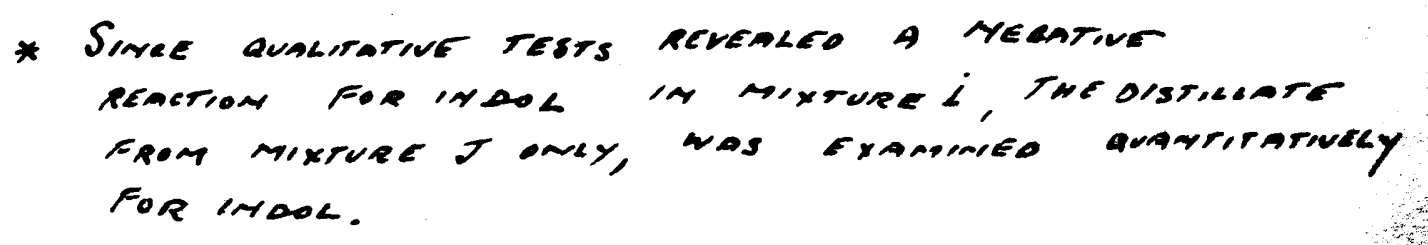


TABIE 16.

\begin{tabular}{c|c|c}
\hline MIXTURE & $\begin{array}{c}\text { INDOI } \\
\text { Grms. }\end{array}$ & $\begin{array}{c}\text { RESIDUE } \\
\text { Grms. }\end{array}$ \\
\hline I. & 0. & 213.83 \\
\hline $\begin{array}{c}\text { J. } \\
\text { (control) }\end{array}$ & 0.03993 & 114.39 \\
\hline
\end{tabular}

Summary of Experiment IV.

In the lactose and meat mixture $I$. no indol was produced after 8 days' incubation at $40^{\circ} \mathrm{C}$. In this mixture, the weight of the residue was much greater than that of the control indicating the absence of any appreclable degree of decomposition.

\section{EXPER IMENT XVI.}

In this experiment mixtures were prepared containing the same ingredients as those in the preceding experiment. The mixtures were placed in flasks designated $K$. and I. respectively, the latter being the control. The same technique was adopted as before. The period of incubation of the mixture was prolonged to 15 days since it was desired to ascertain whether there might be any further changes in the moat and lactose mixture. The results are recorded in the following table:- 
TABLE $1 \%$

\begin{tabular}{|c|c|c|c|c|}
\hline MIXTURE & TIME. & COLOUR & ODOUR & REACTION \\
\hline $\begin{array}{l}\text { (NEAT PIUS LACTOSE) } \\
\text { (MEAT. L CONTROL) }\end{array}$ & $\begin{array}{c}\text { BEFORE } \\
\text { INCUBATION } \\
"\end{array}$ & $\begin{array}{l}\text { RED } \\
\text { RED }\end{array}$ & $\begin{array}{c}\text { FRES H } \\
"\end{array}$ & $\begin{array}{l}10 . \\
10 .\end{array}$ \\
\hline $\begin{array}{l}K \\
L\end{array}$ & $\begin{array}{c}\text { AFTER } \\
24 \text { HOURS } \\
\text { " }\end{array}$ & $\begin{array}{l}\text { PINK WITH BUBBLES } \\
\text { DARK RED WITH BUBBLES }\end{array}$ & $\begin{array}{l}\text { PUNGENT } \\
H_{2} \mathrm{~S} \text { SLIGHT }\end{array}$ & $\begin{array}{c}5 \\
3 / 5\end{array}$ \\
\hline K & $\begin{array}{c}2 \text { nd } D A Y \\
" 1\end{array}$ & $\begin{array}{l}\text { PINK WITH BLBBLES } \\
\text { DARK RED WITH BUBBLES }\end{array}$ & $\begin{array}{l}\text { SouR } \\
H_{2} S\end{array}$ & $\begin{array}{c}4 \\
y \cdot 5\end{array}$ \\
\hline $\begin{array}{l}k \\
L\end{array}$ & $\begin{array}{c}4=\text { DAY } \\
11\end{array}$ & $\begin{array}{cc}\text { PINKISH } & \text { BROWN } \\
\text { BUBBLES SUBSIDING } \\
\text { BROWN WITH } \\
\text { BLBBLES }\end{array}$ & $\begin{array}{l}\text { Sou R } \\
H_{2} \mathrm{~s}\end{array}$ & $\begin{array}{c}4 \\
y \cdot 5\end{array}$ \\
\hline $\begin{array}{l}k \\
L\end{array}$ & $5^{\text {M }}$ DAY & $\begin{array}{c}\text { PINKISH BROWN } \\
\text { BROWN }\end{array}$ & $\begin{array}{l}\operatorname{SOU} R \\
\mathrm{H}_{2} \mathrm{~S}\end{array}$ & $\begin{array}{l}4 \cdot \\
y \cdot 5\end{array}$ \\
\hline $\begin{array}{l}K \\
L\end{array}$ & $\begin{array}{c}6=D A Y \\
=\end{array}$ & $\begin{array}{c}\text { PALE BROWN } \\
\text { BROWN }\end{array}$ & $\begin{array}{l}\text { Sour } \\
\mathrm{H}_{2} \mathrm{~S}\end{array}$ & $\begin{array}{l}4 . \\
y \cdot 5\end{array}$ \\
\hline$k$ & $3 / 1=D A Y$ & PALE BROWN & Sou $R$ & 4. \\
\hline$L$ & " & BROWN & $H_{2} S$ & $y \cdot 5$ \\
\hline$k$ & $8^{*}$ DAY & PALE BROWN & Sou $R$ & 4. \\
\hline$L$ & " & DARK BROWN & $\mathrm{H}_{2} \mathrm{~S}$ & 8. \\
\hline k & $q^{*}=$ DAY & PALE BROWN & Sour & 4. \\
\hline$L$ & $"$ & DARK BROWN & $\mathrm{H}_{2} \mathrm{~S}$ & 8. \\
\hline$k$ & $12^{*}$ DAY & PALE BROWN & Sou $R$ & 4.5 \\
\hline$L$ & $"$ & DARK BROWN & $H_{2} \mathrm{~S}$ & 8. \\
\hline$k$ & $13^{*}=$ DAY & PALE BROWN & SouR & $4 \cdot 5$ \\
\hline$L$ & " & DARK BROWN & $H_{2} \mathrm{~S}$ & 8. \\
\hline$k$ & $14^{*}$ DAY & PALE BROWN & Sou $R$ & $4 \cdot 5$ \\
\hline$L$ & $"$ & DARK BROWN & $\mathrm{H}_{2} \mathrm{~S}$ & 8. \\
\hline$k$ & $15^{*}-D A Y$ & PALE BROWN & Sour & $4 \cdot 5$ \\
\hline$L$ & $"$ & DARK BROWN & $\mathrm{H}_{2} \mathrm{~S}$ & 8 \\
\hline
\end{tabular}




\section{Descriptive Comments on Table 17.}

Changes in colour, odour, position of solid particles, and reaction, similar to those in Experiment $X V$. were observed in both mixtures. One noticeable feature, however, was the change in reaction in the lactose and meat mixture on the twelfth day from $\mathrm{pH}$. 4. to $\mathrm{pH} .4 .5$ at which value it still remained on the eighteenth day.

Technique continued:-

Subsequent distillation of the mixtures revealed the following quantitative results.

TABIE 18.

\begin{tabular}{c|c|l}
\hline MIXTURE & $\begin{array}{l}\text { INDOI } \\
\text { Grms. }\end{array}$ & $\begin{array}{l}\text { RES IDUE } \\
\text { Grms. }\end{array}$ \\
\hline $\mathrm{K} \cdot$ & 0. & 165.71 \\
\hline $\begin{array}{c}\text { I. } \\
(\text { control) }\end{array}$ & 0.04725 & 61.71 \\
\hline
\end{tabular}

Summary of Experiment XVI.

In the lactose and meat mixture $\mathrm{K}$. no indol was produced after 15 days' incubation at $40^{\circ} \mathrm{C}$. In this mixture, the weight of the residue was considerably greater than that of the control. It was, however, less than the weight of the residue of the corresponding mixture in Experiment XY. Indicating a greater degree of decomposition after 15 days' than after 8 days. In the case of the control mixture, a greater yield of indol and a diminution in the weight of residue, compared with the corresponding figures in the control mixtare in Experiment XV., were observed. 


\section{EXPER IMENT XVII.}

The technique in this experiment was the same as in the two prececing experiments. The incubation period was still further prolonged to 27 days. The two mixtures were designated $\mathbf{M}$. and $\mathrm{N}$. respectively, the latter being the control. The results are recorded in the following table:- 
TABLE 19.

\begin{tabular}{|c|c|c|c|c|}
\hline MIXTURE & TIME & COLOUR & $\triangle D O U R$ & $\frac{\text { REACTION }}{\text { ABhYOX. }}$ \\
\hline (MEAT $\stackrel{M}{\text { PLUS LACTOSE) }}$ & $\begin{array}{l}\text { BEFORE } \\
\text { INCUBATION }\end{array}$ & RED & FRESH & 10. \\
\hline (MEAT. CONTROL) & " & RED & $"$ & 10. \\
\hline$M$ & $\begin{array}{l}\text { AFTER } \\
24 \text { HOURS }\end{array}$ & & PUNGENT & $5 \cdot 5$ \\
\hline$N$ & " & DARK RED & $\mathrm{H}_{2} \mathrm{~S}$ SLIGHT & 8. \\
\hline$M$ & $2^{\text {nd }}$ DAY & PINKISH BROWN & Sour & 4 \\
\hline$N$ & 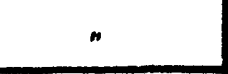 & BROWN & $\mathrm{H}_{2} \mathrm{~S}$ & $y$ \\
\hline$M$ & $4^{*}$ DAY & REDDISH BROWN & SouR & 4 \\
\hline$N$ & $"$ & BROWN & $\mathrm{H}_{2} \mathrm{~S}$ & $y .5$ \\
\hline$M$ & $5^{K}$ DAY & REODISH BROWN & Sow $R$ & 4. \\
\hline$N$ & $"$ & BROWN & $\mathrm{H}_{2} \mathrm{~S}$ & $y \cdot 5$ \\
\hline$M$ & $6^{*}: D A Y$ & PINKISH BROWN & Sou $R$ & 4. \\
\hline$N$ & $"$ & BROWN & $\mathrm{H}_{2} \mathrm{~S}$ & 8. \\
\hline$M$ & 8* DAY & PALE BROWN & Sou $R$ & 4. \\
\hline$N$ & $"$ & DARK BROWN & $\mathrm{H}_{2} \mathrm{~S}$ & 8. \\
\hline$M$ & $12^{*}$ DAY & PALE BROWN & Sour & 4. \\
\hline N & $"$ & DARK BROWN & $H_{2} S$ & 8 \\
\hline$M$ & $15^{x} \cdot D A Y$ & PALE BROWN & $H_{2} S$ FAINT & 5. \\
\hline$N$ & $"$ & DARK BROWN & $\mathrm{H}_{2} \mathrm{~S}$ & 8. \\
\hline$M$ & $16^{*}=$ DAY & PALE BROWN & $\mathrm{H}_{2} \mathrm{~S}$ & 6. \\
\hline$N$ & $"$ & DARK BROWN & $\mathrm{H}_{2} \mathrm{~S}$ & 8. \\
\hline$M$ & $I Y=D A Y$ & PALE BROWN & $\mathrm{H}_{2} \mathrm{~S}$ & 6.5 \\
\hline$N$ & $"$ & DARK BROWN & $H_{2} S$ & 8. \\
\hline M & $20^{K} \cdot D A Y$ & PALE BROWN & $H_{2} \mathrm{~S}$ & $y$. \\
\hline$N$ & " & DARK BROWN & $\begin{array}{l}\mathrm{H}_{2} \mathrm{~S} \text { GETTING } \\
\text { FAINTER }\end{array}$ & 8. \\
\hline$M$ & $21 \div$ DAY & PALE BROWN & $\mathrm{H}_{2} \mathrm{~S}$ & 4.5 \\
\hline$N$ & “ & DARK BROWN & $\mathrm{H}_{2} \mathrm{~S}$ FAINT & 8 \\
\hline$M$ & $22^{\text {nd }}$ DAY & PALE BROWN & $\mathrm{H}_{2} \mathrm{~S}$ STRONG & 8. \\
\hline$N$ & $"$ & DARK BROWN & $\begin{array}{l}H_{2} 5 \text { VERY } \\
\text { FAINT }\end{array}$ & 8. \\
\hline$M$ & $2 y^{x}-O A Y$ & PALE BRONN & $\mathrm{H}_{2} \mathrm{~S}$ & 8. \\
\hline$N$ & $"$ & DARK BROWN & $H_{2} s$ & 8. \\
\hline
\end{tabular}


Descriptive Comments on Table 19.

Changes in colour, odour, position of solid particles, and reaction, similar to those in the two preceding experiments were observed until the 15 th day of incubation when a change in the reaction of the meat and lactose mixture from $\mathrm{pH}$. 4. to $\mathrm{pH}$. 5. took place. On this day, also, a faint odour of $\mathrm{H}_{2} \mathrm{~S}$ was perceptible. The reaction of this mixture was found to become progressively less acid until it recorded a value of approximately pH. 8. on the 22 nd. day. Coincident with this change in reaction the odour of $\mathrm{H}_{2} \mathrm{~S}$ became more marked.

Technique continued:-

Subsequent direct distillation of the mixtures revealed the following quantitative results.

TABIE 20.

\begin{tabular}{c|l|l}
\hline MIXTURS & $\begin{array}{c}\text { INDOI } \\
\text { Grms }\end{array}$ & $\begin{array}{c}\text { RESIDUE } \\
\text { Grms. }\end{array}$ \\
\hline M. & 0.02128 & 62.61 \\
\hline $\begin{array}{c}\text { N. } \\
\text { (control) }\end{array}$ & 0.048125 & 43.79 \\
\hline
\end{tabular}

Summary of Experiment XVII.

In the lactose and meat mixture $M .0 .02128$ grms. of indol were recovered after 27 days' incubation at $40^{\circ} \mathrm{C}$. Since the reaction of this mixture became definitely alkaline on the twentieth day it is likely (on the basis of Experiment II.) that this amount of indol represented the quantity which had been formed between the twentieth and/ 
and the twenty-seventh day. The amount produced during that time was less than that of the control. The weight of the residue in the lactose and meat mixture was greater than that of the control but less than the weight of the residue of the corresponding mixture in Experiment XVI. indicating a still greater degree of decomposition after 27 days than after 15 days. In the case of the control mixture, while the yield of indol was not much greater, the weight of the residue was less than the corresponding figures in the control mixture in Experiment XVI.

\section{EXPERTMENT XVIII.}

In this experiment the incubation period of the mixtures was prolonged to 47 days in order to ascertain whether the yield of indol from the meat and lactose mixture eventurlly equalised that of the control. The two mixtures were designated 0 . and $P$. respectively, $P$. being the control. The results are recorded in the following table:- 
TABLE 21.

\begin{tabular}{|c|c|c|c|c|}
\hline & & & & REACTION \\
\hline MIXTURE & TIME & COLOUR & $0004 R$ & Abbrax. P.H. \\
\hline $\begin{array}{c}0 \\
\text { LMEAI PlUS LACTOSE) }\end{array}$ & $\begin{array}{l}\text { BEFORE } \\
\text { INCUBATION }\end{array}$ & & FRESH & 10. \\
\hline MEAT ${ }^{P}$ CONTROL & 1 & RED & 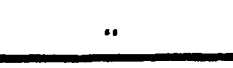 & 10. \\
\hline 0 & I\$ DAY & PINK WITH BUBBLES & PUNGENT & s. \\
\hline$P$ & " & DARK RED WITH BUBBLES & $H_{2} S \quad S W G H T$ & $y \cdot 5$ \\
\hline 0 & 2: DAY & $\begin{array}{l}\text { PINKISH RED WITH } \\
\text { BUBBLES }\end{array}$ & SOUR & 4. \\
\hline$P$ & $“$ & $\begin{array}{c}\text { REDDISH BROWN WITH } \\
\text { BUBBLES }\end{array}$ & $\mathrm{H}_{2} \mathrm{~S}$ & 8. \\
\hline & $4^{K}$ DAY & PINKISH RED WITH & SouR & 4. \\
\hline$P$ & ". & $\begin{array}{c}\text { REDDISH BROWN WITH } \\
\text { BLBBLES }\end{array}$ & $H_{2} \mathrm{~S}$ & 8. \\
\hline 0 & $y^{\prime \prime}=D A Y$ & & SouR & 4 . \\
\hline$P$ & " & BROWN & $\mathrm{H}_{2} \mathrm{~S}$ & 8. \\
\hline 0 & Q: DAY & $P / N R$ & FAINT $H_{d} s$ & 4 \\
\hline$P$ & $"$ & DARK BROWN & $H_{2} S$ & 8. \\
\hline & $12^{x}=D A Y$ & PINKISH BROWN & FAINT $H_{2} S$ & 4. \\
\hline$P$ & ". & DARK BROWN & $H_{2} \mathrm{~S}$ & 8. \\
\hline 0 & $13^{2}=D A Y$ & PALE BROWN & FAINT $\mathrm{H}_{2} \mathrm{~S}$ & $4 \cdot 5$ \\
\hline$P$ & 4 & DARK BROWN & $H_{2} \mathrm{~S}$ & 8. \\
\hline 0 & $15^{\prime \prime}$ DAY & PALE BROWN & $\mathrm{H}_{2} \mathrm{~S}$ & 5 \\
\hline$P$ & " & DARK BROWN & $H_{2} S$ & 8 \\
\hline 0 & $16^{x}=\Delta A Y$ & PALE BROWN & $\mathrm{H}_{2} \mathrm{~S}$ & 5.5 \\
\hline$P$ & " & DARK BROWN & $\mathrm{H}_{2} \mathrm{~S}$ & 8. \\
\hline 0 & $19^{x}$ DAY & PALE BROWN & $\mathrm{H}_{2} \mathrm{~S}$ & $5.5^{\circ}$ \\
\hline$P$ & $"$ & DARK BROWN & $H_{2} S$ & 8. \\
\hline 0 & $20: D A Y$ & PALE BRONN & $\mathrm{H}_{2} \mathrm{~s}$ & 6. \\
\hline $\boldsymbol{P}$ & • & DARK BROWN & $H_{2} S$ & 8. \\
\hline 0 & $22^{-1}$ DAY & PALE BROWN & $H_{2} S$ & $6 \cdot 5$ \\
\hline$P$ & 4 & DARK BROWN & Hes & 8. \\
\hline 0 & $26^{\prime \prime}$ DAY & PALE BRONN & $\mathrm{H}_{2} \mathrm{~S}$ & $y$. \\
\hline$P$ & " & DARK BROWN & $\mathrm{H}_{2} \mathrm{~S}$ FAINT & 8 \\
\hline 0 & $2 y^{\prime \prime} D A Y$ & PALE BROWN & $H_{2} s$ & 4.5 \\
\hline$\rho$ & “" & DARK BROWN & $H_{2} S F A I N T$ & 8 \\
\hline 0 & $28^{\prime \prime}$ DAY & PALE BROWN & $\mathrm{H}_{2} \mathrm{~S}$ & 8. \\
\hline$p$ & " & DARK BROWN & $\mathrm{H}_{2} \mathrm{~S}$ & 8 \\
\hline 0 & $33^{-9} \cdot D A Y$ & BROWN & $\mathrm{H}_{2} \mathrm{~S}$ & 8. \\
\hline$P$ & “ & BROWN & \#S & 8 \\
\hline 0 & 364 DAY & BROWN & $H_{2} S$ & 8. \\
\hline $\boldsymbol{P}$ & $\because$ & BRown & $H_{2} S$ & 8. \\
\hline 0 & $4 y^{\prime \prime} \cdot \Delta A Y$ & BRONN & $\mathrm{H}_{2} \mathrm{~S}$ & 8. \\
\hline$P$ & 11 & BROWN & 45 & $8 \cdot$ \\
\hline
\end{tabular}


Descriptive Comments on Table 21.

Changes in colour, odour, position of solid particles, and reaction, similar to those in the preceding experiments were observed until the 13th day of incubation when a change in the reaction of the meat and lactose mixture from $\mathrm{pH}$. 4. to $\mathrm{pH} .4 .5$ took place. A faint odour of $\mathrm{H}_{2} \mathrm{~S}$ was perceptible on the 9 th day. The reaction of this mixture was then found to become progressively less acid thereafter until it recorded a value of approximately pH. 8. on the 28th day. Coincident with these changes in reaction the odour of $\mathrm{H}_{2} \mathrm{~S}$ became more marked.

Technique continued:-

Subsequent direct distillation of the mixture rovealod the following quantitative results:-

TABIE 22 .

\begin{tabular}{|c|l|l|}
\hline MIXIURE & $\begin{array}{c}\text { IND OI } \\
\text { Grms. }\end{array}$ & $\begin{array}{c}\text { RFSIDUE } \\
\text { Grms. }\end{array}$ \\
\hline 0. & 0.07832 & 63.33 \\
\hline $\begin{array}{c}\text { P.irol) } \\
\text { (control }\end{array}$ & 0.07698 & 50.63 \\
\hline
\end{tabular}

\section{Summary of Experiment XVIII.}

In the lactose and meat mixture 0.0 .07832 grms. of indol were reoovered after 47 days' incubation at $40^{\circ} \mathrm{C}$ an amount actually greater than that produced in the control Since the reaction of this mixture became definitely alkaline on the 26 th day it is likely (on the basis of Experiment II.) that this amount of indol represented the quantity which had been formed between the trenty-sixth and/ 
and the forty-seventh days. In the case of both mixtures the yields of indol were greater than those from the corresponding mixtures in the preceding experiments. The weights of the residues however were not consistently diminished.

The results of Experiments XV., XVI., XVII., and XVIII. are summarised in the following table:-

TABIE 23.

\begin{tabular}{|c|c|c|c|}
\hline \multirow{4}{*}{$\begin{array}{c}\text { Meat \& lactose } \\
(50,0)\end{array}$} & $\begin{array}{c}\text { INCUBATION } \\
\text { Days }\end{array}$ & $\begin{array}{c}\text { INDOI } \\
\text { Grms. }\end{array}$ & $\begin{array}{c}\text { RES IDUE } \\
\text { Grms }\end{array}$ \\
\cline { 2 - 4 } & 8 & 0. & 213.83 \\
\cline { 2 - 4 } & 15 & 0. & 165.71 \\
\cline { 2 - 4 } & 27 & 0.02128 & 62.61 \\
\cline { 2 - 4 } Meat (Control) & 47 & 0.07832 & 63.33 \\
\cline { 2 - 4 } & 8 & 0.03995 & 114.39 \\
\cline { 2 - 4 } & 15 & 0.04725 & 61.71 \\
\cline { 2 - 4 } & 27 & 0.048125 & 43.79 \\
\cline { 2 - 4 } & 47 & 0.076985 & 50.63 \\
\hline
\end{tabular}

Summary of Experiments XV. - XVIII.

In the lactose and meat mixtures and in the controls, changes in colour, odour and reaction were ovident after 24 hours. These changes commenced apparently simultaneoualy The rate of change as evidenced by predominance of gas bubbles and approximate pH. value was apparently greater 
in the lactose and meat mixture than in the control within the first 24 hours. In the case of the lactose and meat mixtures, the delay in development of the dark brown colour was striking, and the acid phase was prolonged, occupying the entire period of incubation in Experiments XV. and IVI. 8 and 15 days respectively, and the greater part of the period of incubation in Experiments XVII. and XVIII., 20 and 26 days respectively.

The duration of the inhibitory influence of lactose on indol production at $40^{\circ} \mathrm{C}$ was not more than 27 days. The extent of this inhibitory influence was represented by the production of only 0.02128 grms. of indol in a meat and lactose mixture after 27 days incubation compared with a production of 0.048125 grms. in a meat mixture over the same period. When incubation was continued for a period of 47 days the indol production of the sugar and meat mixture was even in excess of that in the control, indicating that subsequent to the termination of the period of sugar inhibition the extent of indol production is relatively increased compared with the control mixtures. The amount of distillation residue in sugar and meat mixtures incubated for more than 27 days also indicates a greater rate of decomposition.

\section{Discussion of Results in Experiments II.. - XVIII.}

The putrefaction of ox-flesh in the presence of proportionate amounts of certain sagars especially lactose and glucose is associated with definite changes in colour. odourl 
odour, and reaction, distinct from those observed when no sugar is present.

The time of occurrence of indol in the course of putrefaction in the presence of sugar, is delayed compared with its time of occurrence when no suzar is present. When indol, thus delajed, does appear its occurrence is associfued with the development of an alkaline reaction together with changes in colour and odour, similar to those previously observed when no sugar is present. The amount of Indol subsequently produced is increased compared with thet produced in a control mixture containing no sugar. The eseential influence of lactose, and glucose, therefore, is to delay and not to prevent the onset of the brown colour, the odour of sulphuretted hydrogen, the alkaline reaction, and the production of. indol in the course of putrefaction. The eventual intensity of these changes thus delayed by sugars, is apparently increased under the experimental conditions described.

From these observations it may be deduced that when sugar is added to mixtures of meat and water of similar composition and infected from the alr, definite galltative and quantitative ohanges take place, which alfer in the different mixtures accoraing to the type and the amount of sugàr uset.

Under the experimental conditions described, the qualltatfo quantitative changes in the putrefaction of meat mixtures, infected from the air, would seem to depent primarily upon the composition of the medium. 
From the precedine observations it is seen that the presence of the sugars lactose and glucose in meat mixtures is associated with a striking temporary diversion of the line of chanes characteristic of putrefaction. During this phase of temporary diversion the usual indications of complete amino-acid cleavage, such as indol and phenol, are abrontialthough the changes otherwise, such as gas formation and sour odour, are not characteristic of the absence of bacterial activity.

The influence of sugar in delaying indol production, therefore, suggests a diversion rather than an arrest of bacterial activity. From the clinical standpoint, temporary diversion of bacterial activity of sugar from potentially toxic protein soil might offer an altemative therapeutic principle to that of arrest of bacterial activity by germicidal substances. The clinical applicability, however, of any such principle, would depend primarily upon the conception held, concerning putrefactiot in so far as this process may be a menace to the health of man.

The essential function of putrefaction in the econos of nature is undoubted. Its universality would almost justify the conception of an omipresent putrefactive organismal force, perceptibly manifest by changes after death of protoplasm. It would seem that bacterial activity is inseparably associated with an initial medium of dead organic matter. It is obviously of advantage that dead matter should be decomposed rather than that it should be left undecomposed. In this connection Pasteur's words, already quoted in Section $I$. concerning the functe of microorganisms in preventing the encumberance of living matter, are noteworthy. Dixon (1) referring to the 
beneficent functions of putrefactive bacteria has pointed out that choline normally produced by the pancreatic digestion of lecithin might well induce harmful effects if absorbed from the bowel in quantity, were it not broken up by bacterial enzymes into carbon dioxide, marsh gas and ammonia, thus protecting the organism. Under what conditions then, may putrefaction within the intestine be regarded as a potential source of disease? No principle involving either the arrest or the diversion of intestinal putrefaction can find a rational application until this question has been answered. The remainder of this thesis represents an attempt to answer this question. 


\section{BIBIIOGRAPHY: (SECTION II.C.)}

(I) DIXON, W6: 'A Discussion on Alimentary Toxaemia;

Its sources, consequences, and treatment.'

Proceedings of the Royal Society of Medicine.

1913, Vi, part i, 129. Iond on: Longmans,

Green \& CO. 


\section{SECTION III.}

\section{OBSERVATIONS ON INTESTINAL FUNCTION.}

\section{A. PREVIOUS WORK INCLUDING SPECIAL REVIEWS OF THE WORK OF CORLETTE AND CATHCART AND LEATHES.}

When approached in the light of the foregoing observations, the subject of putrefaction within the intestine, invites certain consideration.

In both sites, the interior of the glass flask on the one hand and the lumen of the living intestine on the other, the conception of putrefaction is primarily that of a protein-containing medium in which changes, physical, chemical, and bacteriological, are taking place. In the case of the putrefactive contents of the glass flask, these changes are detectable by direct methods. The interaction of the glass flask with its contents is negligible. In the case of the putrefactive contents of the hollow viscus, of which the natural attributes are secretion, movement, and absorption, these changes are not detectable by direct methods under ordinary circumstances. The interaction of the living intestine with its contents, in terms of secretion, of movement, and of absorption, demands first consideration.

SECRETION

Information concerming intestinal secretion has been obtained chiefly from fistulae in man and from experiments on animals.

In 1858, Busch (1), made direct observations concerning the effect of various stimuli upon intestinal secretion in the case of a women with a fistula in the upper part of the small intestine. His finding was that thel 
the flow of secretion was dependent upon mechanical and other stimuli, in the absence of which no secretion occurred.

In 1864, Thiry (2), devised a method of isolating a loop of small intestine and of establishing a fistula between the isolated portion and the abdominal wall through which secretory function could be observed in fasting dogs.

A few years later, Moreau (3) found that profuse secretion followed division of the nerve supply in the experimental loop of bowel. Moreau also was the first to inject magnesium sulphate into a loop of intestine and found that a resultant increase in secretion was produced within the particular loop. These findings were confirmed by Lauder Brunton and Pye-Smith (4) in 1874.

In 1879, Demant (5) studied intestinal secretion in the case of a man with a fistula in the lower part of the small intestine. He noted the increase in secretion which followed ingestion of food.

Vella (6), In 1881, modified Thiry's original technique for experimental fistulae in dogs. He made two fistulous apertures, one in front of the other of which one communicated with the proximal and the other with the distal portion of the isolated intestinal tube.

All these investigations were concerned with the effeots of various stimuli, mechanical, chemical, electrical, and dietetic, upon intestinal secretion from the small intestine.

Very little work has been done on secretion from the large intestine. In 1875 Marckwald (7) found that the secretion of the colon possessed neither diastatic nor proteolytic power in a case of praeternatural anus communicating with the caecum. According to Starling (8) investigations by the fistula method have show that secretion from the / 
the large intestine is scanty and composed almost wholly of mucus. Watery secretion, however, is produced on mechanical stimulation.

As an example of changes taking place in a medium within the lumen of the intestine the work, of Corlette (9) in 1900 is of particular interest since he made observations as to colour, consistence, odour, reaction, weight, and nitrogen values of the accumulated secretory contents in a segment of intestine over given periods. A special review of corlette's experiments has therefore been made.

\section{REVIEW OF CORIETTE'S EXPERIMENTS UPON INTESTINAL SECRETION.}

Corlette analysed the contents within an exclusion segment of ileum in the cases of five dogs each of which had been fed on special diets for varying periods.

While Halstead (10) had originally performed this operation in 1887, Hermann (11) was the first to perform it in 1889 for the special purpose of studying intestinal secretion and excretion.

The following is Corlette's desoription of his technique:"At the operation upon each animal, the caceum was located "and the ileum measured upwards to a point $18 \mathrm{~cm}$. abore its "function. with the caecum and then again to a second $36 \mathrm{~cm}$. "further up. The bowel was cut across at each point and the "36 cm. long segment was syringed through from end to end "until a colourless efferent was obtained. The segment after "being closed at each end with silk sutures was returned to "the abdominal carity. The proximal and distal ends of the "main channel were then approximated and the abdomen was nclosed. The animals were then starved and subsequently "had milk diet for some days after the operation before 
"commencing the special diet. Two of the animals received "a pure meat diet intended to produce a high nitrogen equil"ibrium and relatively low in calories. The other three "animals received a predominantly carbohydrate diet consist"ing of oatmeal sugar and milk producing a relatively low "nitrogen equilibrium but of a high caloric value. One of "the latter dogs developed 'canine influenza' and refused nfood so that its condition became one of fasting and acute "specific disease. After varying periods on these diets "the animals were killed by chloroform. The loop of bowel "was removed in each case and the contents were examined." I have extracted some of the salient figures from Corlette's results and I have represented the weights of secretion, moist and dry, in graphic form with other quantitative and qualitative details pertaining to each secretion analysis, superimposed in tabulated form. For the purpose of this thesis I have adopted this mothod of reviewing Corlette's findings since it would seem to furnish, at a glance, both a qualitative and quantitative conception of changes in an organic medium which were found to have taken place within the lumen of a closed loop of living bowel exercising, as far as could be ascertained, its inherent function of secretion and possibly of absorption although denied by operative procedure, of its translatory peristalsis. In his original article, Corlette gives his figures in table form only. I have calculated the nitrogen values, which he represents in percentage, in terms of total $N$. and $N$. per grm. The following diagram, in graph and table form, represents Corlette's findings on intestinal secretion:-

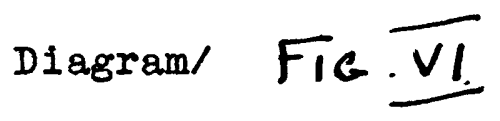


Fig. VI Corlette's findings on intestinal secretion.

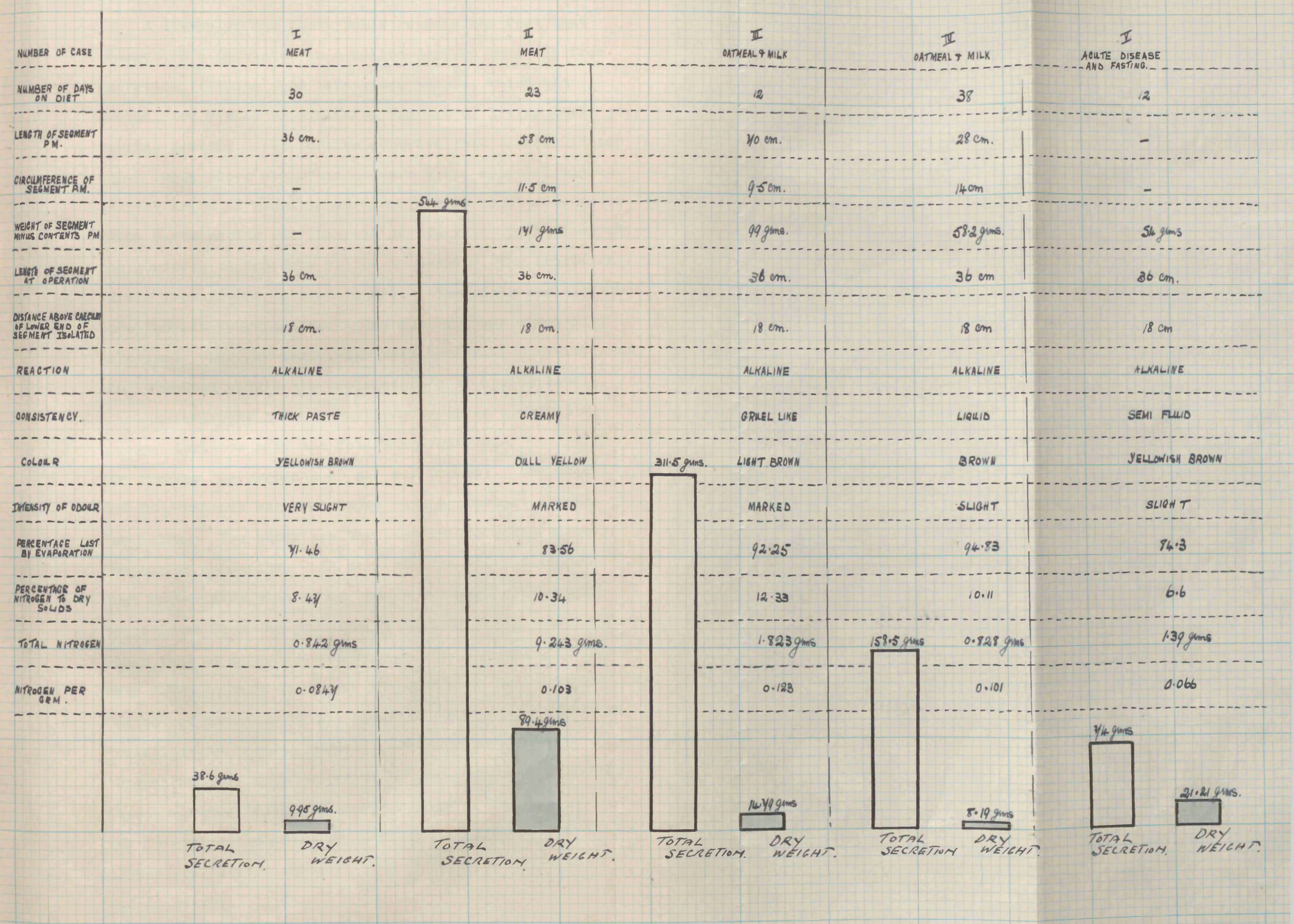


A survey of the above table reveals the fact that changes were initiated in a medium derived entirely from secretion, arising from intestinal mucosa, which had accumulated within an exclusion segment of living bowel over varying periods. It must be conceded that the conditions under which those observations were made, epproach almost as near as it is possible so to do, those conditions under which putrefaction was observed in flasks. The colour of the contents varied from yellow to brown. The consistence varied from liquid to semi-liquid. The odour was distinetive but not putrefactive. The reaction was constantly alkaline. Changes associated with bacterial activity were thus observed within the excluded loop of living bowel.

In reviewing his observations on those qualitative changes Corlette adds the following remarks:"On opening the segments no gas was present. The colour "of the contents was associated with a constant absence of "urobilin. The odour was the same in all cases although "varying in intesnity. It was not like that of faeces "but rather like that of a stale puralent sputum more "associated with the presence of various fatty acids rather "than that of aromatic compounds. The intensity of odour "was found to vary in direct proportion to the amount of ary "weight of material in the contents indicating a possible "relationship between bacteria and increased amount. norganisms have been suspected by other writers as having "a stimulating effect upon secretions." The foregoing statement is of interest in the light of comparison between changes found in organic media in vivo and in vitro. 
The most striking feature in Corlette's results is the marked aifference in the weight of intestinal contents between dogs I. and II. although both animals were on the same diet. In this connection, Corlette emphasises the fact that since the segments were completely closed during the periods of diet, the accumulation of contents was entirely due to the secretory power of the intestinal mucous membrane. He indicates further that the difference in weight between I. and II. lay in a difference in respective secretory power. Difference in weight in intestinal contents of dogs III. IV., and V. were also evident although these animals were all on the same diet.

Another feature of his results is the comparatively slight difference in the percentage of water and of nitrogen in each case, in spite of the wide difference in weight. The greatest nitrogen value was found in III. $(12.33 \%)$ and the smallest in I. $(8.47 \%)$. III represented an accumulation of 12 days and $I$. of 30 days. The highest percentage of water lost in evaporation was also found in III.(92.25\%) and the lowest water percentage in I. (71.46). A comparative consistency in composition as regards water and nitrogen was thus evident although the amount of secretion produced was seen to vary within comparatively wide limits. Since the diet was the same in I. and II. Corlette concluded that differences of metabolism caused by diet had no influence on the amount or constitution of contents accumulating in an excluded segment of ileum. Furthermore, in view of the high nitrogen value in III. he concluded that this nitrogen mut have existed originally as a constituent of a much more highly nitrogenised compound than protein since in this experiment total fats amounted to $59.37 \%$ and ash to $6.84 \%$ making a total of $66.21 \%$ and 
a remaining $33.79 \%$ which if it were in protein would present $\frac{33.79}{6.25}-5.42 \%$ of $N$. The actual percentage of N. was, however, more than double this $12.33 \%$, enough to yield 77.06 protein. He concluded that the only source of this highly nitrogenous compound could be found in the secretion from the intestinal wall or in the bodies of bacteria. On the basis of his results, he also sugrested that if the symptoms in intestinal obstruction were largely due to the development of toxic substances by bacteria in accumulated bowel contents undergoing stasis, their development must depend on some factor additional to what existed in these exclusion experiments since none of the dogs experimented upon exhibited such symptoms.

Corlette's exclusion segment of bowel represented a hollow viscus into which no food was introduced and in which peristaltic movement at least of a translatory character could be discounted. From the clinical standpoint, the conception to be gathered from his work would seem to be that the lumen of the eut is a place into which substances, not derived from food and more highly nitrogenised than proteins, may be introduced apparently through intestinal secretions or organisms or both and that variation in the amount of these substances can exist independent of direct contact of food material with the lumen of the bowel and independent of peristaltic morement.

$\Delta$ conception of secretion, apart from morement and absorption, is thereby obtained. Morement, at any rate, was not an active factor in those experiments. As far as absorption is concerned, while no estimations were made in this connection, Corlette's observations concerning the absence of any clinieal evidence of toxaemia are suggestive/ 
suggestive of a possible interference in absorptive functions under the conditions of his experiments.

\section{ABSORPTION.}

Information concerning intestinal absorption has been obtained, like that conceming secretion, from observations in certain pathological conditions in man and from experiments on animals. The problem of absorption at once introduces a study of the essential influence of the vital funotions of the bowel upon its contents. No attempt is here made to review the literature on the subject, but rather to quote certain experiments which may have a bearing upon intestinal putrefaction.

In 1869, Bauer (12) observed the influence of the rectal injection of albuminous substances in dogs which had been starved until the daily excretion of urea had become constant. He found that the amount of urea was increased after these injections and concluded that absorption of albumen had taken place. In 1871, Eichhorst (13) found that the large intestine was capable of absorbing albumoses and peptones, Ilebig's extract of beef, egE albumin mixed with salt; and solutions of gelatin, but that it was uable to absorb pure white of ege and serum albumen. 1 year later Ieube (14), made some observations in a case of praeternatural anus in the left inguinal region commanicating with the sigmold flexure, on the basis of which he estimated that the whole human large intestine could only absorb 6 grms. of albumin in 24 hours. Furthermore he stated that every faotor which caused irritation of the gat hindered absorption. His results were confirmed by czerny and Latschenberger (15) working on the same case in 1874. An interesting point in connection with this case was that the rectam only, could 
be filled with the nutritive fluids. In 1875 Marckwald

found in his case of praetermatural anus, already quoted, that the whole large intestine was capable of absorbing 250 grms. of water in the course of 12 hours.

Information is sought, however, chiefly as to the conditions under which absorption occurs in relationship to secretion and to movement. In this connection, a more intimate conception of the process of intestinal absorption, in so far as it may be related to secretion and movement, is furmished by the work of Cathcart and Leathes (17) who, in 1906, investigated the absorption of proteins from the intestine. A special review of the work of Cathcart and Ieathes has therefore been made.

REVIEN OF THE EXPER IMENTS OF CATHCART \& IFATHES ON INTESTINAL ABSORPTION.

Cathcart and Ieathes carried out a series of experiments upon dogs on similar lines to those which had been done by Salvioli (18) in Iudwig's laboratory in 1880. As a result of the first six experiments in this series in which peptone was introduced into the lumen of an isolated length of dog's bowel perfused with undiluted dog's blood, cathoart and Leathes arrived at the following conclusions:-

1. Perfusion of the isolated bowel of dogs even with undiluted dog's blood does not keep the mucous membrane in a normal condition although to judge by the movements executed, it keeps the muscular coats alive.

2. No demonstrable absorption of nitrogenous substances takes place under these conditions.

3. Peptone is hydrolised in the perfused bowel and apparently this is the fate too of some of the proteids of the effused blood since the nitrogen in uncoagulable combin- 
combinations in the bowel, increased in amount during the course of the experiments.

Since the qualitative and quantitative findings in the intestinal contents in these experiments are of interest, the figures obtained by Cathcart and Leathes in two of the experiments are quoted below.

"EXPERIMENT A. Solution introduced into Iumen of bowel.

"Witte's peptone 10\% - $160 \mathrm{ccs}$.

"Total nitrogen content - $1616 \mathrm{ccs}$. - I0 $\mathrm{IH}_{3}$.

n(Introduced in six portions at intervals of $\frac{1}{4}$ hour.)

"Fluid recovered. From lumen of bowel after two hours' per-

"fusion and $\frac{1}{2}$ hour after last portion of nutritive solution

"had been added.

$n$ Colour. Dark (Stained with blood)

$n$ Consistence. Thick and pasty.

$"$ Quantity. $285 \mathrm{ccs}$.

$n$ Nitrogen (of filtrate after coagulation by heat)

n $1810 \mathrm{cc} . \mathrm{IO} \mathrm{NH}_{3}$.

"EXPERIMENT B. Solution introduced into lumen of bowel.

"Filtrate pancreatic aigest

150 es.

notal nitrogen content $360 \mathrm{cc} . \stackrel{\mathrm{N}}{\mathrm{I} O} \mathrm{NH}_{3}$. n (Introduced as above)

"Fluid recovered. (Similar conditions to above)

$$
\begin{aligned}
& n \\
& n \\
& n
\end{aligned}
$$$$
\text { n }
$$

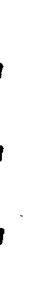

Consistence. Thick and pasty

Quantity.

Nitrogen (or filtrate after coafulation by heat) 590 cc. $\frac{\pi}{10} \mathrm{NH}_{3} \cdot "$

The conditions of those two experiments on the dog, although modified by various surgical measures, approach one stage nearer the conditions which are likely to exist in/ 
in man. Nutritive fluid of known composition is added to the upper end of the open loop of living bowel. After a given time fluid is collected from the lower end of the loop of living bowel and from the analysis of this fluid information is derived as to absorption. Cathcart and Leathes were dissatisfied with their results which were negative as regards absorption from the intestine. Nevertheless their findings provide certain data of interest to the present thesis. The very fact that their evidence pointed to the absence of absorption, while peristalsis was obviously present, as evidenced by visible movements, is of value, since it indicates a possible independent relationship between absorption and peristalsis.

Cathcart and Leathes, then proceeded with another series of experiments in which they inserted a vertical tube into either end of a length of dog's intestine which had been divided at the beginning of the jejunun and the end of the ileum. Nutritive fluids for absorption were introduced by the upper tube and the fluidsexpelled by peristalsis from the lumen of this portion of intestine were collected through the lower tube. In most cases catheters were introduced into the ureters through which the urine was collected and measured. Before this operation the dogs had been adequately prepared by 36 hours starvation during which time 1 arachm of Iiq. ext. felix mas and castor ofl had been administered at an interval of six hours. After the operation, the abdominal wound was closed allowing only the tubes leading from the intestines or ureters to project between the sutures. The fluids introduced and recorered from the intestines were analysed. Samples of blood dram from the carotid before the administration of the nutritive fluid and at the end of the experiment were also analysed. 
As in the case of Corlette's work, I have represented, for the purpose of this thesis, the figures obtained by Cathcart and Leathes, pertainine to the quantity of fluid introduced and recovered from the bowel, in graphic form with other quantitative details superimposed in tabulated form. In their original article cathcart and Leathes record their findings in table form only. I have again adopted the above method for the reasons already stated in my review of Corlette's work. In this instance, the method would seem to furnish a conception more of the quantitative changes in an organic medium which were found to have taken place within the lumen of an open loop of living bowel, exercising, as far as could be ascertained, its inherent functions of secretion, movement and absorption. The following diagram, $A$ in gil and table form, represents the findings of Cathcart and Jeathes on intestinal absorption:-

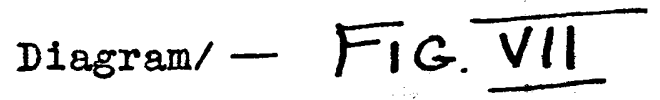


I have calculated the figures pertaining to the fluid retained in the loop of bowel in order to show the possible relationship between absorption and retention.

\begin{tabular}{|c|c|c|}
\hline EXPER IIEENT & $\begin{array}{c}\text { FIUID RETAINLD } \\
\text { ces }\end{array}$ & $\begin{array}{l}\text { NITROGIIN ABSORBED } \\
\text { cc. } \frac{\pi}{10} \mathrm{NH}_{3} .\end{array}$ \\
\hline 1. & 133 & 365 \\
\hline 2 & 105 & 551 \\
\hline 3 & & 240 \\
\hline 4 & 42 & 492 \\
\hline 5. & 80 & 295 \\
\hline 6. & 94 & 714 \\
\hline 7. & 100 & 464 \\
\hline 8. & 115 & 432 \\
\hline 9. & 185 & 692 \\
\hline 10. & 230 & 460 \\
\hline 11. & 149 & 223 \\
\hline 12. & 170 & 725 \\
\hline 13. & 180 & 0 \\
\hline
\end{tabular}

In reviewing their results these investigators made the following observations:-

(1) The amount of nitrogen absorbed in the course of from two to three hours, correspondedto an amount of proteid that varied from about 2 to $6.5 \mathrm{grms}$.

(2) The total nitrogen in a given volume of blood, in every case, was diminished, in part at any rate, on account of the water absorbed from the intestine.

(3) The amount of nitrogen present in the form of compounds that are not precipitated by tannic acid was increased. Their conclusion therefore was that during the absorption of nitrogenous substances, whether pure albumoses, Witte's 
-peptone or digestion products that do not give the buiret reaction, the nitrogenous substances in the blood are not precipitated by tannic acid are definitely increased in amount, though only to a small extent.

From the standpoint of the present thesis, a survey of the above graphic and tabulated results reveals a definite diminution in the amount of fluid recovered compared with the amount introduced in all the experiments with the exception of $\mathrm{N} 0.3$ where the fluid recovered was actually in excess of that introduced. The amount of the fluid recovered from the lower end of the experimental loop after a period varying from two hours to three hours, ten minutes may be taken to represent actual secretion from the bowel or nutritive fluid which escaped absorption or a combination of both. The aifference between the amount of fluid introduced and the amount of fluid recovered represents the amount of fluid retained. When this latter figure is compared with the amount of nitrogen absorbed in each case (as in above table) an interesting relationship is revealed. In Experiment 6, for example, where the amount of fluid retained $(94 \mathrm{ccs}$.$) is less than that retained either in$ Experiments $1,2,7,8,9,10, \& 11$, the amount of nitrogen absorbed $\left(714 \mathrm{cc} . \mathrm{NO}_{\mathrm{N}^{\circ}}\right)$ is actually greater than that absorbed in any of those experiments. Furthermore, in Experiment 3 . where in fact the amount of fluid recovered is greater than that introduced, the figures show that a definite amount of nitrogen has been absorbed ( $240 \mathrm{cc}$ $\mathrm{N} \mathrm{NH}_{3} \cdot$ ) . The amount absorbed in this case is actually greater than absorbed, for example, in Experiment 11, where the fluid retained is $149 \mathrm{ccs}$. The increase in the amoutt of fluid recovered in this instance is presumably due to secretion. 
The conclusions then which are suggested by my interpretation of the results obtained by Cathcart and Leathes are:-

(1) That a greater retention of fluid within the lumen of the bowel does not necessarily indicate a greater absorption from the bowel.

(2) That a greater expulsion of fluid from the bowel does not necessarily indicate a lesser absorption from the bowel.

A conception of absorption associated with movement is thereby obtained. The fluid recovered from the isolated loop of intestine was expelled by peristalsis; Its amount, therefore, was an indication of movement as well as of secretion or of unabsorbed nutritive fluid. As far as secretions were concermed no estimates were made. Absorption took place under conditions where movement, at any rate, was an active factor.

The findings of Corlette and of Cathcart and Leathes regarded in a combined and complementary light reveal the following facts:-

Secretion Irom the intestine, was observed, unassociated with movement. Absorption was not ascertained.

$$
\text { (Corlette. Exps. I - V). }
$$

Movement in the intestine, was observed, unassociated with absorption.

Secretion was not ascertained.

(Cathcart \& Leathes. Exps. A \& B). 
Absorption from the intestine, was proved, associated with movement.

Secretion was not ascertained.

$$
\begin{gathered}
\text { (Catheart \& Ieathes Exps } 1,2,4,5,6,7,8 \text {, } \\
\qquad 9,10,11,12 \text {, and } 13 \text { ) }
\end{gathered}
$$

Absorption from the intestine, was proved associated with movement and secretion.

(Cathcart \& Leathes. Exp. 3).

The above analysis of evidence suggests the following possible features in the interplay of these three inherent attributes of intestinal function.

1. The independence of secretion upon movement and absorption.

2. The Independence of movement upon absorption.

3. The dependence of absorption upon movement and secretion.

\section{MOVEMENT.}

No previous work on peristalsis is quoted herein since enough evidence has been gathered from the foregoing reviews to furntsh a working hypothesis to the subsequent text. 


\section{BIBLIOGRAPHY. (SECTION III.A.)}

(1) BUSCH, W.: 'Beitrag zur Physiologie d. Verdauungsorgane.' Virchow's Archiv. 1858, xiv, $140-186$.

(2) THIRY, : 'Ueber eine neue Methode, den Dünndarm zu isolieren.' Sitzungsber. d. Wiener Akademie. $1864,1,77$.

(3) MOREAU, A.: 'De l'influence de la section des nerfs sur la production de liquides intestinaux.' Comptes Rendus. 1868, 1xvi, 554.

(4) BRUNTON, T.I. \& P. PYE-SMITH: 'Intestinal Secretion and Hovement.' British Assoc. Reports. 1874, 55, 63.

(5) DEMaNT, B.: 'Ueber die Wirkung des menschlichen Darmsafts! Virchow's Archiv. 1879, Ixxv, 419-430.

(6) VELIA, I.: 'Ein neues Verfahren zur Gewhnung reinen Darmsaftes und zur Feststellung seiner physiologischen Eigenschaften.' Woleschott's Untersuchungen. $1881, \times 111,40$.

'Nouvelle méthode pour obtenir le suc enterique pur et pour en fixer les propriêtés physioliques (Résumé).' Archives Italiennes de Biologie. 1881, i, 228.

(7) MARCKWATD, $\mathrm{H}_{\circ}$ : Veber Verdauung und Resorption Im Dickdarme des Menschen' (Aus d. phys. Inst. von Prof. Kuhne zi He1delberg). Virchow's Archiv. 1875, 1xiv, $505-539$.

(8) STARIIKG, E.H.: Starling's Principles of Human Physiology. 5th ed., 593. Iondon: J. \& A. Churchill. 
(9) CORLETTE, C.: 'An Experimental Research on excretion in the small intestine.' Jour. of Physiol. 1899 - 1900, xxv, 344. Lond on.

(10) HALSTEAD, : Amer. Jour. Med. Science N.S.

(1I) HERMANI, M.: Arch. of Physiol.

(12) BAUER, J.: 'Ueber d. Aufsaug. im Dick-und Dünndarm.' Zeit. f. Biologie. 1869, v.

(13) EICHHORST, H.: Cand. Med. aus Königsberg, 'Ueber die Resorption der Albuminate im Dickdarm' (Von der med. Fakultat der AlbertusUniversität zu Königsberg mit dem Preise gekrönt), Pflüzer's Archiv. 1871, iv, $570-662$.

(14) IEUBE, W.0.: 'Ueber die Ernährung der Kranken vom Mastdarm aus.' Deutsch. Archiv. 1 . klin. Medizin. $1872, x, 1-54$.

(15) CZFRTY, V. \& T. IATSCHENBERGER: 'Physiologische Untersuohungen verdaung und Resorption im Dickdarm des Menschen.' Virchow's Archiv. 1874, lix, 161 - 190.

(16) WARCKHATD, M.: Ueber Verdaung und Resorption im Dickdarme des Menschen' (Aus d. phys. Inst. von Prof. Ktihne zu Heidelberg). Virchow's Archiv. 1875, $1 \times 17,505-539$. 
(17) CATHCART, E.P. \& J.B.IFATHES: 'On the absorption of proteids from the Intestine.' Jour. of Physiol. 1905 - 1906, xxxi1i, 462. Iondon.

(18) SALVIOLI, : Du Bois Reymond's Archiv. 1880, Suppl. 95. 


\section{SECTION III.}

\section{OBSERVATIONS ON INTESTTNAL FUNCTION.}

\section{B. EXPER IIMENTS .}

The preceding evidence from experiments upon the dog provides, at least, a qualitative basis for further observations of intestinal function in man.

The experiments described in this section contain certain observations which I have made upon the daily faecal weight and faecal nitrogen values over two to three weeks, in individuals on a fixed diet of known nitrogen content.

From the experimental standpoint, and further to the previous work already mentioned, the diet represented the organic medium introduced into the alimentary system and the faeces represented the organic medium recovered from the bowel. The objective, therefore, was to ascertain to what extent faecal welght and faecal nitrogen values might be taken as an index of intestinal function.

\section{FXPER IMENTS XIX. - XXIII.}

THE REIATIONSHIP BEYWIXN FAECAT VEIGHT AND FAECAT NITROGEN AS AN INDEX OF INTESTIIAL FUNCTION.

\section{General Technique}

In the following experiments, selected individuals were given a standard diet for varyling periods. The faeces. were collected dally and weighed. The daily faecal nitrogen was determined in each oase. 
The standard diet contained 54.21 grms. of protein, $111.16 \mathrm{grms}$. of fat and and $251.04 \mathrm{grms}$. of carbohyarate with a total value of 2,172 alories...... The daily protein intake is seen to be low for an adult. I prescribed this type of aiet, however, to suit patients who might suffer from gastro intestinal symptoms. The dally nitrogen intake in the food was thus $\frac{54.19}{6.25}-8.6 \mathrm{grms}$.

Details as to the quantities and caloric values of the various food stufes comprising the standard diet are given in table 24.

The faeces were collected in JaconfTTE sheeting. The vessel into which the faeces were evacuated was lined with this material prior to defaecation, thus facilitating collection, and colncident urine was passed into separate vessels. Each specimen of faeces was dried on a steam bath and then weighed. In some of the experiments the ary weight only was recorded although in the majority, both moist and dry weights were recorded. The nitrogen in each specimen of faeces was estimated by the usual Kjeldahl method.

With the exception of myself, on whom I carried out the first series of observations, the subjects of experiment were out-patients attending the Hestern Infirmary, Glasgow. Intelligent patients who could be entrusted to understand and carry out instructions as to the weighing of food and the collection of freces were selected.

While the same daily routine, as regards exercise and rest, was not prescribed for all the subjects, each individual was asked to follow as constant a dally routine as possible throughout the period of observation. The weighing of faeces and the nitrogen estimations were carried out in the Physiological Chemistry Laboratory of the Department of Physlology at Glasgow University during 1927. 
TABLE 24

STANDARD DIET.

YA.M. WATER 10 OUNCES

\section{BREAKFAST.}

\begin{tabular}{|c|c|c|c|c|c|}
\hline & $\begin{array}{c}\text { AMOUNT } \\
\text { OZS. }\end{array}$ & $\begin{array}{c}\text { PROTEIN } \\
\text { Grms. }\end{array}$ & $\begin{array}{l}\text { FAT } \\
\text { Grms. }\end{array}$ & $\begin{array}{c}\text { CARBOAYDRATE. } \\
\text { Gyms }\end{array}$ & $\begin{array}{l}\text { CALORTES } \\
\text { Gims. }\end{array}$ \\
\hline ONE EGG & - & 8 & 6 & - & 86 \\
\hline WHITE BREAD & 2 & 4 & 0.5 & 30 & 140 \\
\hline BUTTER (Evesh) & 1 & 0.1 & 24 & - & $222 \cdot Y$ \\
\hline TREACLE & $\frac{1}{3}$ & 0.02 & - & 8.6 & 34.9 \\
\hline HOT WATER & 5 & $=$ & $=$ & $=$ & $=$ \\
\hline & TOTALS & $12 \cdot 12$ & 30.5 & 38.6 & 483.6 \\
\hline
\end{tabular}

LUNCH.

\begin{tabular}{l|c|c|c|c|c}
\hline & AMOUNT & PROTEIN & FAT & CARBOHYDRATE & CALORIES \\
\hline POTATOES & 4 & 2 & 0.01 & $22 . y$ & 24. \\
\hline BUTTER & 1 & 0.1 & 24 & - & $222 . y$ \\
\hline CABBAGE & 2 & 0.8 & - & 2.6 & $y \cdot 1$ \\
\hline BROWN BREAD & 2 & 2.5 & 0.5 & 26. & 120. \\
\hline ONE APPLE & 3 & - & - & 12 & 48. \\
\hline TREACLE & $\frac{1}{2}$ & 0.02 & - & 8.6 & 34.9 \\
\hline CHEESE (CTERM) & 1 & $y$ & 9 & 1. & 113. \\
\hline & TOTALS. & 12.42 & 33.51 & 312.9 & $569 . y$ \\
\hline
\end{tabular}

DINNER.

LPM. WATER 10 OUMCES.

\begin{tabular}{|c|c|c|c|c|c|}
\hline & $\begin{array}{c}1 M O U N T \\
025 .\end{array}$ & $\begin{array}{l}\text { PROTEIN } \\
\text { Grms. } \\
\end{array}$ & $\begin{array}{l}F A T \\
\text { Grme. }\end{array}$ & $\begin{array}{c}\text { CARBOH Y DRATE } \\
\text { GrmS. }\end{array}$ & $\begin{array}{c}\text { CALORIES } \\
\text { Grms. }\end{array}$ \\
\hline$B E E F$ (loin lean) & 4 & 20 & 12. & $=$ & 188. \\
\hline CABBAQE & 2 & 0.8 & - & 2.6 & $y \cdot 1$ \\
\hline BRONN BREAD & 2 & 2.5 & 0.5 & 26. & 120. \\
\hline TOMATOES & 2 & 0.5 & $=$ & 2 & 10. \\
\hline TAPIOCA & 1 & - & - & 25. & 100. \\
\hline PRUNES & 2 & 1 . & - & 40. & $164^{\circ}$ \\
\hline CREAM & 3 & 1.5 & 15. & 3. & 153. \\
\hline TREACLE & $\frac{1}{2}$ & 0.02 & $=$ & 8.6 & $34 \cdot 9$ \\
\hline \multirow[t]{2}{*}{ CHOCOLATE } & 1 & 1.3 & $y \cdot 4$ & $14 \cdot 34$ & 160.2 \\
\hline & TOTALS & $2 y \cdot 62$ & 34.9 & 24.54 & 934.2 \\
\hline
\end{tabular}

10P.M. WATER 10 OUNCES.

SUPPER.

\begin{tabular}{|c|c|c|c|c|c|}
\hline & $\begin{array}{c}\text { AMOUNT } \\
\text { OZS }\end{array}$ & $\begin{array}{c}\text { PROTEIN } \\
\text { GYMS }\end{array}$ & $\begin{array}{l}\text { A } T \\
\text { Arms }\end{array}$ & $\begin{array}{c}\text { CARE A LYORASE. } \\
\text { GRME. }\end{array}$ & $\begin{array}{l}\text { CALORILS } \\
\text { Grms }\end{array}$ \\
\hline BREAD & 1 & 2 & 0.25 & 75 & Yo. \\
\hline BUTTER & $\frac{1}{2}$ & 0.05 & 12 & - & $111.5^{\circ}$ \\
\hline & TOTALS. & 2.05 & $12 \cdot 25^{\circ}$ & 15 & $181 \cdot 5$ \\
\hline
\end{tabular}

\begin{tabular}{|c|c|c|c|c|}
\hline & $\begin{array}{l}\text { PROTGIN } \\
\text { GYMS. }\end{array}$ & $\begin{array}{l}\text { FAT } \\
\text { Grms. }\end{array}$ & $\begin{array}{c}\text { CAR BOHY ORATE } \\
\text { Grms. }\end{array}$ & $\begin{array}{c}\text { CALORIES } \\
\text { GrnS. }\end{array}$ \\
\hline BREAKFAST & $12 \cdot 12$ & 30.5 & 38.6 & $483 \cdot 6$ \\
\hline LUNCH & $12 \cdot 42$ & 33.51 & $3 / 2.9$ & $569 \cdot y$ \\
\hline DINNER & $2 y \cdot 62$ & $34 \cdot 9$ & $124 \cdot 54$ & $93 y .2$ \\
\hline SUPPER & $2 \cdot 05$ & $12.25^{\circ}$ & 15 & $181 \cdot 5$ \\
\hline TOTALS PER DAY & $54 \cdot 21$ & $111 \cdot 16$ & $261 \cdot 04$ & $2,1 y^{2} \cdot 0$ \\
\hline
\end{tabular}


EXPER IIMENT XIX.

The observations in this instance were carried out upon myself. The standard diet was taken for a period of fourteen days. Prior to taking this diet an ordinary mixed diet, eaten according to appetite, had been the daily routine. It differed from the standard diet only in so far as the addition of bacon at breakfast, fish at lunch and potatoes at dinner were concerned. The protein content was definitely higher than that of the standard diet. The examination of the freces continued for a further period of seven days after the period of standard diet had terminated and ordinary mixed diet, wasumed. The first two specimens of faeces were examined on the two days preceding the commencement of the standard diet. During the period of these observations, which extended over twenty-three days, the daily routine included the usual commitments of hospital and general practice, and was more or less constant throughout as regards work output. Health was good with freedom from symptoms. The results are recorded in table $\$ 0.25$. The figures pertaining to weight of dry faeces and nitrogen percentage are represented graphically (Fig. WIII). 


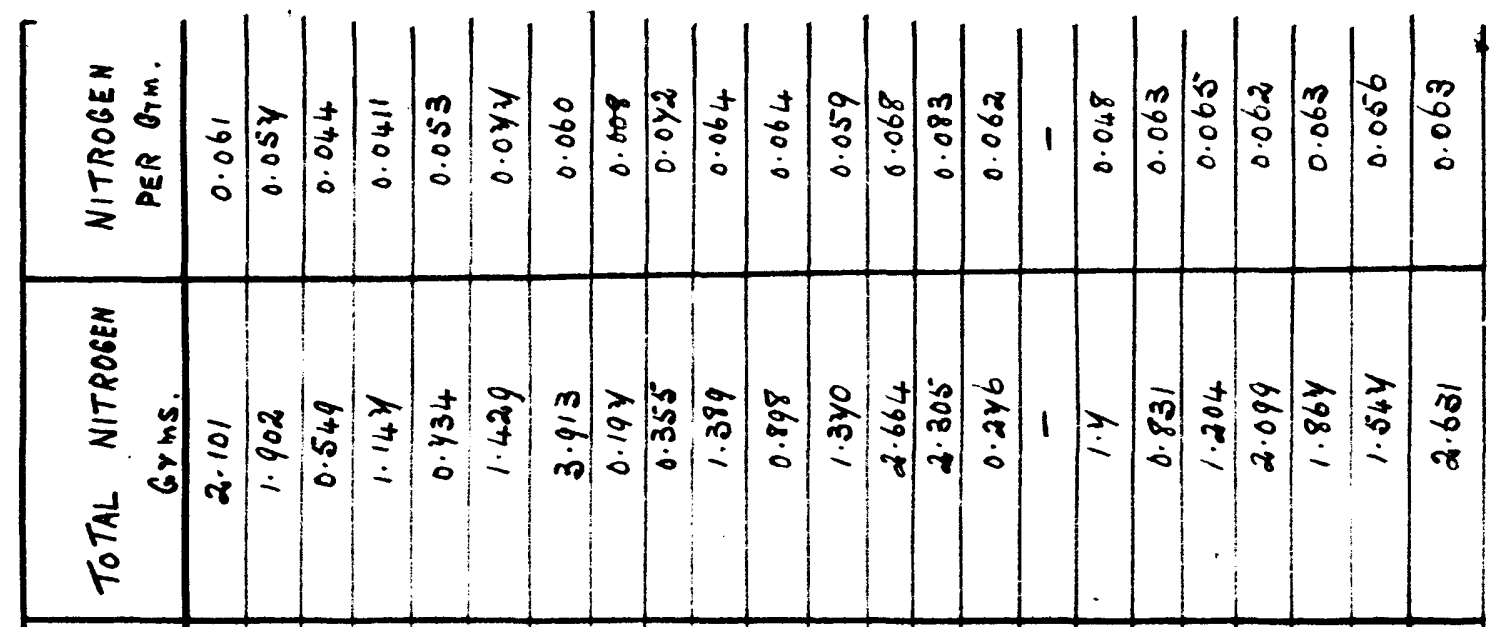

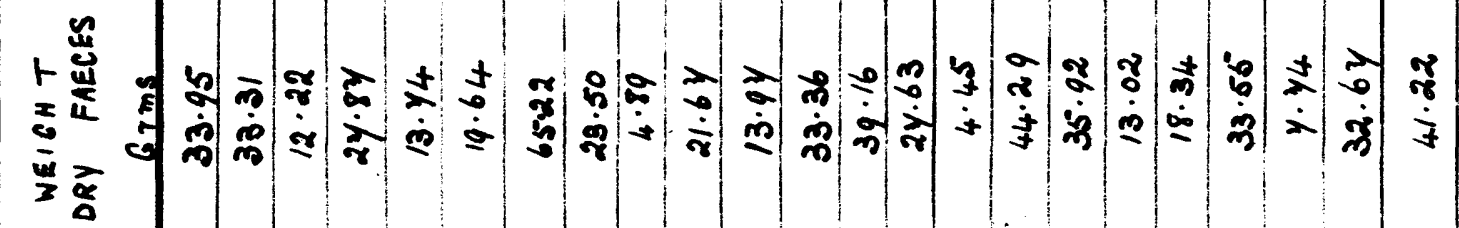

$b$
$d$
4
$\frac{1}{4}$
$f$

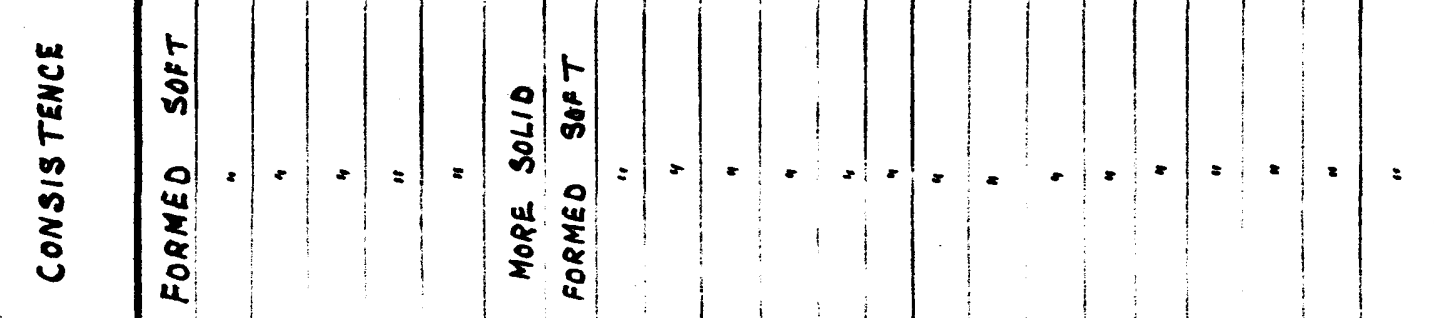

$\ddot{6}$

$\frac{11}{10}$

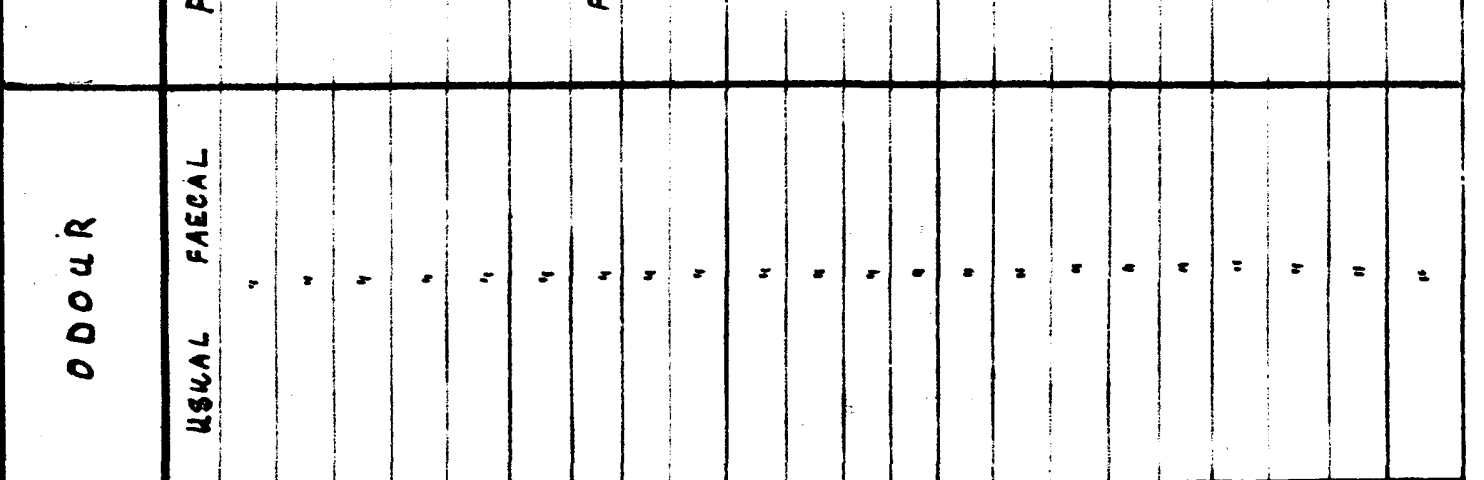

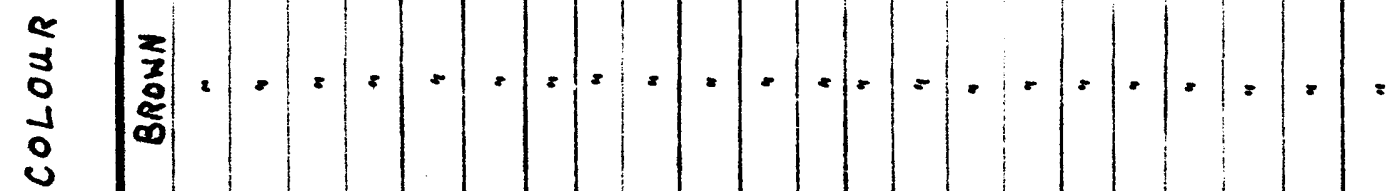

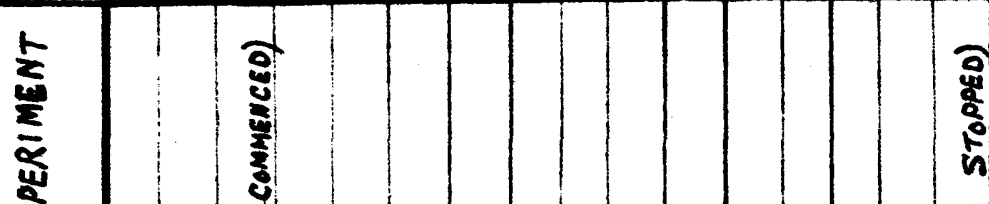

के

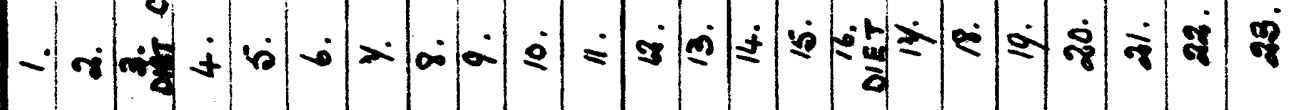

s

$\overline{\mathbf{z}}$

章 


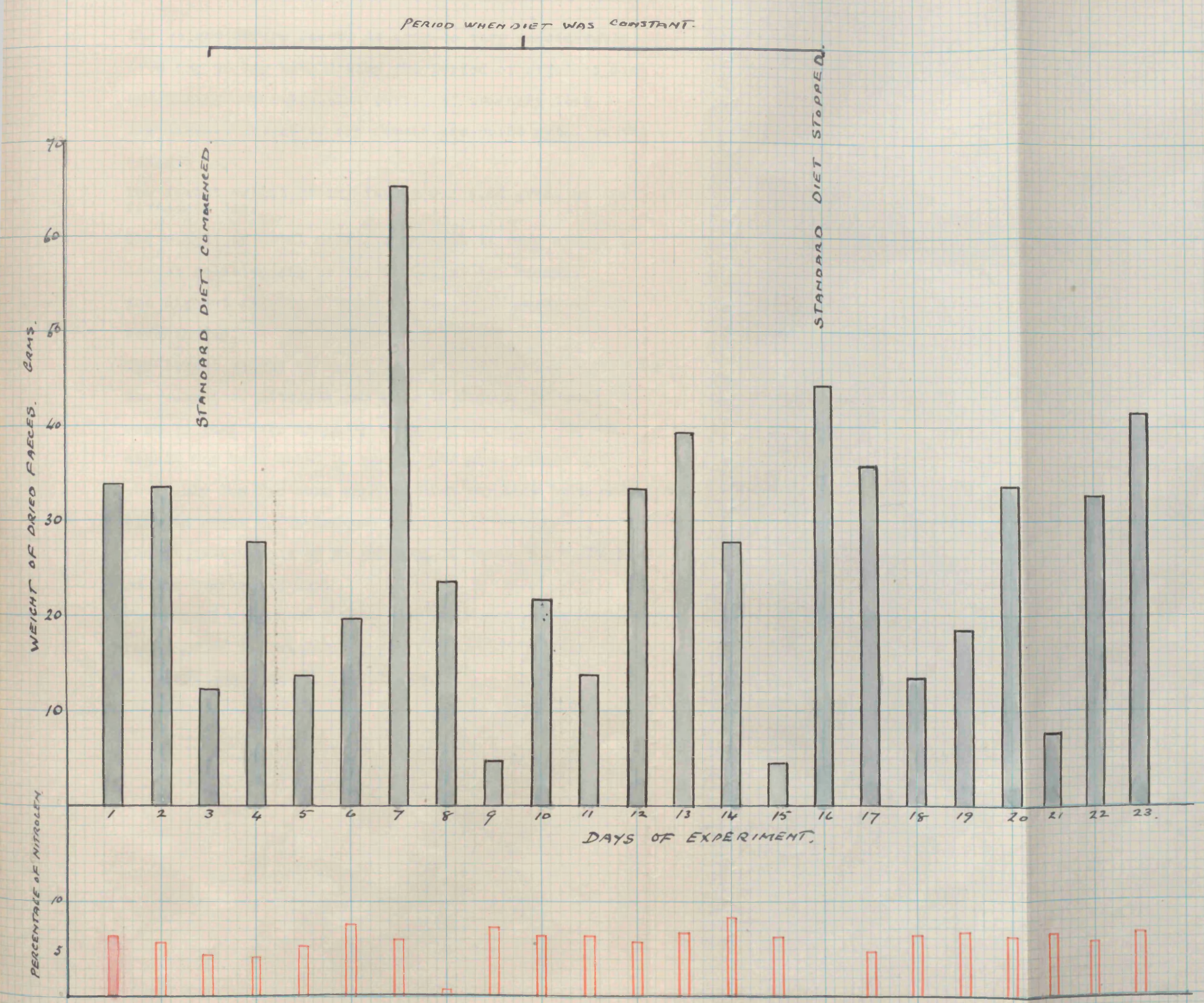


Comments on Table and Graphic Record of Experiment XIX.

The weitht of ary faeces is seen to vary considerably from day to day both during the period of standard diet and during the subsequent period of ordinary diet. The highest weight of dry faeces was 65.22 grms. on the seventh day.

The lowest weight of dry faeces was 4.45 grms. on the fifteenth day.

The weight of total nitrogen is seen to vary almost in airect relationship to the weight of ary faeces.

The highest weight of total $N$. was 3.913 grms. on the seventh day.

The lowest weight of total $\mathrm{N}$. was 0.197 on the eighth day. The weight of nitrogen per grm. of faeces, however, is seen to vary very slightly from day to day. On the eighth day both total $N$. and $N$. per grm. values are obviously low for some reason which may have been associated with an error in technique.

The highest weight of N. per grw. of freces 0.083 grms. on the fourteenth day.

The lowest weight of $\mathrm{N}$. per grm. of faeces (excluding the readings of the eighth day for the reason mention above) was 0.411 grms. on the fourth day. 


\section{EXPERIMENT XX.}

A second series of observations were carried out upon myself extending over a period of eleven days. On this occasion the standard diet was not taken. An ordinary mixed diet,according to appetite, was taken as a daily routine. It was desired to ascertain whether there was any difference between faecal weight and the faecal nitrogen values of this experiment and those of the preceding one in which the diet was controlled. The other conditions as regards daily routine were similar to those of Experiment XIX. The results are recorded in table 26. The figures pertaining to weight of dry faeces and nitrogen percentage are represented graphically (Fig. TX ). 


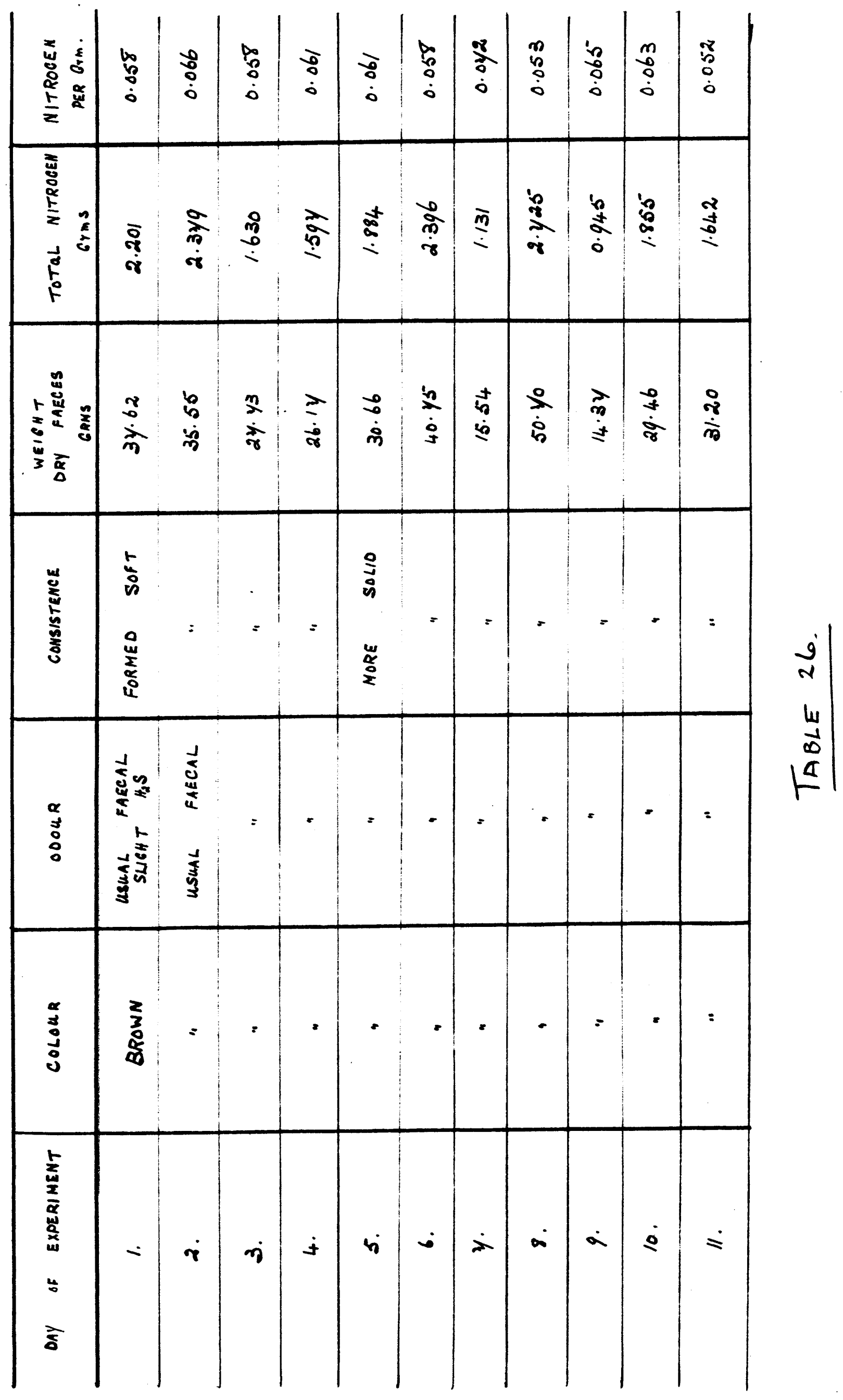


Exp $\overline{x x}$

FIE IX DAMY VARIATIONY IIY WEIEHT OF DRIED FAECES ATD FaECAL MITREEY ON ORDIMARY DIET

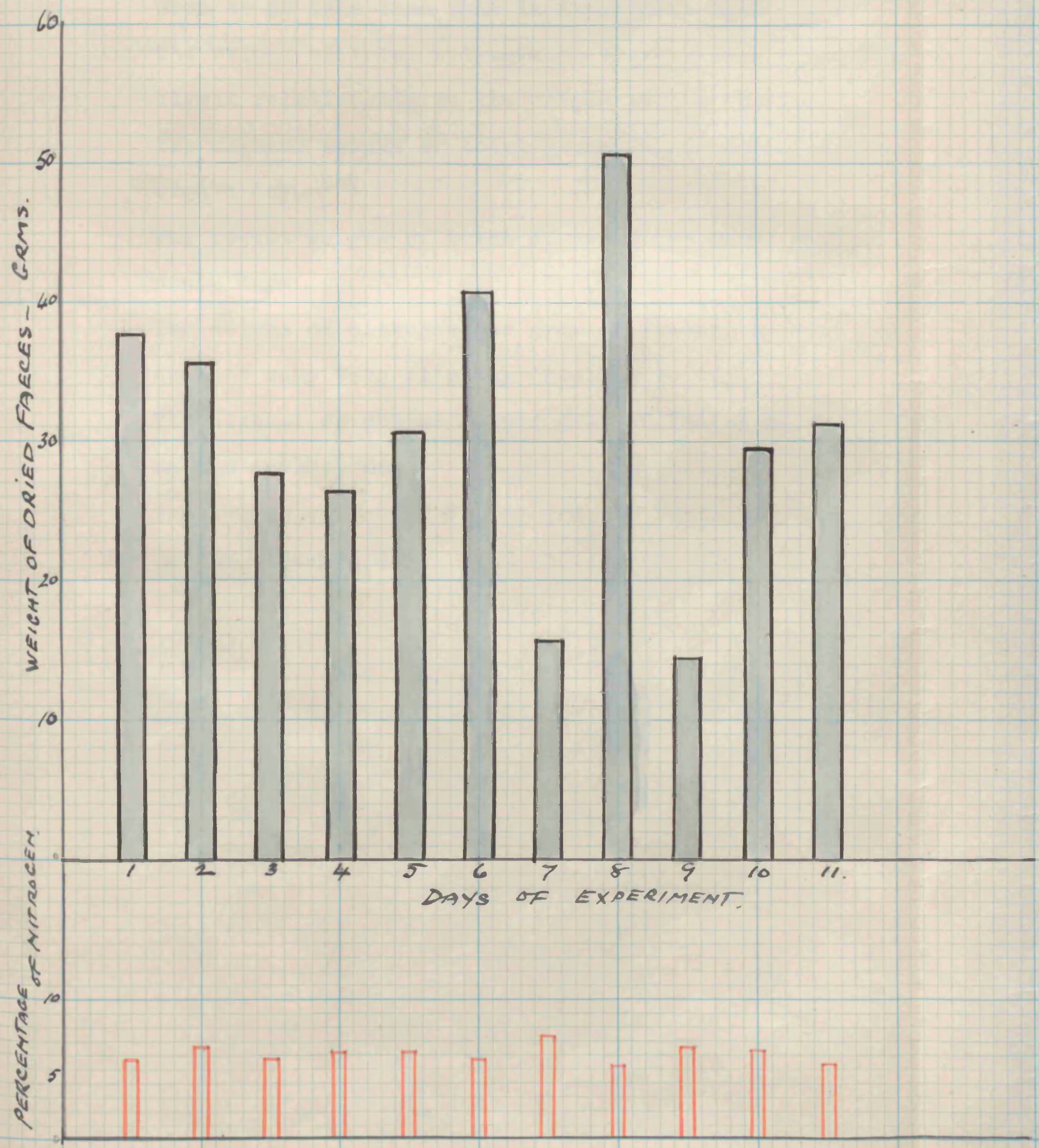




\section{Comments on Table and Graphic Record of Experiment XX.}

The weight of dry faeces is seen to vary considerably from day to day on ordinary diet eaten according to appetite. The highest weight of dry faeces was $50.70 \mathrm{grms}$. on the eighth day.

The lowest weight of ary faeces was 14.37 grms. on the ninth day.

The range of variation in weight of dry faeces is thus seen to be less than that in Experiment XIX. The weight of total nitrogen is seen to vary almost in direct relationship to the weight of ary faeces. The highest weight of total $\mathbb{N}$. was 2.725 grms. on the eighth day.

The lowest weight of total $N$. was $0.945 \mathrm{grms}$. on the ninth day.

The weight of nitrogen per grm. of faeces, however, is seen to vary very slightly from day to day.

The highest weight of $N$. per grm. of faeces 0.072 grms. on the seventh day.

The lowest weight of N. per grm. of faeces was 0.052 grms. on the eleventh day. 


\section{EXPERIMENT XXI.}

The subject of this experiment was a married woman ged 48 years, suffering from visceroptosis. She was given the standard diet over a period of fourteen days during which time the faeces were collected dally. Her dally routine was regular and constant throughout, consisting of housework and $\frac{1}{2}$ hour rest periods in the recumbent posture before each of the three principal meals. The patient was practically symptom-tree during the period of observation and stated that she had been able to eat all the prescribed quantities of food. In this experiment the Iresh Iaeces, which were conslsteñtly solfd. were welghed prior to drying. The results are recorded in table 27. The figures pertaining to weight of ary faeces and nitrofen percentage are represented graphically $(\mathrm{Fig} \cdot \underline{\underline{X}})$. 


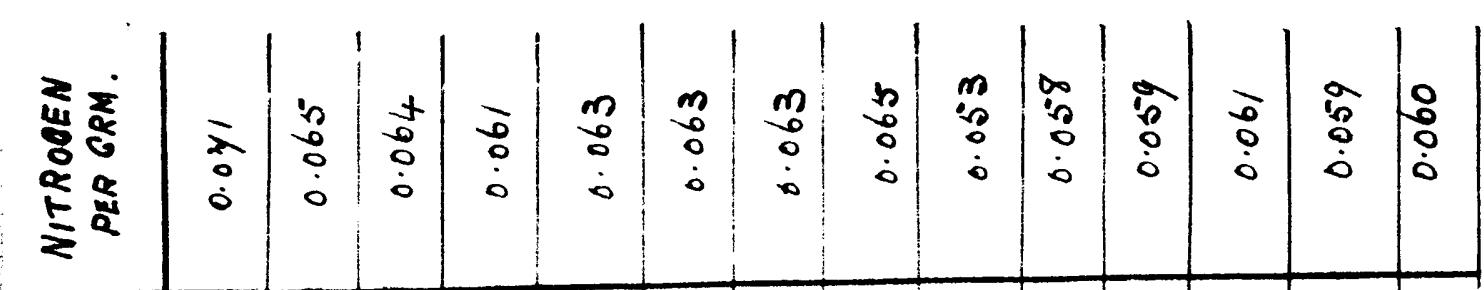

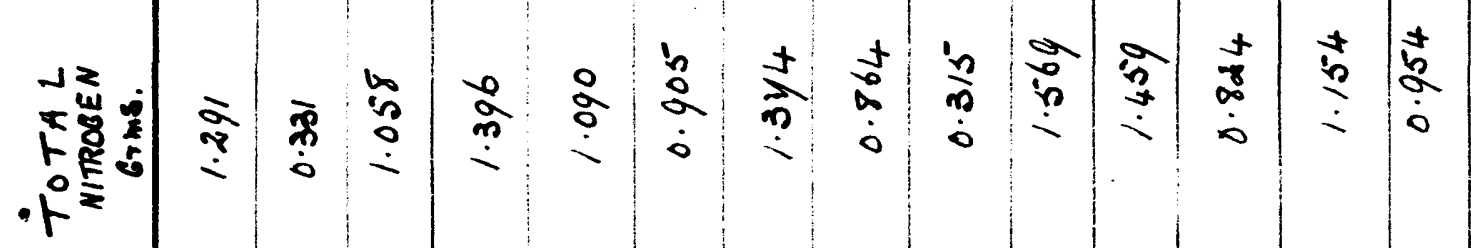

○

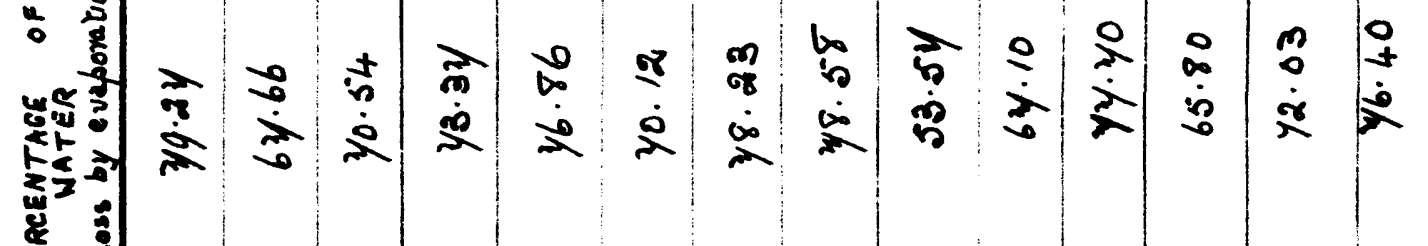

$\sqrt{5}$

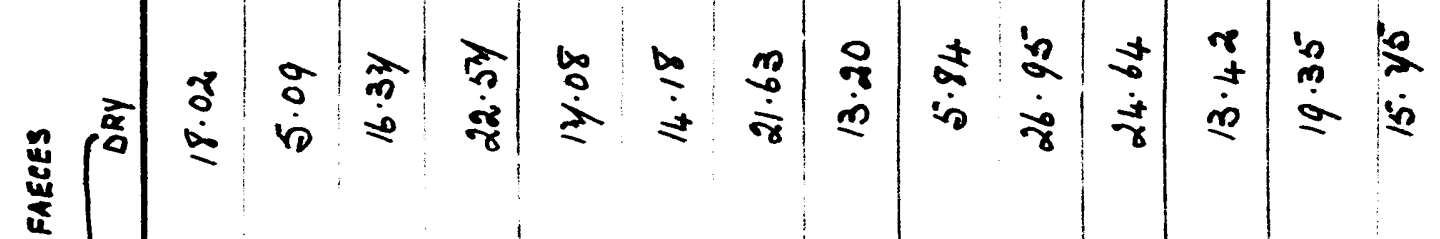

(1)

날

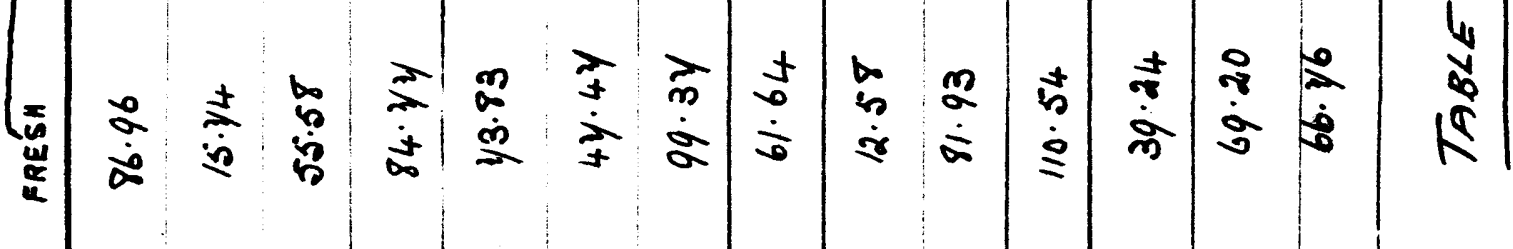

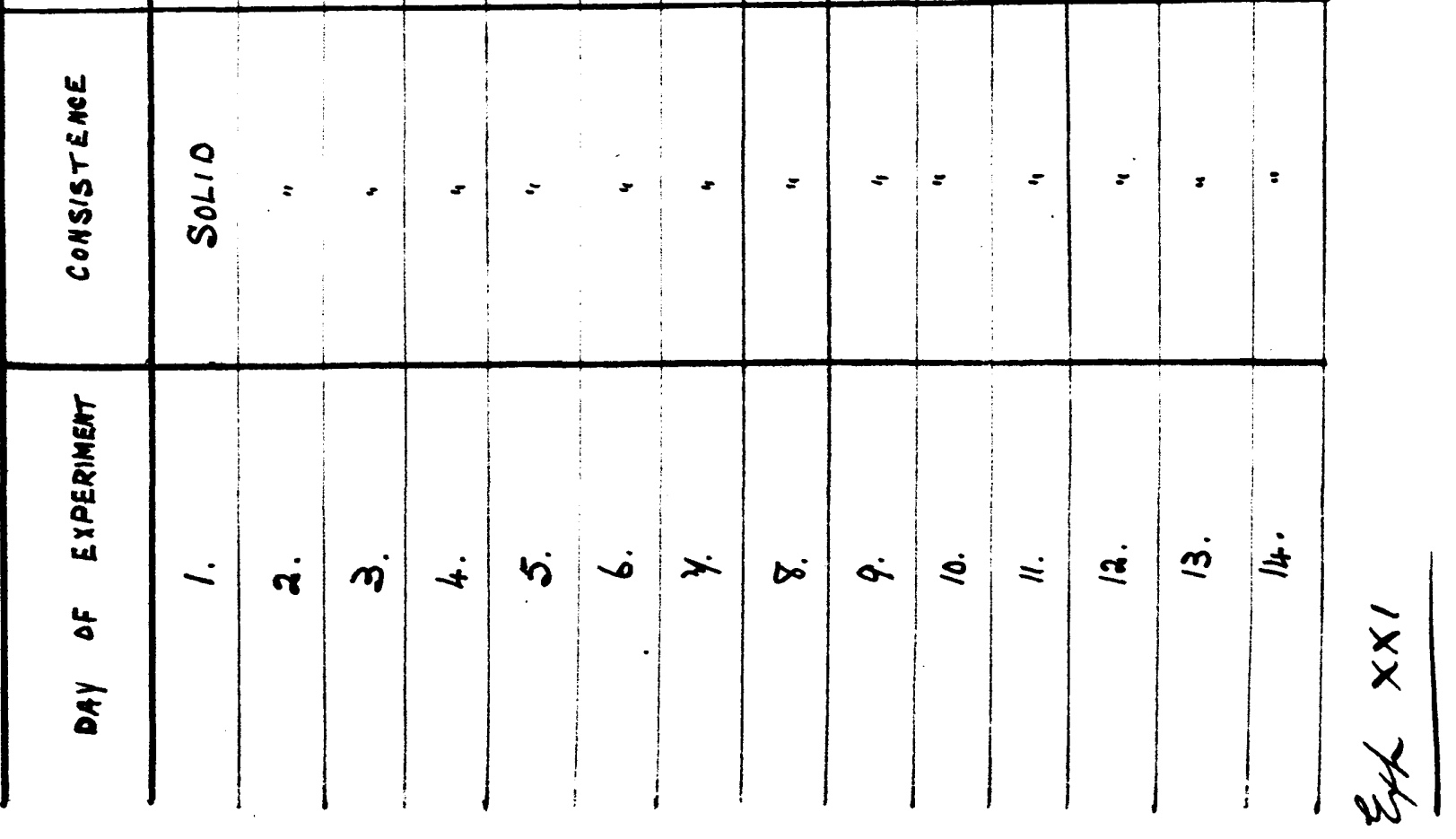




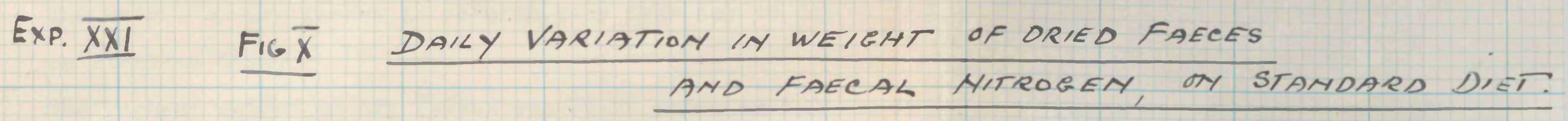

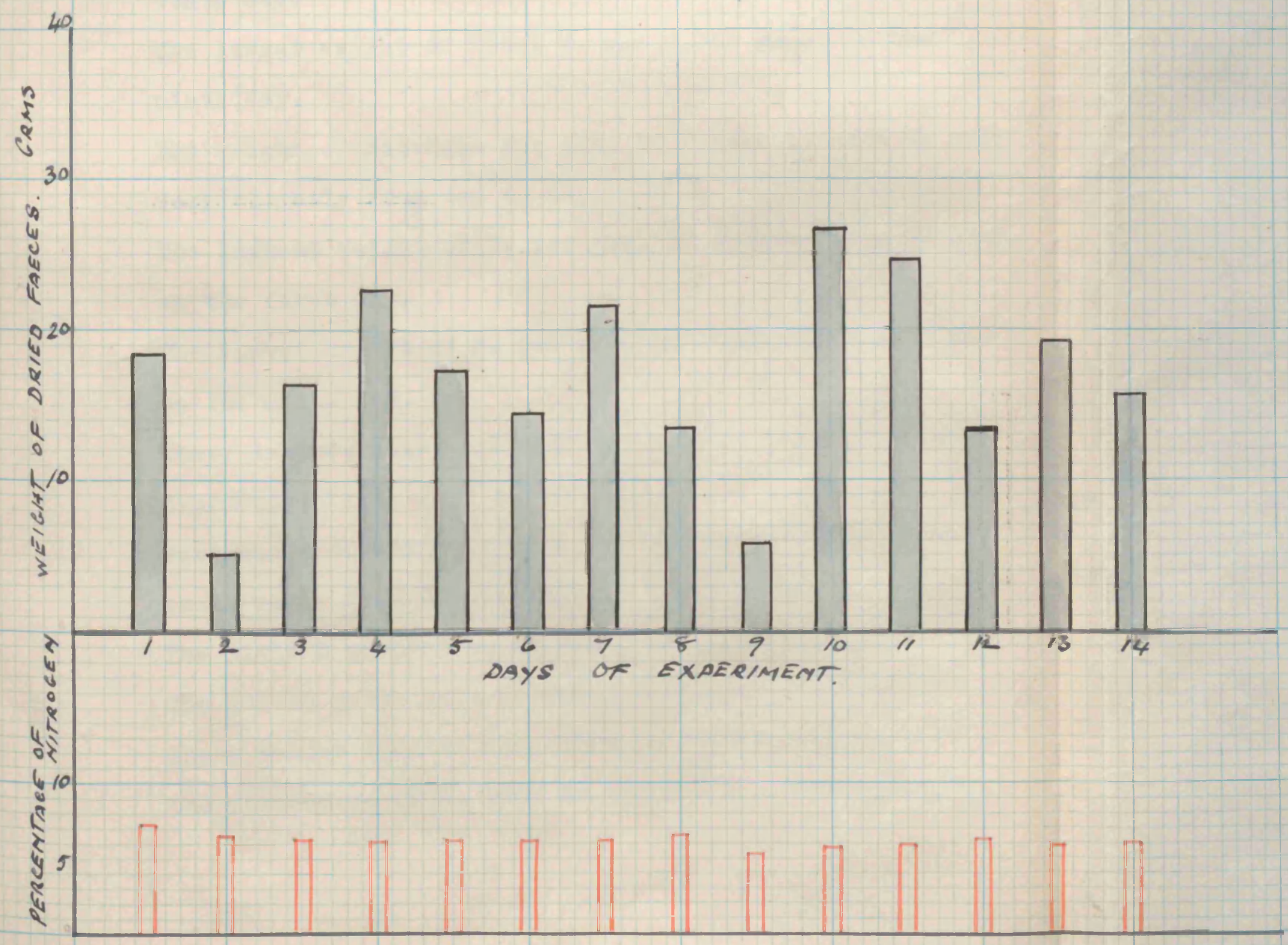


Comments on Table and Graphic Record of Experiment XXI.

The weight of dry faeces is seen to vary from day to day, on standard diet.

The highest weight of dry faeces was $26.95 \mathrm{grms}$. on the tenth day.

The lowest weight of dry faeces was 5.09 grms. on the second day.

The range of varlation in weight of ary faeces is seen to be considerably less than that in Experiments $X I X$. and $X X$. The daily weights are, in general, less than those of the two preceding experiments.

The weight of total nitrogen tends to vary in direct relationship to the weight of ary feaces.

The highest weight of total N. was 1.569 grms. on the tenth day.

The lowest weight of total $N$. was 0.315 grms. on the ninth day.

The weight of nitrogen per grm. of faeces is seen to vary very slightly from day to day.

The highest weight of $N$. per grm. of faeces vas 0.071 grms. on the first day.

The lowest weight of $N$. per grm. of faeces ras 0.053 grms. on the ninth day.

These latter values are almost equal to those obtained in Experiment $\mathrm{XX}$.

Percentage of water is also seen to vary within comparatively small range from day to day.

The highest percentage of water $79.27 \%$ on the first day. The lowest percentage of water $53.57 \%$ on the ninth day. These values tend to vary more in direct relationship to the percentage of $\mathbb{N}$. than to the weight of dry faeces. 


\section{EXPERIMENT XXII.}

The subject of this experiment was a man aged 27 years suffering from duodenal ulcer. He was given the standard diet over a period of sixteen days during which time the faeces were collecte daily. He was unemployed and his dally routine was more or less constant as regards periods of rest and walking exercise. H1s duodenal symptoms were quiescent throughout and he stated that he had been able to eat the prescribed quantities of food with the exception of prunes on several days. In this experiment the fresh faeces, which were consistently solid were weighed prior to drying. The results are recorded in table 28. The figures pertaining to weight of dry' faeces and nitrogen percentage are represented graphically (Fig. $\overline{X I}$ ).

TABLE $28 d$ 


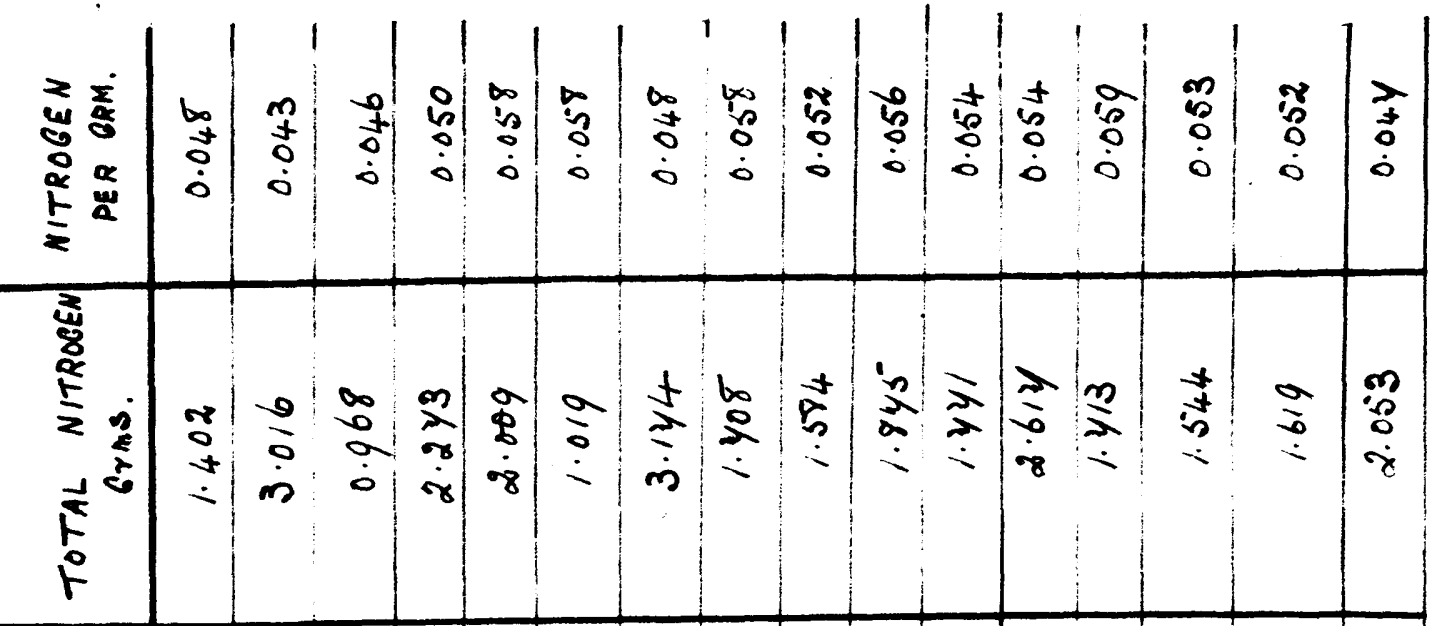

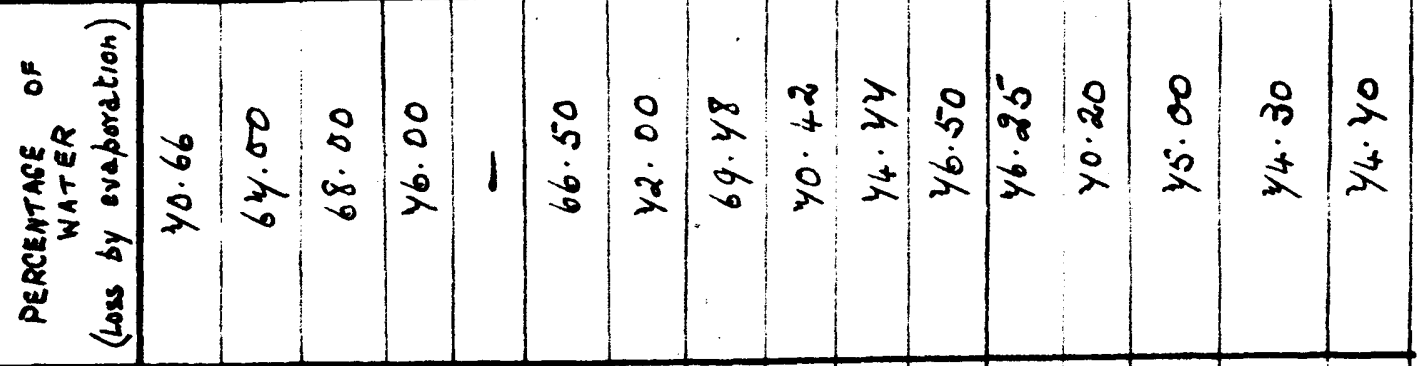

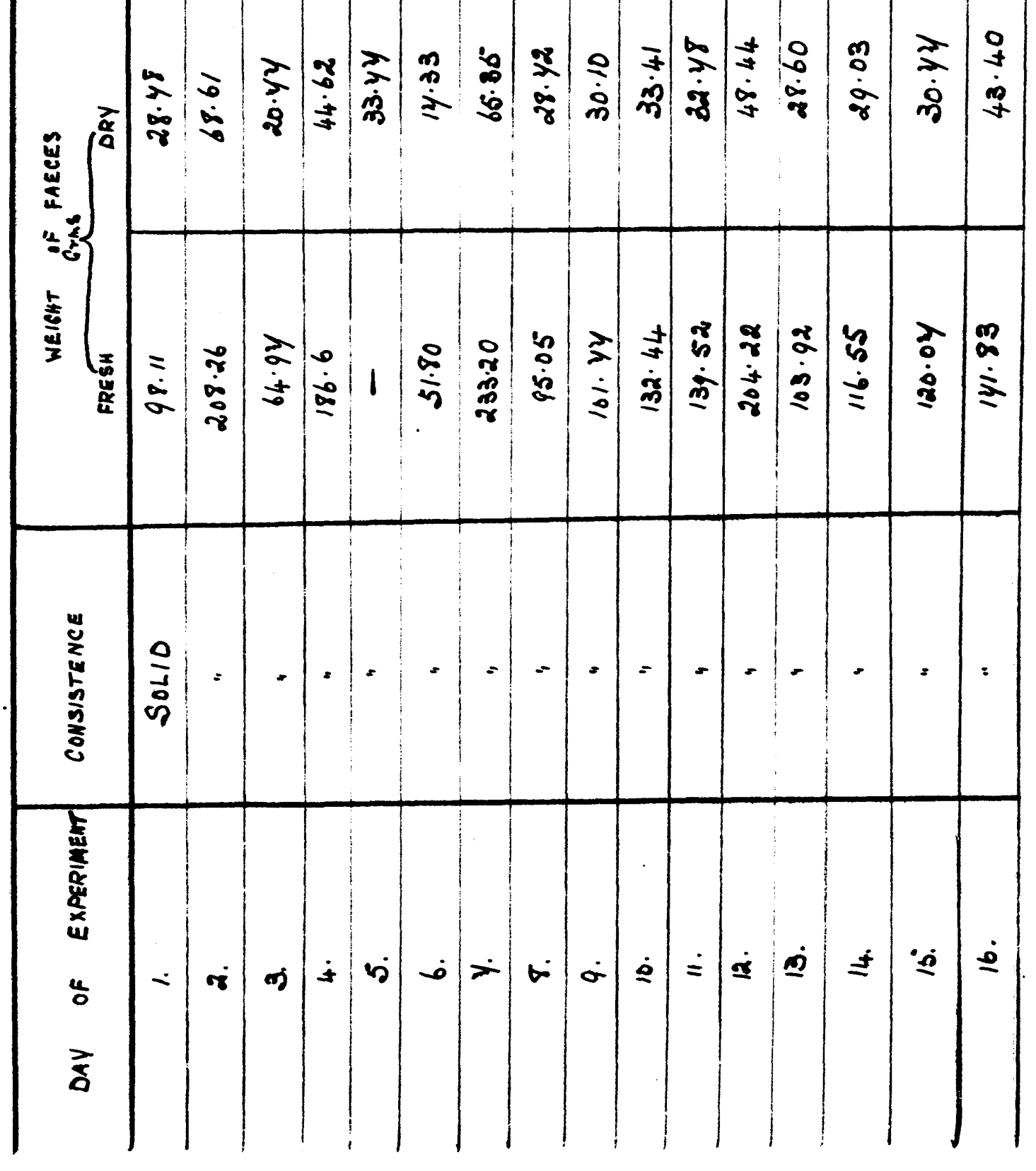

$\begin{aligned} & 0 \\ & 0 \\ & 4 \\ & 0 \\ & 0 \\ & 0\end{aligned} \mid$ 
EXP. $\overline{X X I I}$ FIG $\underline{\overline{X I}} \frac{\text { DAILY VARIATION IN WEIGHT OF DRIEA FAECES }}{\text { AMD FAECAL MITROEEM ON STAMDARD DIET. }}$

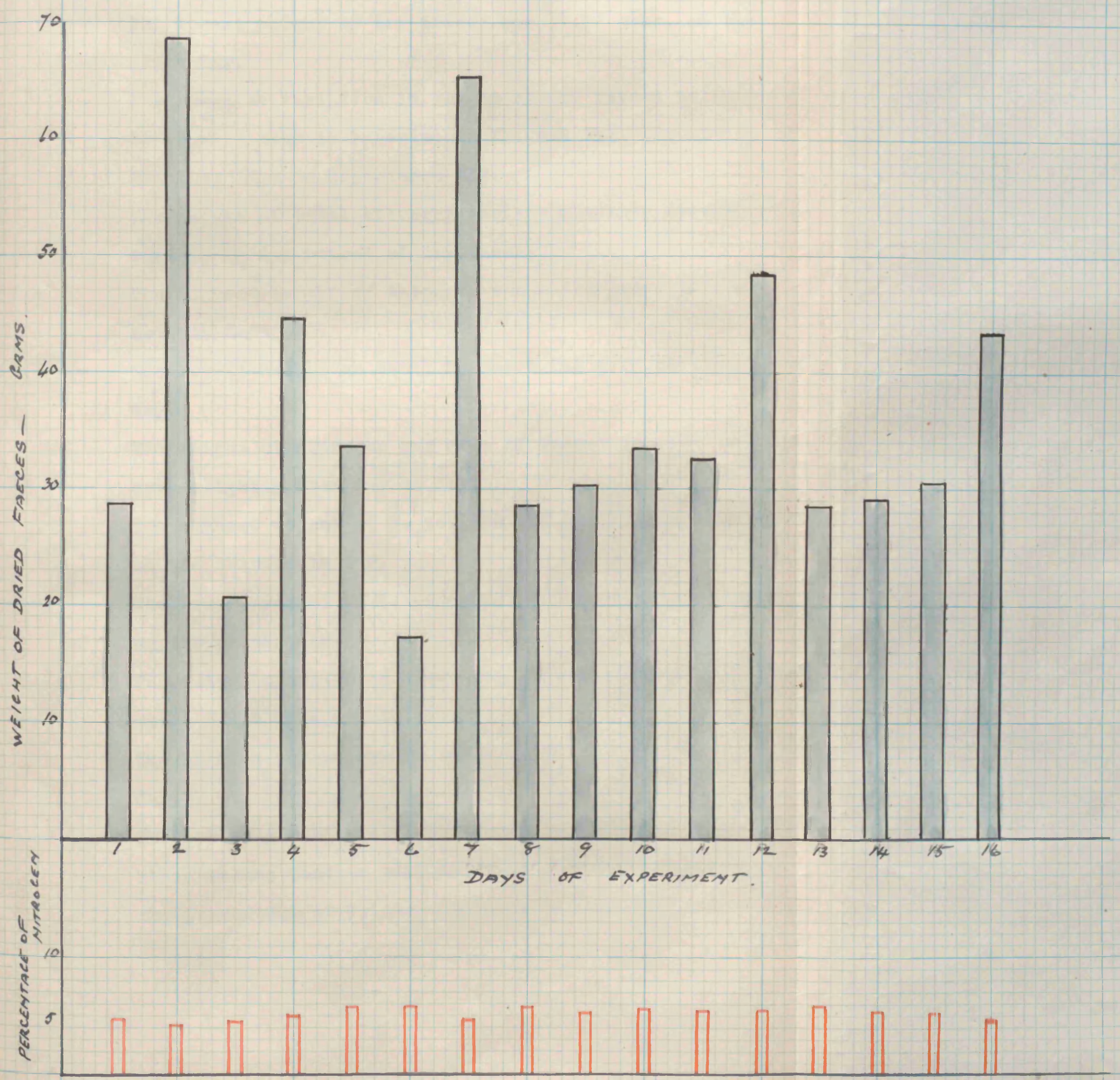


Comments on Table and Graphic Record of Experiment XXII.

The weight of dry feeces is seen to vary from day to day, on standard diet.

The highest weight of dry faeces was $68.61 \mathrm{grms}$. on the second day.

The lowest weight of dry faeces was 17.33 grms. on the sixth day.

The range of variation in weight of ary faeces is seen to be greater than in Experiments XX. and XXI. and almost as great as that in Experiment XIX.

The weight of total nitrogen varies in almost direct relatIonship to the weight of dry faeces.

The highest weight of total $N$. was 3.174 grms. on the seventh day.

The lowest weight of total $\mathbb{N}$. was 0.968 grms. on the third day.

The welght of nitrogen per grm. of faeces is seen to vary very slightly from dey to day.

The highest weight of $N$. per grm. of faeces 0.059 grms. on the thirteenth day.

The lowest welght of $N$. per grm. of faeces 0.043 grms. on the second day.

Percentage of water is also seen to vary within comparatively small range from day to day.

The highest percentage of water $76.50 \%$ on the eleventh day.

The lowest percentage of water $66.50 \%$ on the sixth day. These values tend to vary more in direct relationship to the percentage of $N$. than to the weight of ary faeces. 


\section{EXPERIMENT XXIII.}

The subject of this experiment was a man, aged 42 years, suffering from optic neuritis which was considered to be of toxic origin. He was given the standard diet over a period of fourteen days during which time the faeces were collected daily. He was unemployed and his daily routine was more or less constant as regards periods of rest and walking exercise. His ocular symptoms were persistent during the period of observation. He stated that he had been able to eat the prescribed quantities of food throughout the experiment. In this experiment the rresh faeces, which were consistently solid, were weighed prior to drying. The results are recorded in table 29. The figares pertaining to weight of ary faeces and nitrogen percentage are represented graphically $(F i g \cdot \bar{x} / 1)$.

TABIT: 29.1 
EXP. XXIII FIEXII DAILY VARIATIOY IN WEIEHT OF ORIED FAECES

AND FAECAL MITROCEN ON STAMOARD DIET:

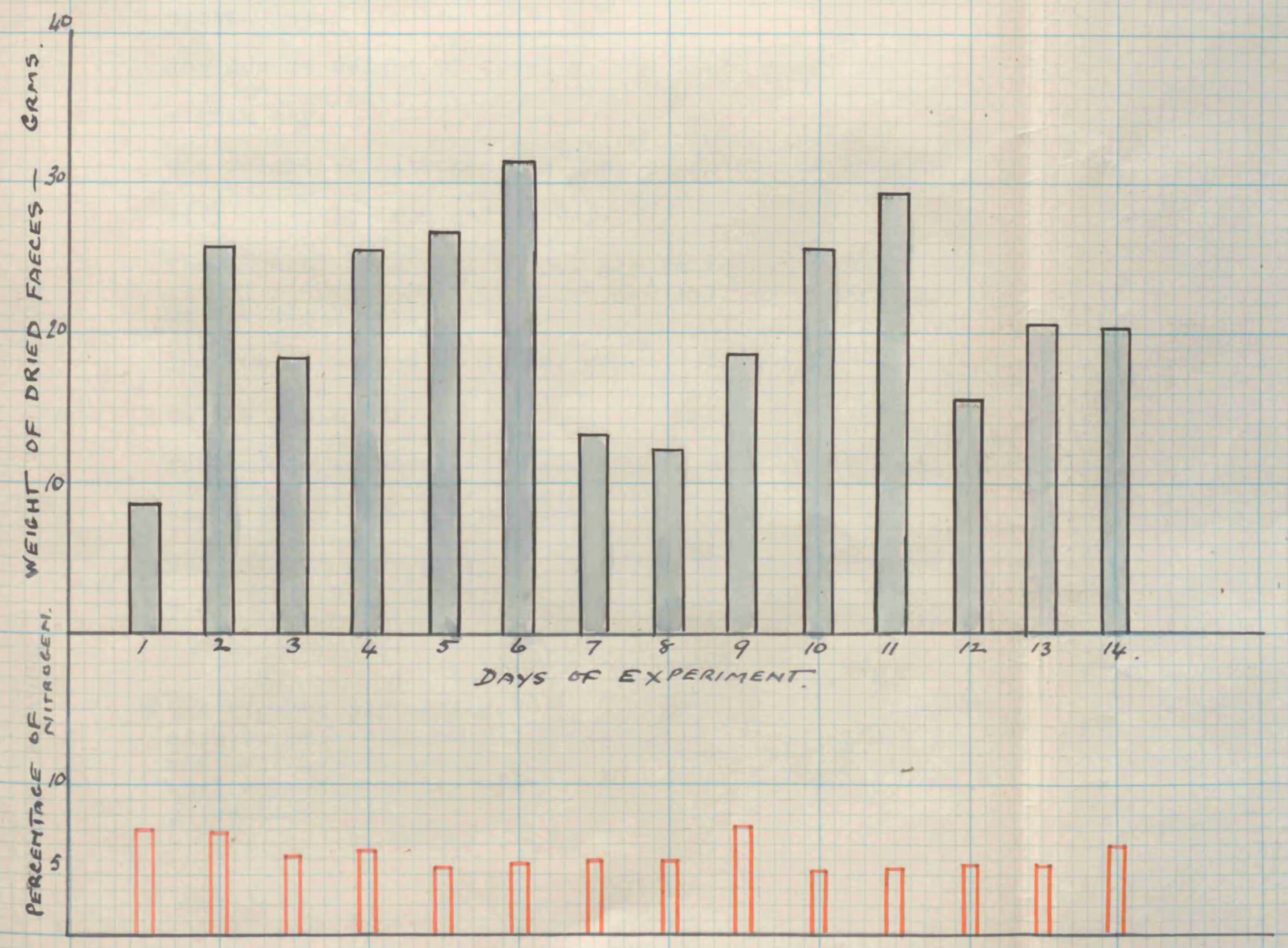


Comments on Table and Graphic Record of Experiment XxIII.

The weight of ary faeces is seen to vary from day to day on standard diet.

The highest weight of dry faeces was 31.45 grms. on the sixth day.

The lowest weight of dry freces was 8.88 grms. on the first day.

The range of variation in weight of dry faeces is seen to be considerably less than that in Experiments $\mathrm{XIX}$., XX., and XXII. The daily weights, in general, like those of Experiment XXI. are less than those of the other experiments.

The weight of total nitrogen varies in almost direct relationship to the weight of dry faeces.

The highest weight of total N. was $1.796 \mathrm{grms}$. on the second day.

The lowest weight of total $\mathbb{N}$. was 0.591 grms. on the eighth day.

The weight of nitrogen per grm. of faeces is seen to vary very slizhtly from day to day.

The highest weight of $N$. per grm of faeces ws 0.071 grms. on the ninth daj.

The lowest weight of $N$. per grm. of faeces nias $0.042 \mathrm{grms}$. on the tenth day.

Percentage of water is also seen to vary within comparative: small range from day to day.

The highest percentage of water was $80.81 \%$ on the ninth day. The/

The figures pertaining to $N$. per grm. of dry faeces may also be expressed in percentage of dry faeces. Since they are represented graphically. In this latter form they will accordingly be referred to subsequently in terms of percentage. 
The lowest percentage of water was $65.62 \%$ on the thirteenth day.

These values tend to vary more in direct relationship to the percentage of $N$. than to the weight of dry faeces.

\section{Discussion of Results in Experiments XIX. - XXIII.}

Considerable differences in the weights of dry faeces were observed in different individuals on the same diet. Daily variations in the weight of ary feeces were observed in the same individual on a fixed diet over a period of 14-16 days.

Very slight. alfferences in the percentages of nitrogen in the faeces were observed in aifferent individuals on the same diet.

Very slight daily variations in the percentage of nitrogen in the faeces were observed in the same individual on a fixed diet over a period of 14-16 days.

Very slight differences in the percentages of water in the facces were observed in different inditiduals on the same diet.

Very slight dally variations in the percentage of water in the faeces were observed in the same individual on a fixed diet over a period of 14-16 days.

Corlette, in his experiments already quoted, found considerable differences in the weights of intestinal contents in different dogs on the saffe diet.

In the same experiments, he also found very slight differences in the percentages of nitrogen and of the percentages of water in the intestinal contents in different dogs on the same diet. 
My own results pertaining to the differences in the weights of dry faeces in afferent individuals on the same diet and the slight differences in the percentages of nitrogen and of water in different individuals on the same diet agree qualitatively with those of corlette. In both his experiments and in my own a substance was recovered from the lumen of the intestine which varied in bulk in different individuals on the same diet but which possessed an approximately constant percentage of nitrogen and of water.

Corlette's quantitative results pertained entirely to an accumulation of secretion as distinct from the introduction of food material, in an isolated segment of intestine in the dog. His figures, representing the welghts of intestinal contents in different dogs, were indications of the extent of individual intestinal secretory function.

On the basis of this qualitative similarity in experimental results in the dog and in man, a suggestion is put forward that differences in weights of dry faeces in different individuals on the same diet are due to individual differences in the extent of secretory function. In different individuals. Furthermore, on the same basis and in the light of my experiments on the daily variation in the ary weight of faeces and the very slight daily variations in percentage of nitrogen and of water in the same individual on a fixed diet for a given period, the suggestion is put forward that daily variation in the weight of dry faeces in one individual is primarily due to dally variation in the extent of intestinal secretory function in that individual. ahimation? 
Discussion on the possible relationship between secretion and irovement.

Towards these deductions, might be urged the participation of intestinal movement in faecal weight. The fact that the faeces are expelled to the exterior is in itself an index of movement. Any diminished power of movement would obviously be responsible for an incomplete expulsion and consequently a diminished amount of faeces. It would seem that excessive movement, on the other hand, need not necessarily be responsible for an increased amount of faeces unless secretion, primarily, within the lumen of the bowel, has been sufficiently excessive to excite such a translation to the exterior.

In order to clarify the conception of the relationship between secretion and movement it is perhaps justifiable

- to resort to analogy. The passage of urine to the exterior is primarily a matter of secretion and secondarily a matter of movement. The same applies to the passage of a sputum to the exterior.

Up to the present time, the clinical conception of the passage of faeces to the exterior would seem to have given to movement, a primary plase. "The movement of the bowels" is perhaps one of the most frequently used terms in medieal practice. Much therepeutic effort has been directed towards the regulation of intestinal movement and little or no place, in working hypothesis, has been given to regulation of intestinal secretion. The results of Experiments XIX. - XXIII. would suggest that the arrival of faeces at the exterior is primarily a matter of secretion and secondarily a matter of movement. 
From daily variations in the weight of the dried faeces, evidence may be obtained as to daily variations in secretion from the intestine. From what source may evidence be obtained as to absorption from the intestine, absorption of the products of putrefaction? In answer, the subject of indicanuria invites consideration. 


\section{SECTION IV.}

\section{INDICANURIA.}

\section{A. HISTORICAI REVIEW.}

Wadsworth (1) has defined indicanuria as the occurrence of a substance in the urine which may be made to yield a blue colour by the application of hydrochloric acid and an oxidisine agent, in given proportions. He states further that the blue colour may occasionally be present in the urine on passing, it may enter into the composition of urinary calculi or it may be developed spontaneously in the urine on standing.

Indigo blue was first recognised in human urine by Prout (2) in 1840. In this connection Prout's own statement is of interest.

"I once met with an instance in which indigo was occasionally "voided in the urine in considerable quantity. The patient "was a middle aged man of a nervous temperament. He was "in the habit of takine Seidlitz powders; and the indigo "most generally appeared in the urine in the form of a dark "blue sediment, after taking one of the powders. The "quantity was so considerable on one occasion as to allow "of its being collected and examined, when it was found to "possess all the properties of indigo, and was obtained in "a state of purity by sublimation. I had expected to "find it consist of Prussian blue."

Although blue coloured urines had been described before this time the actual nature of the colouring matter had not been defined. Five years later Heller (3) described a plgmented substance which he called uroxanthine in the 
urine of cholera patients. He found also that this substance could be broken down into a blue andired pigment, uroglaucine and urrhodine respectively. Hellex, however, did not recognise the identity of his uroglaucine with indigo. Virchow, in 1847, was the next to record a blue urine in the case of a boy suffering from vesical pains and incontinence. In 1854 he (4) described the same blue pigment which he termed 'Harnblau' on adding mineral acid to the urine in a case of starvation. About the same time Gubler (5) found a blue pigment after the addition of nitric acid to the urine in cases of cholera, typhoid fever, smallpox scarlatina and acute nephritis. The mechanism of the production of indigo in the urine, however, still remained a mystery until Schunk (6), in 1857, expressed the opinion that the indigo blue substance which he also had found in the urine on boiling with mineral acids, was identical with the indicen obtained form such plants as the indigofera tinctoria, and isates tinctoria. Kletzinsky (7) proved the ldentity of Heller's uroglaucine with indigo. Schunk proved the identy of Heller's uroxanthine with indican.

Carter (8), In 1858 and 1859 , as a result of examination. of 300 cases, expressed the opinion that indican was a constant ingredient in human urine in health and aisease. In support of this finding, Schunk had also found indican in 39 out of 40 normal urines.

In 1863, Hoppe-seyler (9) demonstrated inaican in over 100 human urines and also in carnivora and herbivora. At this time he suggested that its formation was probably a function of the kidneys since in these organs only were traces of indican found after examination of spleen, liver. pancreas, mascles, blood and kianejs. 
Schunk had regaraed the indican of the urine as being of the nature of a glucoside, identical with vegetable indican. Baumann (10), however, proved that no sugar was formed in the decomposition of animal indican but that sulphuric acid and indol were formed. (Indol had been previously found by Nencki as a product of decomposition of indican). As a result of the subsequent work of Baumann, Brieger (11) and Thiemann (12) in 1879, animal indican was found to be composed of the conjugate sulphate of a hydroxylated indol with an alkali and was designated indoxyl sulphate. The term indican was confined to the indigo-yielding vegetable substance. By this time also Baeyer had demonstrated that indol was the mother substance of the entire indigo group. Radziewsky (13) had established the place of indol as a normal constituent of faeces in 1870 .

Jaffe (14), reviewing the evidenced culled from the findings of these various workers, was the first to formulate the conception that the indol, formed in the intestines, shoula be regarded as a source of urinary indican.

The subsequent experiments of Masson (15) in 1874 supported Jaffe's conception by showing that urinary indican in rabbits was increased by subcutaneous injection of indol. Jaffe,himself, confirmed this observation at a lates date. salkowski (16) then raised the point that the intestinal tract might not be the only source of the urinary indican but that the tissues also might represent a potential origin. Senator (17), however, in 1880, showed that the urine of newly borm infants contained no indican, a finalng which he attributed to the lact that no nourishment had been given by mouth and therefore no putrefactivel 
putrefactive organisms were present although putrefiable substances were present in the form of meconium. Some controversy then ensued around the question of the relationship of indicanuria to starvation. Salkowski, having found indican in the urine of dogs during starvation, was inclined to regard this evidence as supporting to his conception of the possible tissue origin of indican, since in those cases no food albumen was being given. Other contemporary workers, including Jaffe, however, pointed out that urinary indican was only: present in very small amounts in cases of starvation.

Tlegal and Billroth (18) and also Weiss (19) then submitted the view that the intestinal secretions, which according to Voit, contained 5.05 - $7.96 \%$ nitrogen, were a very probable source of indol under starvation conditions. Baumann then found that the administration of large doses of calomel to a dog was associated with the disappearance of all traces of indican from the urine. This effect was justifiably attributed to alsinfection of the intestinal tract thus proving finally the intestinal origin of indican and providing Iairly conclusire evidence against Salkowski's views.

In this connection simon (20) in his most valuable historical survey of this subject indicates that salkowskt: theorles, as to the tissue origin of indican, received a final blow by Baumann's work. Mile it is true that Salkowskl did regard the tissues as a likely secondary source of indican in the course of catabolic changes, and while in this particular respect, Baumann's evidence found him to be wrong, nevertheless subsequent work from Bamann's laboratory showed that resorption of decomposing pus in any part of the body was a source of indican additional to that 
of the intestine. Salkowski was therefore right in so far as the locus of the tissues were concerned. He was wrong only in so far as he regarded normal or increased tissue catabolic changes as against suppurative changes, as a source of urinary indican. Afain more recent workers have supported Salkowski's conception. Blumenthal and Rosenfeld (21) found that fasting rabbits eliminated urine rich in indican, while not a trace of indol was detected in the intestines. They (22) found further that when rabbits were poisoned with phlorhidizin, to the extent of causing tissue decomposition sufficient to induce an increased output of nitrogen in the urine, there was also an accompanying increased elimination of indican.

Harnock and Ienzin (23) found similar results when animals were poisoned with oxalic or sulphuric acid. Blumenthal and Rosenfeld then reiterated the theory of Salkowski that the indican of the urine might arise from tissue decomposition within the organism, entirely independent of the putrefactive processes of the integtine. Ellinger (24), however, repeated the work of Blumenthal and Rosenfeld, and found that if fasting rabbits were prevented from eating their own laeces; the urinary indican was either greatly diminished or disappeared. Ellinger considered that the method employed by Blumenthal and Rosenfeld for the detection of indol in the raeces had not been sufficiently delicate. The general evidence then veered back to the older view which regarded intestinal putrefaction as the cause of urinary indican. In pursuance of the experimental findings of Ellinger and Geutzen (25) which indicated that tryptophan was at least one of the precursors of indol and indican, Underh111 (26), in 1905, carried out an experimental study in which he fed dogs on successive periods/ 
periods of lean meat and gelatine and meat diets. The main objective was to determine the influence of gelatine as a nitrogenous food which does not contain a tryptophan group upon urinary indican. He found that gelatine reduced the quantity of indican excreted. Underhill's work showed then that not only the quantity of the nitrogenous constituent of the diet had an influence but that also that the quality of these substances plajed an important rôle in their bearing upon the excretion of indican. Sufficient evidence, that the indican of the urine was derived from indol formed by putrefaction of protein material within the lumen of the intestine, was thus gathered. Its presence in the isolated specimen of urine was not necessarily associated with disease. The significance of the presence of indican in the urine seemed to lie more in the frequenoy of its appearance and in its amount. It became evident, in the first place, that indicanuria showed a distinct periodicity in any given case. Interest naturally became centred around the factors which governed this pertodicity since such factors, were, at the same time, those which were apparently conducive to absorption of putrefactive products from the bowel.

Saxon (27), in 1926, called attention to the more or less tidal character of elimination of indican and indieated the necessity for examining each specimen in the twenty-four hours.

The next question which naturally arose was the site within the bowel from which the absorption was likely to occur. Jaffe (28) was the first to point out that diminished peristalsis in cases of a mechanical obstraction somewhere in the course of the small intestine was usually associated/ 
associated with an increased elimination of indican. The possible value of indican in cases of lleus was thus suggested by Jaffe. Furthermore Jaffe performed two experiments in one of wich the small intestine and in the other the large intestine were ligated. In the former, the amount of indican in the urine measured, in terms of indigo, increased, from 8 - $11.5 \mathrm{mgms}$. of ind 1 o in the urine before ligation and $76-88 \mathrm{mgms}$. of indigo in the urine from the second to the fifth days after ligation. In the case of the ligation of the large intestine at a point in the descending colon a very small amount of indican was found in the urine before Iigation, while after ligation the daily amount varied between 8 - $9 \mathrm{mgms}$. only. It seems fairly well established, therefore, that, according to simon (29), obstruction of the large intestine as well as disease of the large intestine in general, have been definitely shown to be unassociated with any marked increase in indicanuria and that, if the latter should be observed under such conditions, it may be inferred that there at the same timo alsease higher. up in the small intestine.

While Jaffe's classleal expeflifent revealed a marked increase in the amount of urinary indean when, under experimental conditions in the dog, the small intestine was ligated, his findings did not necessarily prove that the actual site of absorption of indol was from the portion of intestine above the ligature rather than from that below. As far as the site of absorption of putrefactive products from the bowel is concerned, it is a matter of common experience that when the small intestine is opened soon after death the contents are free from putrefactive odours. On opening the large intestine, nofker, putrefactive odours are marked. Furthermore/ 
Furthermore modern surgical experience tends to point to the fact that operations on the large intestine are nore frequently associated with local inflammatory and general toxic secuelee then it is upon the small intestine. It is now almost universeliy recoenised that, apart from obstructive lesions of the bowel, the large intestine is the sole source of absorption of putrefactive products.

The essence of the modern conception of indicanuria is that indoxyl potassium sulphate, a substance which has been proved to be derived from the indol produced by putrefaction within the large intestine, has been found to be present in the urine under varying conditions in health and in disease. The oxidetion from indor to indoxyl is supposed to take place in the liver.

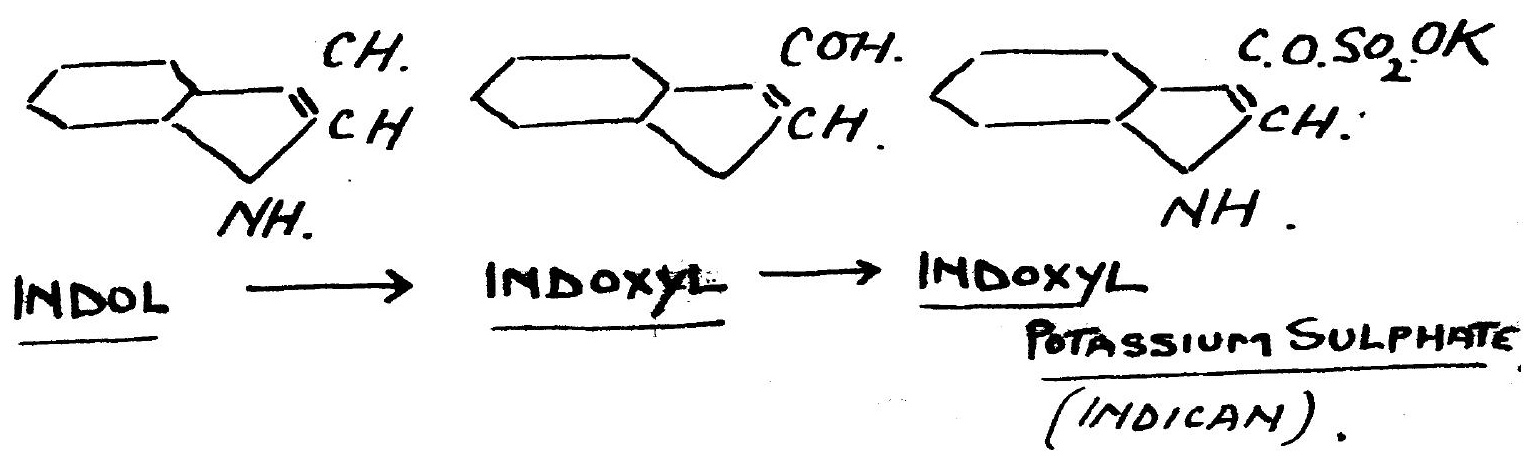

Its presence has been attributed, by various workers at various times, to the influence of excessive protein diet, to the presence of a predominantly proteolytic flora in the intestine, to various organic diseases of the intestine such as, carcinoma, obstructive lesions, typhoid and cholera, and to varlous functional disorders such as, atony and ptosis. Accumalated evidence, however, would seem to point to the fact that indicanuria cannot be regarded as being specifically diagnostic of any one of the aforementioned conditions. It would seem thet, since putrefaction is a process normal to the contents of the large intestine, the essential significance of indicanuria should be sought by ascertaining the particular/ 
particular states of intestinal function in terms of secretion novement and absorption, which are associated with the presence of this substance in the urine.

Since the presence of indicanuria in the urine is, in itself, evidence of absorption of indol from the bowel, the possible relationship of this absorbed indol or indiean to secretion, and to movement, within the bowel should help to provide a conception of the state of intestinal function In terms of secretion and movement under which indol is absorbed from the bowel. The following text has, therefore, been arranged under two headings:-

1. The relationship of indican to secretion.

2. The relationship of indican to movement.

\section{THE REIATIONSHIP OF INDICAN TO SECEETIOA.}

Along this particular channel of observation previous work has been directed chiefly towards the relationship between indicanuria and gastric secretion. The work of in 1895

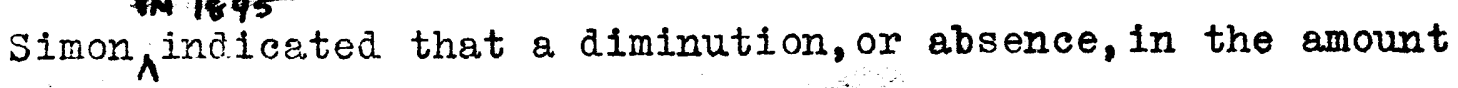
of free hydrochloric acid in the gastric contents was frequently associated with an increased amount of indican in the urine. In ninety-one cases of carcinoma of the stomach or bowel simon found in $76.93 \%$ of these cases an increased elimination of indican in the urine. In twenty cases of acute gastro-enteritis and three cases of hysterical anachlorhydria he found in $100 \%$ and $66 \%$ respectively of/ 
of these cases, an increased amount of indicanuria. Simon went so far as to conclude that it was permissible to regard the elimination of indican in the urine as an index of gastric acidity. He pointed out, however, that a normal amount of free $\mathrm{HCl}$. in the gastric contents was frequently associated with a normal amount of indican in the urine. Simon also mentioned a further point which rather tends to weaken his previous statement namely, that he had found cases of ulcer of the stomach to form an exception to the rale since, in these cases, an increased indicanuria was usually associated with hyperchlorhydria. In his cases of hyperchlorhydria, other than those of ulcer, he found a normal amount of indican in the urine. The following further statements concerning indicanuria are quoted from Simon's review on the subject which may be regarded as one of the most comprehensive treatises in the Iiterature. As premises to his conclusions he stipulates:-

"1. That a resorption of decomposing pus is not taking place

"anywhere in the body, as such a propses in 1 tself is " capable of producing an increased elimination of indican. "2. That there does not exist a stenosis of the small

" intestine.

n3. A normal mixed diet containing no excessive amounts of " red meat."

The salient points in his conclusions are:-

(a) "A subnormal amount of free hydrochloric acid will call "forth an increased degree of intestinal putrefaction."

(b) "A normal acidity of the gastrie fulce is never assoc"Iated with increased Indicanuria."

(c) "simple constipation is rarely accompanied by an increased "elimination of indican." 
(d) "Diarrhoea referable to a catarrhal condition of the "colon, often following a previously existing copros"tasis, as well as diseases of the colon in Eeneral, "is not associated with an increased indicanuria.

(e) "In the differential aiagnosis between ileus and "coprostasis, a small amount of indican excludes the "former condition."

As far as gastric secretion is concerned, Simon's findings certainly indicated that an excess of indican in the urine was more frequently associated with a diminution or absence of free hydrochloric acid than with a normal or excessive amount.

The relationship of indicanuria to pancreatic secretion has also been studied. In 1887, Pisenti (30) found, in a series of experiments on dogs, that the amount of indican in the urine is considerably diminished when pancreatic secretion is cut off. In these experiments it was observed however, that the urinary indican tended to show a initial increase immeciately after the cessation of flow of pancreatic juice and that it diminished rapidy thereafter. Pisenti has supported his experimental findings by indicating that the disappearanoe of indican in high fever is due to the fallure of pancreatic secretion. Observations, in connection with the pancreatic juice and the formation of indican, however, are not sufficiently numerous to be conclusive.

Mention is also made in the literature of a possible relationship between indicanuria and the secretion of bile. In 1895 Herter and Smith (31), quoting the studies of Ernst, stated that so long as the bile is present in the intestine It is possible to have indol formed in large amounts, probably because of the fact that the mucus of the bile furnishes/ 
furnishes material very favourable for certain kinds of putrefactive decomposition. These authors point out further that the latter observation is of special interest in connection with the circumstances in which catarrhal conditions of the small intestine are associated with the output of indican in pathological amounts. The foregoing evidence, although scanty, would suggest that as far as the relationship of the secretions entering the intestine, such as pancreatic juice and bile to indicanuria, is concerned the presence of the latter condition is associated more with the presence of these secretions in normal or excessive amounts rather than with their diminution or absence. 


\section{BIBIIOGRAPHY. (SECTION IV.A.)}

(1) WADSWORTH, W.S.: Indicanuria, Proc. Path., Soc. Phil., $1899,11,116$.

(2) PROUT, W.: Nature and treatment of stomach and urinary affections. 1840, 3rd. ed., 96. Iondon: Ibid. 1848, 5th ed., 567. Iondon.

(3) HEIIFR, : Archiv. fur physiol. und Pathol. chemi and microscop. 1845, 161 .

Ibid. 1844, 14 .

Ib1d. 1846, 19,536,539.

(4) VIRCHOW, : Arch. fur. Path. Anat. 1847, 1, 423. Ibid. vi, 259 .

(5) CUBIER, : Schmidt's Jahresb. 1859.

(6) SCHUNK, : Mem. of Iit. and Phil. Soc. of Manchester. $\mathrm{x} 1 \mathrm{~V}, 239$.

Phil. Mag. and Jour. of Sc., 4 th series, $x i v$, 288 .

Chem. Cbl. 1857, 957.

Jahresb. a. Them. 1855,659 .

Ibid. 1857,564 .

Ib1a. 1858,465 .

(7) KIEFZINSKY, : Wiener med. Woch., 1859, No.27. cited by Thualchum. Also in Pathology of Urine. 326.

(8) CARTER, : Eainburgh Medical Joü. July 1858, 1v, part 1, 86. 
(9) HOPPE-SFYLER, F.: Virchow's Archiv. 1863, xxv11, 383392.

(10) BAULINNN, : Ber. d. Deutsch. Chem. Gesellsch. ix, 54. Pflueger's Archiv. xil, 307. Zeit. f. physiol. Chemie, i, 60.

(II) BRIEGER, : Zeit. f. physiol. Chemie. iii, 254. Ber. der Deutsch. chem. Gesellsch. Xil, 2166.

(12) THIEMANN, : Ber. a. Deutsch. Chem Gesellsch. xil, 1098. Ibid. 1192 . Ibid. xiii, 408 .

(13) RADZIESKY, : Duboir-Reichert's Archiv. 1870, Heft.i.

(14) JAFFE, : Pflueger's archiv. 111, 448

(15) Masson, : 'Des Hatieres colorantes au point de vue physiologique. Dissertation, Berne. 1874.

(16) SATKOWSKI, : Ber. d. Deutsch. Chem Gesellsch. ix, 408. (17) SENATOR, : Zeit. f. physiol. Chem. 1880, iv, 1880.

(18) TIEGAT, \& BIITROTH: Virchow's Archiv. 1x, 453. (19) WEISS, : Virchow's Archiv. 1xx, 80.

(20) Sthion, C.E.: "The Moderm Aspect of Indicanuria." Amer. Jour. of the Medical Sciences. 1895, cx, 57. Philadelphia: Iea Bros. \& Co.

(21) BLULENTHAI, \& ROSEIFTID: Charite-Aunden. 1903, 46. 
(22) BLULENTHI, \& ROSEBFEID: Loc. Cit. also Lewin Bettragezar Chemischen Physialogil und Pathologie. 1902, i, 472.

(23) FARIOCK, \& V.A.IENZIN: Zeit. f. physiol. Chem. 1900, xxix, 205 .

(24) ELUINGER, : Zeit. f. physiol. Chem. 1903, xxxix, 44.

(25) ELIINGER, \& GEUTZEN: Beitrage zur chemischen Physiologie und Pathologie. 1903, iv, 171.

(26) UNDERHILI, F.P.: 'On the origin and precursors of urinary Indican.' Amer. Jour. Physiol. Book. 1904-5, xi1, $176-183$.

(27) SAXON, G.J.: 'Inaican its Periodicity of Rlimination.' Arch. of Pathol. and Laboratory Medicine: Nov. 1926, 796.

'Indican its Periodicity of Elimination.' Med. Clinics of North America. May 1927, No.6 1593.

(28) JAFHE, : 'The Modern Aspect of Indicanuria.' American Jour. of the Medical Sciences. 1895, ox, 166. Philadelphia: Iea Bros. \& Co.

(29) SIMON, C.E.: "The Hodern Aspect of Indicanuria". Amer. Hour. of the Medicel Sciences. 1895, cx, 165. Philadelphia: Lea Bros. \& Co. 
(30) PISENTI, : Ueber den Zusammenhang zwischen der Einwirkung des Pancreassaftes auf die Eiweisskorper und die Indicanmenge im Harm. Arch. per le scienze med. 1887, xif, No.5.

(31) HERTER, C.A. \& E.E.SMITH: 'Observations on Excessive Intestinal Putrefaction.' New, York Medical Jour. 1895, 1x1, 783 - 784. New York: D. Appleton \& Co. 


\section{SECTION IV.}

INDICANURIA.

B. EXPTRITINTS.

The experiments described in this section contain certain observations which I have made on the relationship of indicanuria to gastric secretion and to intestinal secretion and movement.

\section{EXPERIMENT XXIV.}

\section{TEE REIATIONSHIP OF INDICANURIA TO GASTRIC SECRETION.}

In the course of hospital and private practice during 1928 gastric analyses were done in 119 consecutive cases presenting gastric or intestinal symptons, such as would ordinarily warrant chemical investication. In each case, the urine was also examined for indican.

\section{Technique.}

Each patient was given the usual Ewald's test breakfast about $8 \mathrm{a.m}$. consisting of one slice of white bread with the crusts removed, toasted to a biscuit colour and eaten dry, together with $10-12$ ounces of freshly infused weat tea, containing neither sugar nor milk. The gastric contents were withdrawn one hour after this test meal by extraction through an Eswald's stomach tube. The contents were then filtered and $10 \mathrm{cos}$. of the filtrate were placed in a Weiss-tube, according to the technique described by MacLennan (1). $\Delta$ few arops of the double indicator of 
Iinossier* were added and the filtrate was subsequently titrated with the decinormal sodium hydrate solution, furnishing a quantitative estimation of free HCl. and total acidity.

The first specimen of urine passed on the morming of gastric analysis was examined for indican in each case. Obermeyer's.test for indican was employed throughout all the experiments in this section. This test was carried out as follows:-

3 ccs. approximately, of urine were placed in a test tube, to which an eques quantity of chloroform was subsequently added. The urine and the chloroform were thoroughly mixed by inverting repeatedly, the mouth of the tube being closed with the thumb. 6 ces. of Obermarer's reagent $f$ (i.e. approximately double the original amount of urine) were then added. The tube was again inverted frequently to promote a thorough mixing and then allowed to stand for 4 - 5 minutes. In this test, a positive reaction is indicated by the development of a blue colour in the chloroform layer due to the extraction of indigo-blue. The acid liberates/

Iinnossier's double indicator. Composition.

- Dimethylamidoazobenzol. .. $0.25 \mathrm{grm}$.

$\begin{array}{lr}\text { Phenolphthalein. } & \text {. I20 } \mathrm{grm} . \\ \text { Alcohol. (90\%). } & \text { I00 } \mathrm{grm} .\end{array}$

+ Obermayer's Reagent. Composition.

Ferric. chloride. 4 grms.

Hyarochloric Acid. cone. IOOO c.c. 
liberates indoxyl from potassium indoxyl sulphate (indican); the indoxyl is oxidised to indigo-blue by the ferric chloride which is present in Obermager's reagent as a mild oxidising agent.

Accordine to Harrison ( 2 ) and others the depth of the blue colour in the chloroform layer gives e rough measure of the quantity of indican present. A deep blue colour is indicative of an increased amount of indican. A negative reaction is indicated by a colourless chloroform layer.

The results are recorded in tables 30,31 , and 32.

The cases have been place in three groups according to the percentage of Iree HCl. present in the gastric. contents in each case:-

Group I. Cases of gastric acidity within normal range. Group II. Cases of hypochlorhydria and achlorhydria. Group III. Cases of hyperchlorhydria.

A strong indican reaction 18 represented by ++ .

A distinctly positive, although lighter blue colour, reaction is represented by + .

1 weak positive reaction is represented by + (weak).

$\Delta$ negative reaction is represented by -

\section{TABIE 30/}


TAble 30

CASES OF GASTRIC ACIDITY WITHIN NORUAI RANGE.

\begin{tabular}{|c|c|c|c|}
\hline \multirow{2}{*}{ CASE. } & GASTRIC & CONTENTS & \multirow{2}{*}{ INDICAN } \\
\hline & Free HCl. & Total Acidit & \\
\hline 1. & $\begin{array}{c}\text { PER CENT } \\
0.16\end{array}$ & $\begin{array}{l}\text { UN1TS } \\
50\end{array}$ & ++ \\
\hline 2. & 0.13 & 45 & 一 \\
\hline 3. & 0.16 & 50 & + \\
\hline 4. & 0.15 & yo & + \\
\hline 5. & 0.13 & 50 & - \\
\hline 6. & 0.14 & 50 & + \\
\hline$y$ & 0.14 & 60 & + \\
\hline 8. & 0.16 & 55 & + \\
\hline 9. & 0.13 & So & - \\
\hline 10. & 0.14 & 55 & - \\
\hline 11. & 0.134 & 50 & - \\
\hline 12. & 0.13 & 60 & - \\
\hline 13. & 0.18 & 55 & - \\
\hline 14. & 0.144 & 40 & - \\
\hline 15. & 0.1 & 45 & + \\
\hline 16. & 0.14 & 50 & - \\
\hline Iy. & 0.144 & 50 & + \\
\hline 18. & 0.18 & 55 & - \\
\hline 19. & 0.18 & 50 & + \\
\hline
\end{tabular}




\section{Table 31}

CASES UF HYPOCILORHYDIA AND ACEIORTDRIA.

\begin{tabular}{|c|c|c|c|}
\hline \multirow{2}{*}{$\checkmark A S E$} & \multicolumn{2}{|c|}{ GASTRIC CONTENTS } & \multirow{2}{*}{ INDICA: } \\
\hline & Free HCl. & Total Acidity & \\
\hline 1. & $\begin{array}{c}\text { PER CENT } \\
0 .\end{array}$ & $\begin{array}{l}\text { UNITS } \\
20\end{array}$ & ++ \\
\hline 2. & 0. & 10 & ++ \\
\hline 3. & 0. & 10 & + \\
\hline 4. & 0018 & 20 & + \\
\hline 5. & 0. & 10 & + \\
\hline 6. & 0. & 20 & + \\
\hline$y$ & 0. & 0 & ++ \\
\hline 8. & 0. & 30 & ++ \\
\hline 9. & 0.009 & 20 & + \\
\hline 10. & 0. & 10 & + \\
\hline 11 & 0.003 & 25 & + \\
\hline 12. & 0.054 & 100 & + \\
\hline 13. & 0.018 & 10 & + \\
\hline 14. & 0. & 5 & - \\
\hline 15. & 0. & 10 & - \\
\hline 16. & $0.0 y 2$ & 45 & - \\
\hline $1 y$ & 0. & 5 & - \\
\hline 18. & 0. & 10 & - \\
\hline 19. & 0. & 5 & + \\
\hline 20. & 0. & 8 & + \\
\hline 2. & 0. & 5 & - \\
\hline 22. & 0. & 0 & ++ \\
\hline 23. & 0. & 10 & + \\
\hline $2 k$. & 0. & 0 & - \\
\hline $26^{\circ}$ & 0. & 5 & + \\
\hline 26. & 0. & 5 & $+(\operatorname{sight})$ \\
\hline $\pm y$ & 0. & 10 & - \\
\hline 28. & 0. & 30 & $+($ slight $)$ \\
\hline 29. & 0. & 35 & - \\
\hline 30. & 0.054 & 15 & - \\
\hline 31. & 0. & 20 & $+t$ \\
\hline 32. & 0.042 & yo & - \\
\hline 38. & 0. & 20 & + \\
\hline 34. & 0. & 20 & + \\
\hline 35. & 0.09 & 35 & + \\
\hline
\end{tabular}


TABLE. 32.

CAUAS OF ITPURCILORTIDRIA.

\begin{tabular}{|c|c|c|c|}
\hline \multirow{2}{*}{ S.LA S } & \multicolumn{2}{|c|}{ GASTRIC CUNTENTS } & \multirow{2}{*}{ INDICAN } \\
\hline & Free HCl. & Total Aciōity & \\
\hline 1. & $\begin{array}{c}\text { PER CENT } \\
0.32\end{array}$ & $\begin{array}{l}\text { UNITS. } \\
100\end{array}$ & ++ \\
\hline 2. & 0.25 & $1 / 5$ & + \\
\hline 3. & 0.234 & y5 & + \\
\hline 4. & 0.2 & $65=$ & + \\
\hline 5. & 0.2 & yo & + \\
\hline 6. & 0.214 & 86 & $t$ \\
\hline$y$ & 0.32 & 110 & ++ \\
\hline 8. & 0.3 & 95 & + \\
\hline 9. & 0.216 & yo & + \\
\hline 10. & 0.3 & 95 & ++ \\
\hline 11. & 0.234 & yo & ++ \\
\hline 12. & 0.25 & 80 & $t$ \\
\hline 13. & 0.25 & 85 & $t+$ \\
\hline 14. & 0.216 & yo & + \\
\hline 15. & 0.3 & 110 & \pm \\
\hline 16. & 0.2 & 65 & + \\
\hline Iy. & 0.3 & $95^{\circ}$ & + \\
\hline 18. & 0.25 & 95 & + \\
\hline 19. & 0.3 & 110 & $+t$ \\
\hline 20. & 0.215 & yo & + \\
\hline 21. & 0.3 & 100 & - \\
\hline 29. & 0.3 & 95 & - \\
\hline 23. & 0.234 & 45 & - \\
\hline 24. & 0.234 & 45 & - \\
\hline 25. & 0.216 & yo & - \\
\hline 26. & $0.2 y$ & 85 & - \\
\hline $2 y$. & 0.3 & 90 & - \\
\hline 28. & 0.216 & yo & - \\
\hline 29. & 0.25 & 80 & - \\
\hline 30. & $0.2 y$ & 85 & - \\
\hline 31. & 0.216 & 80 & - \\
\hline 32. & 0.2 & 60 & - \\
\hline 35. & 0.25 & yo & - \\
\hline 34. & 0.234 & $15^{-}$ & - \\
\hline
\end{tabular}


TABLe 32. (COMtinued)

OANSS OF HYPLRC:IOREYDEIA.

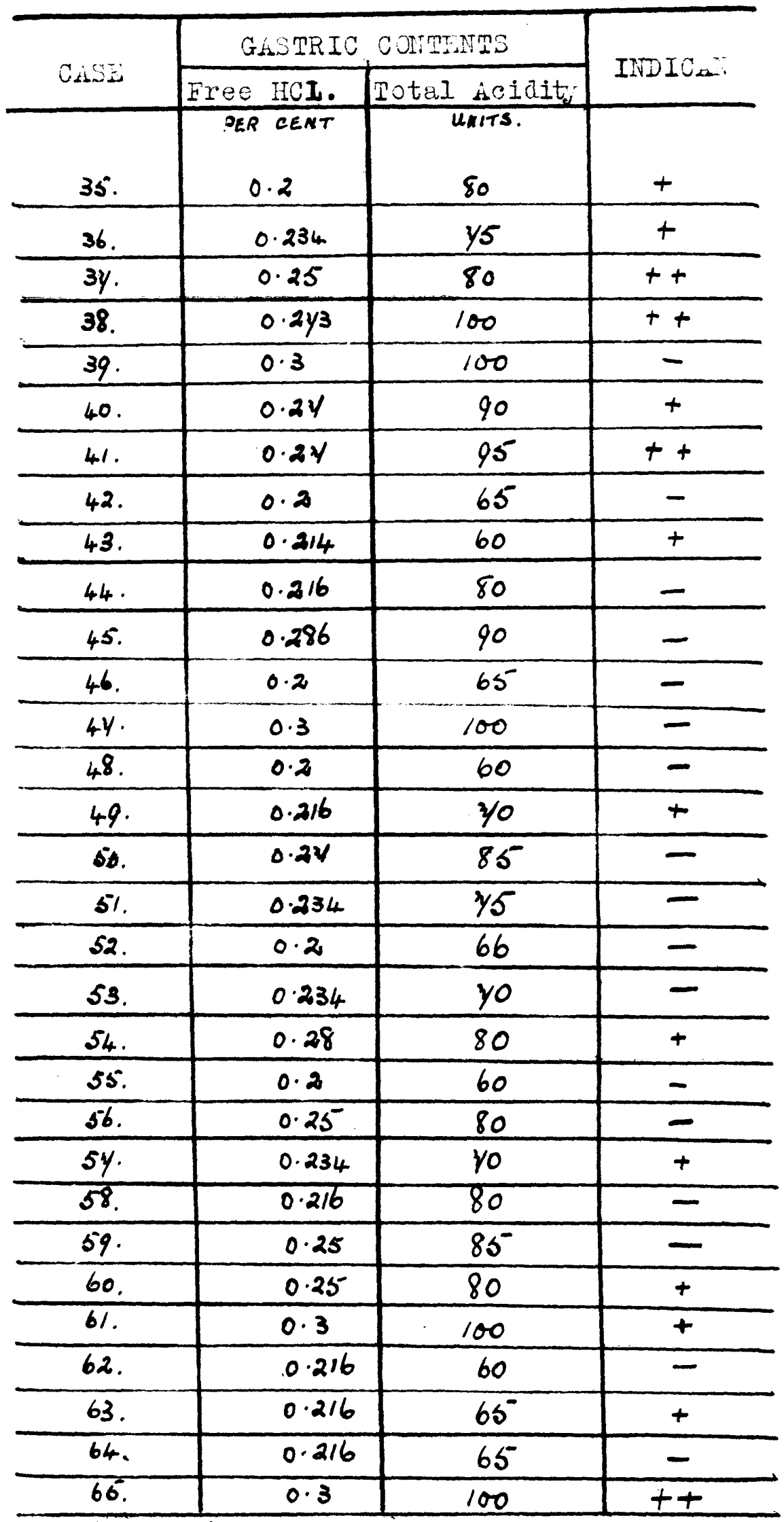


The percentagew, under the various groups, in which indican was found in the morning specimen of urine are represented in table 30 .

TABIE 33.

\begin{tabular}{|c|c|c|c|}
\hline تRIOUL & $\begin{array}{l}\text { To. } \\
\text { Cases }\end{array}$ & 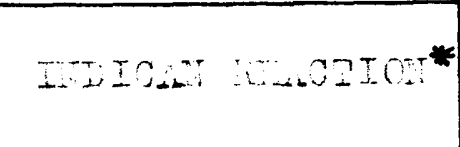 & $\begin{array}{l}\text { PIRCFNTAGE } \\
\text { rith } \\
\text { IVICANURIA }\end{array}$ \\
\hline I & 19. & $\begin{array}{l}\text { MNICAY + } 9 \\
\text { IMOICAY, } 10\end{array}$ & $\begin{array}{l}47 \cdot 4 \\
52 \cdot 5\end{array}$ \\
\hline $\begin{array}{l}\text { II } \\
\text { HYPOCALORMYORIA } \\
\text { ACHLORHYORIA }\end{array}$ & 35. & $\begin{array}{l}\text { INDICAN+ } 26 ! \\
\text { IMDICAN - } 11\end{array}$ & $\begin{array}{l}68 \cdot 6 \\
3 / \cdot 4\end{array}$ \\
\hline HYPERCHLORAYORIA & 65 & $\begin{array}{l}\text { IMOICAM + } 34 \\
\text { IMOICAM - } 31\end{array}$ & $\begin{array}{l}5 z \cdot 3 \\
47 \cdot 7\end{array}$ \\
\hline
\end{tabular}

Comments on Tables $30,31,32$, and 33 .

A survey of the above tables reveals the following points:-

In Group I. the percentages of positive and of negative indican reactions are almost equal.

In Group II. the percentage of positive inaican reactions is double that of the negative indican reactions. In Group III. the percentages of positive and of negative indican reactions are almost equal.

While a marked predominance of positive reactions $(68.6 \%)$ is associated with the 35 cases of diminished or absent/

* All positive reactions, strone, meclum or weak are included as $t$ in this column. 
absent gastric secretion in Group II., positive reactions are elso associated with the 19 cases of normal range gastric secretion to the extent of $47.4 \%$ and with the 65 cases of excessive gastric secretion to the extent of $52.3 \%$.

\section{Discussion of Results in Experiment XXIV.}

These results would tend to negafy Simon's statement previously quoted (page $/ \% / 4$ ) to the effect that the elimination of indican in the urine may be regarded as an index of free hydrochloric acid present in the gastric contents. In the above experiment strongly positive indican reactions were found to be associated with cases of achlorhydria, hypochlorhyaria, and of hyperchlorhydria.

The evidence would seem to point to the fact that no distinct relationship can be established between the indican reaction of the urine and the amount of free hydrochloric acid present in the gastric contents.

\section{EXPER IMENTS XXV and XXVI.}

\section{THE PERIODICITY OF INDICANURIA.}

As a result of the routine examination of urines for indican in private patients during 1928, certain cases, giving positive reactions, were selected for special observation. In these seleoted cases, every specimen of urine passed in the 24 hours was tested for indican over periods varying from 14 - 16 days, in order tol 
- to determine whether the presence of indican in the urine, in any given case, was a constant or a periodical phenomenon.

\section{EXPER IMENT XXV.}

The subject of this experiment was a married woman aged 32 years, suffering from extreme visceroptosis. Gastric analysis revealed achlorhydria associated with poorly digested contents and an excessive amount of mucus. The patient was confined to bed. The observations were carried out while she was under treatment in a nursing-home. The diet, which is not regarded as one of the experimental data, consisted of three light meals per duem., eaten dry with fluids, such as milk, whey and buttermilk in the intervals. Every specimen of urine passed, in the course of 24 hours, was examined qualitatively for indican by obermyer's test. The results are recorded in table 34. A strongly positive indican reaction is represented by a large size $t$. A distinctly positive, although lighter blue colour reaction, is represented by + (half the size of the former). A negative reaction is represented by - - Defaecation is represented by the letter "B." 
THE PERIODICITY OF IMOICAMURIA.

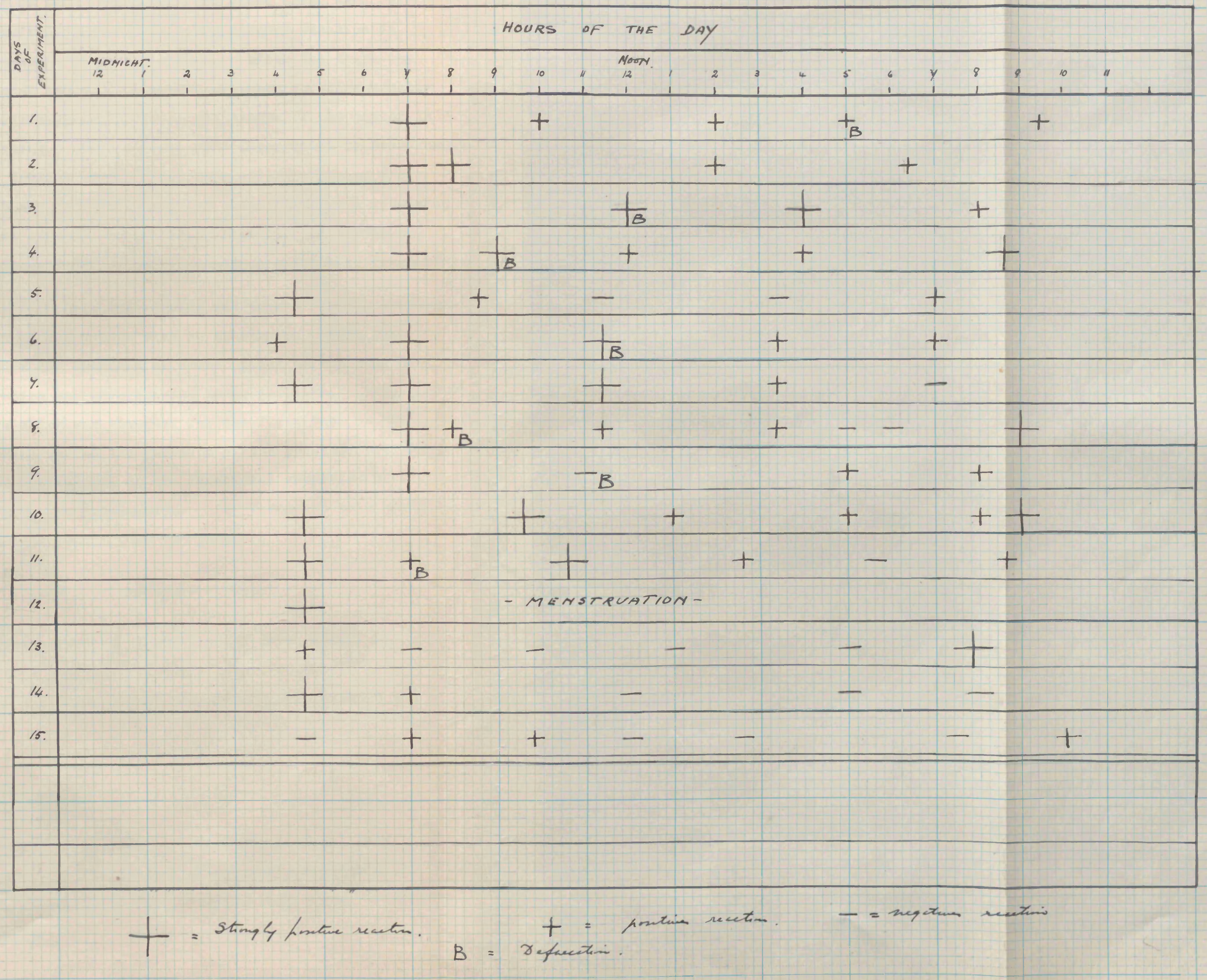


Descriptive Comments on Table 34 .

It is seen that during the first three days, only positive reactions occur. The mornine reaction is consistently strongly positive. After the third day, occasional negative reactions are seen to occur, usually in specimens passed towards the midale of the day or in the morning. Observations were interrupted by menstruation on the twelfth day. Three days elapsed between the twelfth and thirteenth days of observation, when specimens of urine were not collected. From the thirteenth to the fifteenth day negative reactions occur more frequently.

In this case, indicanuria was seen to show a tendency to periodicity rather than to constancy. With one exception, the specimen of urine passed at the time of defaecation was always found to be positive. This latter feature, which was observed for the first time, in this experiment raised the question of the possible relationship of Indicanuria to the functional condition of the bowel prior to defaecation. The faeces in this instance were usually pultaceous or fluid.

Examination of other patients over similar periods revealed a similar tendency to the periodicity rather than to the constancy of indicanuria, in any given case.

\section{EXPER IMGMT TXVI.}

The observations, in this instance, were carried out upon myself. The period of observation was 36 days. I have recorded the first eighteen days only, since they 
, exemplify the entire period. Throughout this time health was good with freedom from any symptoms. The analysis of my gastric contents, ( 1 hour after an Ewald's test meal), which I had ascertained a lew weeks prior to this experiment, revealed a degree of hyperchlorhydria. The daily routine included the usual commitments of hospital and private practice and it was more or less constant throughout, as regards work output. Each specimen of urine, passed in the course of 24 hours was examined qualitatively for indican by Obermeyer's test over a period of 36 days. The faeces were well formed throughout. The results are recordec In table 35. The same signs indioating indican reaction are used as in table 34 .

\section{TABIE 35.1}


EXPERIMENT XXVI

THE PERIODICITY
TABLE 35.

OF IMDICAMURIA
AMD ITS RELATIONSHIP TO DEFAECATION.

HOURS OF THE DAY

\begin{tabular}{|c|c|c|c|c|c|c|c|c|c|c|c|c|c|c|c|c|c|c|c|}
\hline & & & & & & & & HOURS & OF THEDA & & & & & & & & & & \\
\hline & 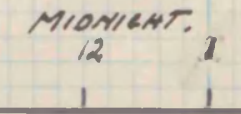 & 2 & 3 & 4 & 5 & $\begin{array}{l}6 \quad y \\
\end{array}$ & 8 & $9 \quad 10$ & 1 Noon. & 2 & 3 & i & 5 & 6 & y & 8 & $?$ & 10 & : \\
\hline 1. & & & & & & & - & $t_{B}$ & - & - & & + & & - & & & + & & \\
\hline 2. & & & & & & & + & $t_{B}$ & + & & + & & + & & & & + & & + \\
\hline 3. & & & & & & & + & $t_{B}$ & + & & & & & & & & - & & - \\
\hline 4. & & & & & & & - & $+_{B}$ & - & & - & & - & & - & & & - & - \\
\hline 5. & & & & & & & - & $+{ }_{B}$. & - & & & - & & - & & & & - & 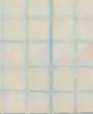 \\
\hline 6. & & & & & & & - & $t_{B}$ & + & & & & & & - & & & & - \\
\hline 4. & & & & & & & - & $+_{B}$ & + & & + & & & & - & & & & H \\
\hline 8. & + & & - & 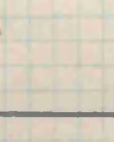 & & & + & $t_{B}$ & + & & & + & & & - & & & & 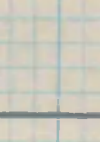 \\
\hline 9. & & & & & & & - & & $t_{B}$ & & + & & & & + & + & - & & - \\
\hline 10. & & & & & & & - & $B$ & + & & & & & & - & & & & 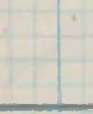 \\
\hline 11. & & & & & & & + & $+_{B}$ & + & & & - & & & - & & & - & - \\
\hline 12 & - & & & & & & - & $t_{B}$ & - & - & & & & 8 & - & & - & & - \\
\hline 13. & & & & & & & - & $-B$ & - & & & 1 & & - & & & & - & \\
\hline 14. & & & & & & & + & $-B$ & $t$ & & & - & & & - & -1 & $B$ & & \\
\hline 15. & & & & & & + & & - & 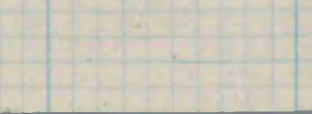 & & & & & - & the & + & + & & \\
\hline 16. & + & & & & & & & $+-B$ & $t_{B}$ & & & - & & & & - & & & - \\
\hline 17. & & & & & & & & $--_{B}$ & - & & & & & - & & & & + & \\
\hline 18. & & & & & & + & & & + & & + & - & & & - & - & & - & \\
\hline
\end{tabular}




\section{Descriptive Comments on Table 35.}

With the exception of the second day, on which all the reactions are positive, it is seen that negative and positive reactions are distributed throughout all the other days. From the fourth day onwards, the negative reactions tend to predominate. The association of positive reactions with the times of defaecation occur regularly, with the exception of the IOth, I3th, I6th and I7th days.

\section{Discussion of Results in Experiments XXV \& XXVI.}

The results recorded in tables 34 and 35 represent the daily incidence of indicanuria, which is periodical rather than constant, over periods of I4 to I6 days. At the same time, these results may be taken to represent the daily inciaence of absorption of indol from the intestine. It is from this latter point of view that the results are of interest. The absorption of indol, therefore, is associated with periodicity rather than with constancy in the course of the average day.

\section{The association of a positive indican reaction with} the time of defaecation suggests a possible relationship of the absorption of indol from the intestine to a period $\lambda$ of increased intestinal morement.

On page I39. (sect. III.A.) one of the facts which I extracted from the work of Cathcart and Ieathes, is quoted: Absorption from the intestine was proved, associated with movement. Secretion was not ascertained." The results/

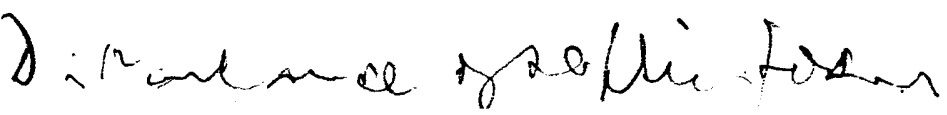


results of Experiments XXV and XXVI. tend to support, qualitatively, those findings from experiments on dogs.

In Experiments XXV and XXVI, also, absorption from the intestine, as evidenced by indicanuria, was proved, associated with movement, as evidenced by defaecation.

EXPER IMENT\&\&XXVII.

THE REIATIONSHIP OF IMDICANURIA TO INTESTINAL SECRETION ALD MOVEMENT\&

In view of the results obtained in the preceding experiments, it was decided to observe the incidence of indicanuria before and after experimental stimulation of intestinal secretion and movement.

As previously mentioned on page I25.( sect. III.A.) the experiments of Noreau, Lauder Brunton and Pye-Smith on animals, proved that magnesium sulphate, when injected into a loop of intestine, caused a resultant increase of secretion within the particular loop. In the following experiment, magnesium sulphate was selected as a suitable stimulant of intestinal secretion.

Technique.

In the course of hospital and private practice, during I930 and I93I, one hundred patients were selectod, irrespective of their particular diseases, as subjects of this experiment. The only basis of selection stipulated, was the absence of any contra indication to the oral administration of an adequate dose of magnesium sulphate. Both out patients and in patients 
in patients were included in this group. Each patient was given a two drachm dose of Epsom salts in the morning. The last specimen of urine on the preceding evening, the first specimen next morning, before the saline, and the three successive specimens after the saline were collected and examined for indican by Obermayer $s$ test. Fach patient was carefully instructed to save the specimen of urine passed at the time of defaecation, since this specimen was usually the first to be passed after taking the saline.

In the cases of out patients, the following written instructions were supplied:

I. Collect the last specimen of your urine at night.

2. Collect the first specimen after waking, in the morning.

3. Then take two teaspoonfuls of Epsom salts in water.

4. Thereatter, collect the next three specimens of urine, notine carefully the time of each specinen. Wark the hour of passing on each specimen. Nark the letter $B$. on the specfmen of urine passed at the time of the movement of the bowels.

Each out patient was supplied with five $\frac{1}{2}$ oz. bottles with corks. In the cases of in patients, specimens were collected in the course of ward routine.

On reporting with the collected specimens, each out patient was interrogated as to the consistence of the first faeces passed, after taking the dose of Epsom salts. The times of passing of the various specimens were also confirmed.

No attempt was made to control either the diets or the daily routines of the selected patients. The results of this experiment are recorded on Table 36. The diagnosis is given in each case, merely to show 
show the diversity of cases examined. The same signs pertaining to indican reactions and defaecation are given as in Tables 34 and 35 . Bf. pepesserrs A FLuD sto.L. Table 36 occupies 3 separate sheets.

\author{
TABIS 36./
}




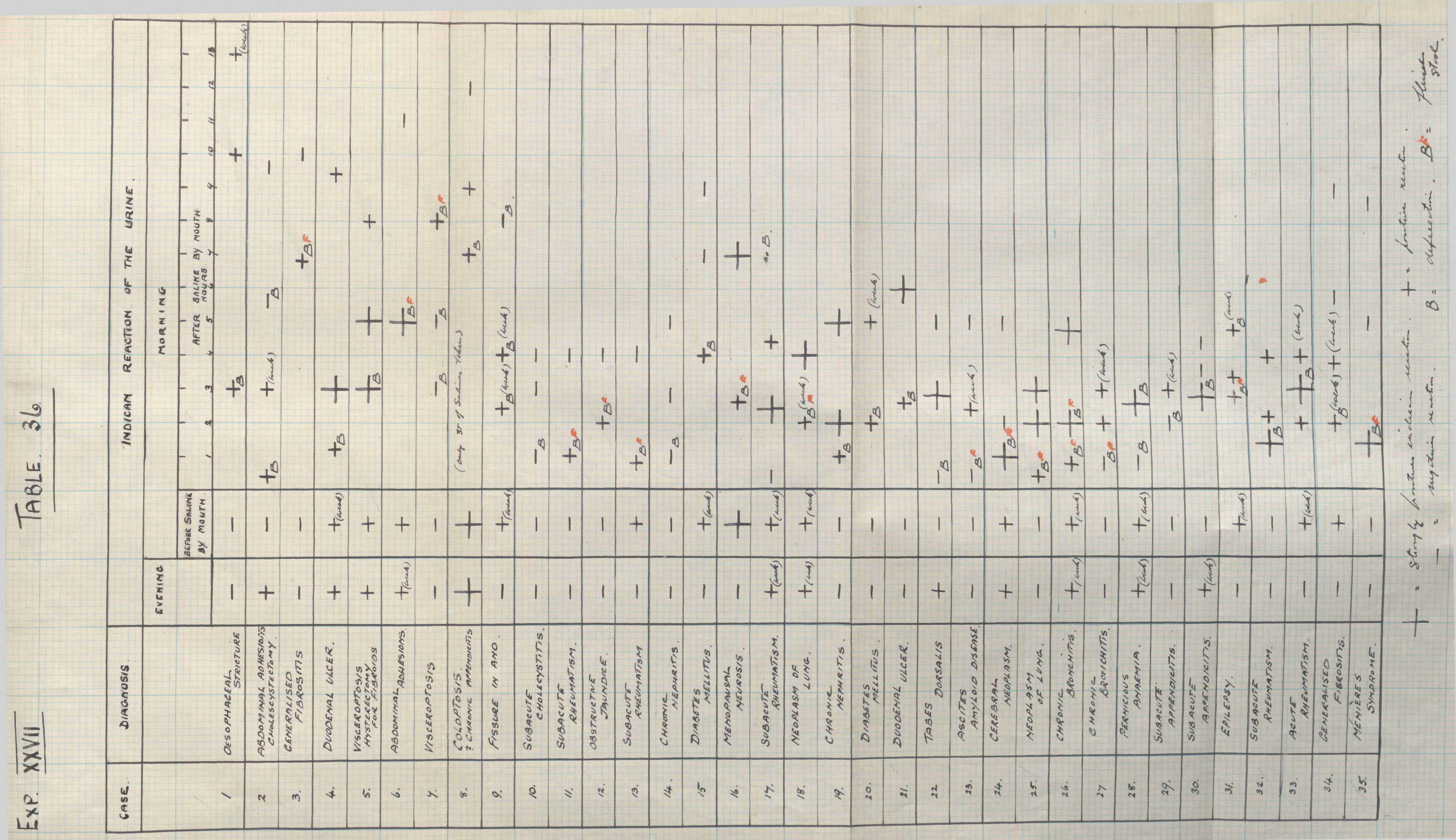




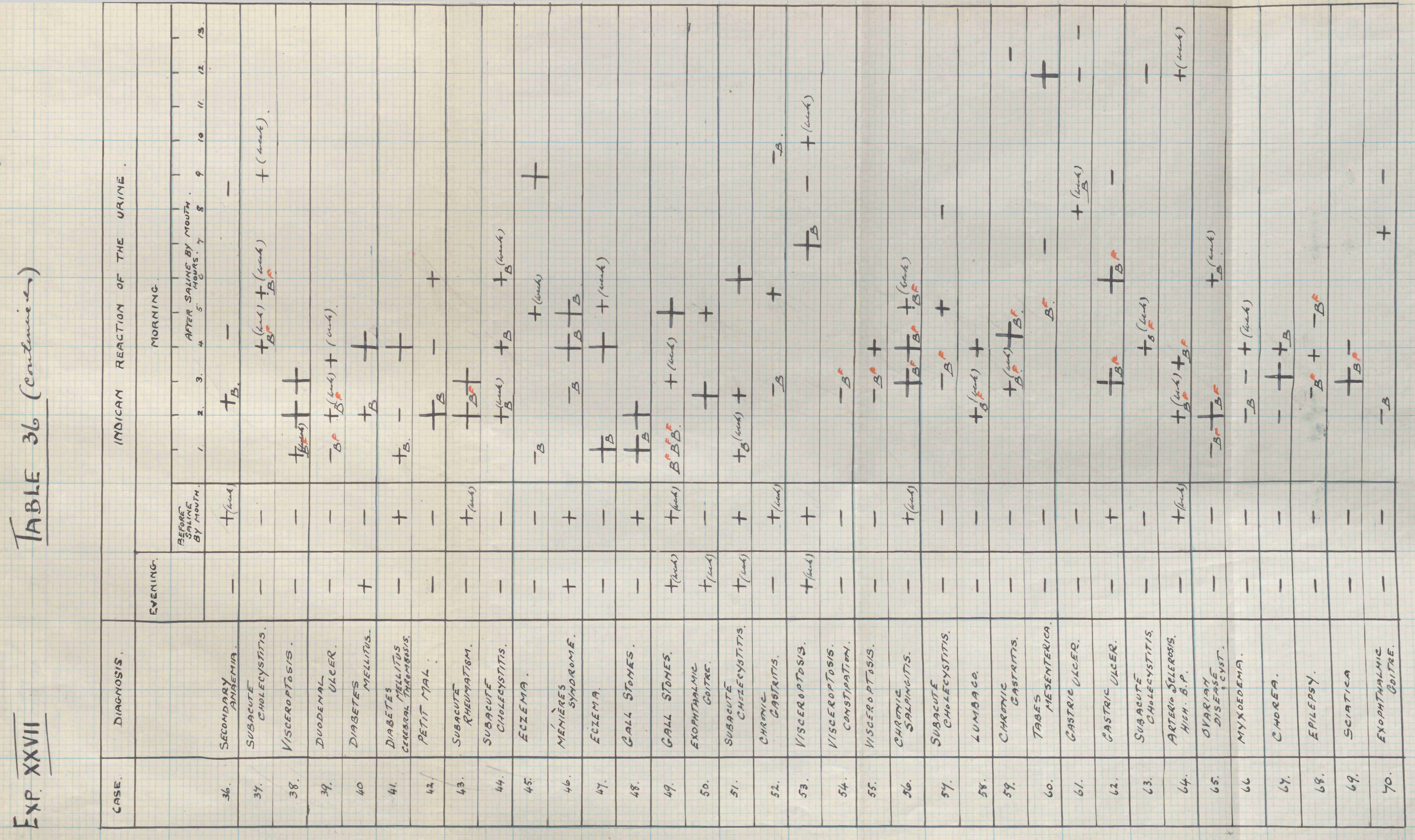




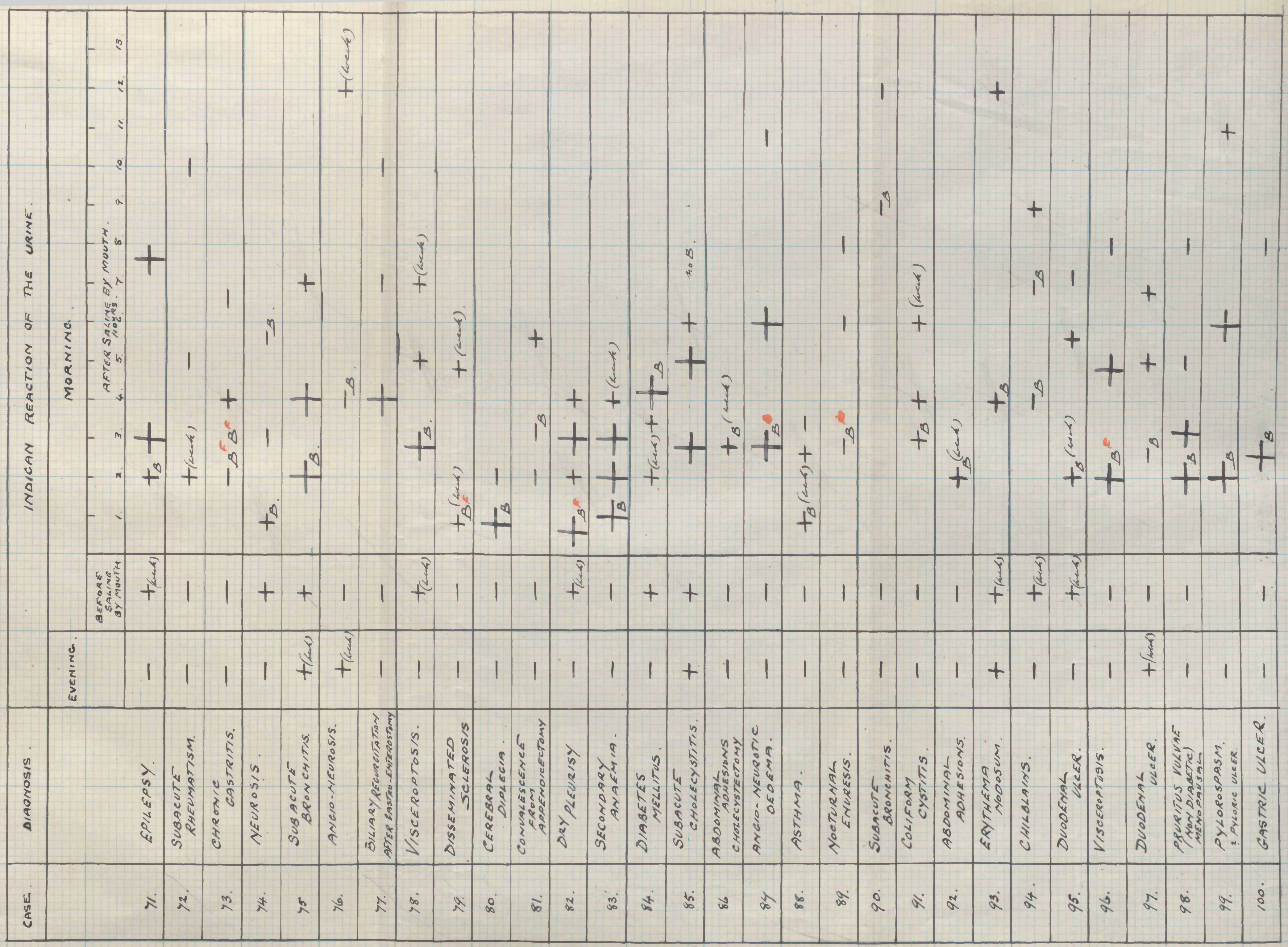


Descriptive Comments on Table 36.

A survey of the above table reveals a distinct increase in the incidence of indicanuria in the period following the dose of the saline of magnesium sulphate by mouth. Proof of the fact that stimulation of intestinal secretion was effected in these cases, is definitely indicated by the presence of fluid rather than formed faeces, in many instances The faeces were not inspected in each case but it was ascertained from the patient whether or not the response to the saline had been such as to indicate an effect on either the usual time or frequency of daily defaecation or on the consistence of the faeces. With the exception of cases $17,50,72 \& 85$ in which it is seen that no defaecation took place during the period of observation, a definite response to the saline was indicated in all cases.

In testing the urines in the course of this experiment, the tendency to positive indican reactions in the specimens of and spassed with defaecation in the first specimen passed thereafter, was certainly noteworthy.

The incidence of indicanuria expressed in percentage of positive reactions, before and after the saline, is recorded in table 37 . 
TABIE 37.

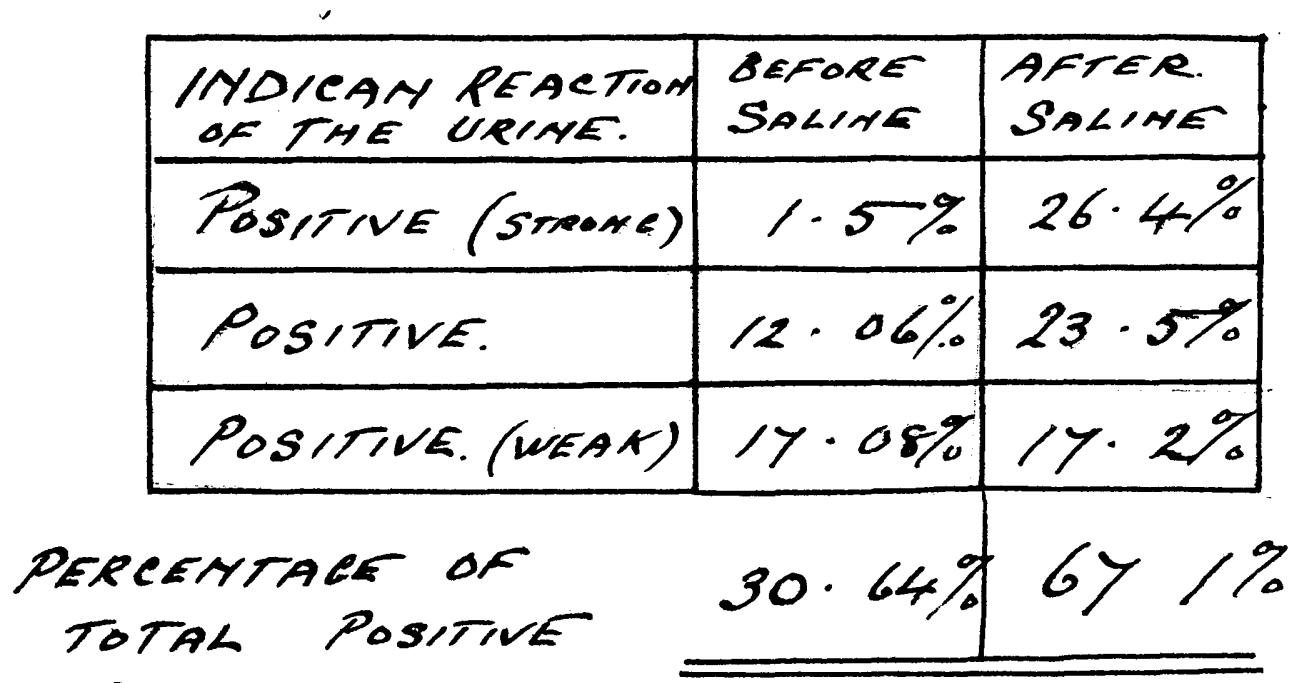
PEACTIONS.

\section{Discussion of Results in Experiment XXVII.}

In one hundred petients, 471 isolated individual specimens of urine were tested for indican. Of this number, 199 represented specimens passed within a period of 12 hours before the administration of two drachms of magnesium sulphate by mouth and 272 represented the specimens passed within a period of 12 hours after administration of the magnesium sulphate by mouth. The total positive indican reactions in the specimens passed before the saline amounted to $30.64 \%$. The total positive indican reactions in the specimens passed after the saline amounted to $67.1 \%$. 
In the cases recorded, in increase in the incidence of indicanuria is seen to be associated with the administration of two drachms of magnesium sulphate by mouth.

It was ascertained that, with the exception of cases 17, 50, $72 \& 85$, the administration of this dose of magnesium sulphate was followed, in each case, by a definite effect upon either the usual time or frequency of defaecation or the consistence of the faeces. Stimulation of intestinal secretion and movement was therefore justifiably indicated.

An increase in the incidence of indicanuria is, therefore, seen to be associated with a period in which there is an increase in secretion and in movement within the intestine.

CONCLUSION

THE $\triangle B S O R P T I O N$ OF INDOI FROM THE INTESTINE IS ASSOCIATEA WITH AN INCREASE IN SECRETION AND MOVEMENT WITHIN THE INTESTINE. 


\section{BIBLIOGRAPHY. (SECTIOA IV.B.)}

(1) Machennan, W.: A Manual of Diseases of the Stomach. 1921, 122. London: Edward Arnold \& Co.

(2) HARRISON, G.A.: Chemical Methods in Clinical Medicine. 1930, 20. Iondon: J. \& A. Churchill. 